University of Chicago Law School

Chicago Unbound

Journal Articles

Faculty Scholarship

1995

\title{
Cooperation and Conflict: The Economics of Group Status Production and Race Discrimination
}

Richard H. McAdams

Follow this and additional works at: https://chicagounbound.uchicago.edu/journal_articles

Part of the Law Commons

\section{Recommended Citation}

Richard H. McAdams, "Cooperation and Conflict: The Economics of Group Status Production and Race Discrimination," 108 Harvard Law Review 1003 (1995).

This Article is brought to you for free and open access by the Faculty Scholarship at Chicago Unbound. It has been accepted for inclusion in Journal Articles by an authorized administrator of Chicago Unbound. For more information, please contact unbound@law.uchicago.edu. 


\title{
COOPERATION AND CONFLICT: THE ECONOMICS OF GROUP STATUS PRODUCTION AND RACE DISCRIMINATION
}

\author{
Richard H. McAdams
}

\section{TABLE OF CONTENTS}

I. Explaining "Excess" Cooperation and Conflict: An Economic

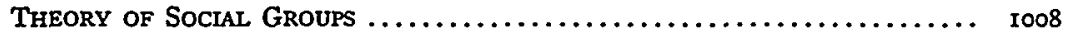

A. The Empirical Evidence of "Excess" Cooperation................. roog

I. Dilemma Experiments: Evidence of Non-Material Motivations for

Cooperation ...................................... IoI

2. Dilemma Experiments: Evidence of Non-Altruistic Motivations for

Cooperation ................................... 1013

3. Cooperation Outside the Laboratory: Further Evidence That Groups

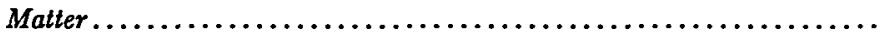

B. Economic Explanations of "Excess" Cooperation:

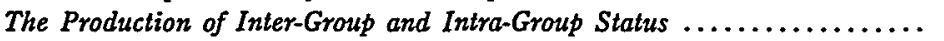

r. The Individual Preference for Esteem and Status ...............

2. Members of "Shared-Trait" Groups Cooperate to Produce Inter-Group

Status ...................................... I02 I

3. Members of "Socially Connected" Groups Cooperate to Produce Intra-

Group Status ................................ 1023

C. The Consequences of Intra-Group Cooperation:

Inter-Group Confict

I0I7

I019

I0I9

1029

I033

A. Empirical Failures of the Associational

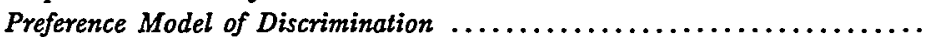

I. Overinclusiveness: The Prevailing Model Overpredicts Discrimination...

2. Underinclusiveness: The Prevailing Model Underpredicts

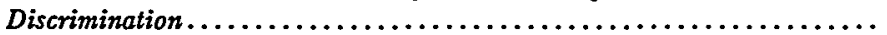

1036

ro39

3. Efforts to Preserve the Model Are Inconsistent With Economic

Reductionism ................................... 1042

B. The Status-Production Model of Race Discrimination............... 1044

1. The Economics of Racial Status Production ................... 1045

(a) Overcoming the Free-Rider Problem .................... I046

(b) Mechanics for Lowering a Group's Status .................. I048

2. The Explanatory Power of the Status-Production Model ............ I049

(a) Using Status Production to Explain the Jim Crow South ......... I049

(b) Using Status Production to Explain Who Discriminates.......... 1053

(c) Using Status Production to Explain Racial Beliefs ............ ro56

C. Implications of the Status-Production Model of Discrimination .......... I063

I. The Persistence of Race Discrimination..................... 1063

(a) The Stability of Discriminatory Norms ................... 1064

(b) Reciprocity as a Basis for Market Discrimination ............. 107x

(c) The Power of Esteem-Producing Racial Biases .............. I072

2. The Efficiency of Anti-Discrimination Laws ................. I074 
(a) Discrimination as Market Failure: The Theft Analogy .......... 1074

(b) An Efficiency Argument for Anti-Discrimination Laws ......... 1078

III. Conchusion $\ldots \ldots \ldots \ldots \ldots \ldots \ldots \ldots \ldots \ldots \ldots \ldots \ldots \ldots \ldots \ldots \ldots \ldots \ldots \ldots \ldots \ldots$ 


\title{
COOPERATION AND CONFLICT: THE ECONOMICS OF GROUP STATUS PRODUCTION AND RACE DISCRIMINATION
}

\author{
Richard H. McAdams*
}

Tn Shakespeare's history of King Henry V, when the time comes for the young King to ready his troops to battle a much larger French force at Agincourt, he delivers a stirring speech that many regard as a masterpiece of inspirational rhetoric. Rejecting his advisor's lament for more men, he responds: "No, my fair cousin:/ If we are marked to die, we are enow/ To do our country loss: and if to live,/ The fewer men, the greater share of honour." 1 The King proclaims his personal desire for honor, offers safe passage back to England for those who do not wish to fight, and then describes how those who stay will be celebrated on future anniversaries of this day of battle, known as the Feast of St. Crispian:

And Crispin Crispian shall ne'er go by,

From this day to the ending of the world,

But we in it shall be remembered;

We few, we happy few, we band of brothers:

For he to-day that sheds his blood with me

Shall be my brother....

And gentlemen in England, now a-bed,

Shall think themselves accursed they were not here;

And hold their manhoods cheap, whiles any speaks

That fought with us upon Saint Crispin's day. ${ }^{2}$

For those of us who strive to be hard-headed theorists of human behavior, and who use economics and game theory to reveal the consequences of legal rules, our initial response to this speech is likely to be: "What a disaster." The King and his soldiers are about to risk their lives. Yet he denies wanting more men though additional troops would obviously better their odds of surviving and winning. Such a non sequitur can only raise doubts about the clarity of Henry's think-

* Assistant Professor of Law, Chicago-Kent College of Law, Illinois Institute of Technology. I would like to thank Linz Audain, Ian Ayres, Anita Bernstein, Robert Cooter, Jacob Corré, Kenneth Dau-Schmidt, John Donohue, Robert Ellickson, Alex Johnson, Pamela Karlan, Michael Klarman, Hal Krent, Saul Levmore, Anna-Maria Marshall, John Monahan, George Rutherglen, Stewart Schwab, Maxwell Stearns, Dan Steward, William Stuntz, and Peter Swire for their insightful comments on earlier drafts, as well as the participants in the Faculty Workshops at Indiana University School of Law and the University of Virginia School of Law. Scott Fisher, Julie Keywell, and Joe Studer provided exemplary research assistance. My work on this Article was supported by the Marshall D. Ewell Research Fund.

1 William Shakespeare, Henry V, act 4, sc. 3, ll. I9-22 (John D. Wilson ed., Cambridge Univ. Press 1968) (1623).

2 Id. 11. $57-67$. 
ing, which in turn can only increase the chances that his officers will question his commands. And, one might ask, what are the meaning and value of "honor" and "brotherhood"? If Henry wishes to motivate his men, a better strategy would be to spell out the potential material benefits (perhaps promising them more pay) or to remind them of the serious penalties for breaking their promise to fight. Offering to pay their way home, after the enhanced risk of loss has caused Henry's troops to regret their decision to join him in France, is sheer insanity. Finally, those "gentlemen in England now a-bed" will likely count themselves lucky for the opportunity to free-ride on a victory. After all, most of the benefits of victory - the general peace and prosperity of England - cannot be withheld from those who do not fight.

Economics, especially "law and economics," prides itself on the universal application of its method. ${ }^{3}$ Yet a theory of human motivation that did not grasp the meaning and power of this speech would be seriously flawed. Military leaders are among the more pragmatic and hard-headed people around and would likely scoff at this economic analysis of Henry's speech. Military rhetoric frequently appeals to honor and brotherhood. ${ }^{4}$ If such words prod men and women to risk their lives, one can only imagine how much greater is the power of such words relative to smaller material sacrifices. Consider, for example, the possible economic consequences of the following words:

Standing in the presence of this multitude, sobered with the responsibility of the message I deliver to the young men of the South, I declare that the truth above all others to be worn unsullied and sacred in your hearts, to be surrendered to no force, sold for no price, compromised in no necessity, but cherished and defended as the covenant of your prosperity, and the pledge of peace to your children, is that the white race must dominate forever in the South, because it is the white race, and superior to that race by which its supremacy is threatened. ${ }^{5}$

A principal purpose of this Article is to illuminate the economic power of this white supremacist oration by Henry Grady and of Henry V's

3 See, e.g., Gary S. Becker, The Economic Approach to Human Behavior 44 (1976); Richard A. POSNer, EConomic ANalysis of LAW 2 I (4th ed. 1992); Fred S. McChesney, Desperately Shunning Science, 7I B.U. L. REV. 28I, 28I (I99r).

4 See Morris Janowitz, The Professional Soldier 215, 220 ( 1960 ) ("In its contemporary form a major aspect of military honor comprises a sense of brotherhood and intense group loyalty."); S.L.A. MARSHALl, MEN AGAINST FIRE I49 (1947) ("[P]ersonal honor is the one thing valued more than life itself by the majority of men. The lips of the dying attest how strongly this force influences individual conduct in battle."); UNTTED STATES DEP'T OF THE ARMY, FM 22100, MitTARY LEadership 33, 39 (I96r). Echoing King Henry's St. Crispian speech, the military spends millions of dollars annually to entice volunteers for "the few, the proud, the Marines." See Paula Span, The Marines Go Medieval, WASH. PosT, Mar. 22, 1992, (Magazine) at 25 (noting that the Marine Corps' ad budget is almost \$ro million).

5 Henry W. Grady, The New South and Other Addresses 55 (1969). 
justly celebrated speech, as well as to examine the precise parallel between the two.

Each speech appeals to group interests, group loyalty, and group identity. The ubiquity of social groups says something of their importance: groups include not just firms, trade associations, and families, but groups based on demographic traits such as race, gender, or age, and those based on membership, such as fraternities or sororities, amateur sports teams, gangs, the Rotary or Elks Clubs, or private lunch clubs. Undoubtedly, some or all of these groups, like the firm, ${ }^{6}$ serve the individual's interest by minimizing the transaction costs she incurs while acting to satisfy her preference for whatever interest or function the group facilitates. But that explanation offers no insight into the meaning or power of the speeches of Henry $\mathrm{V}$ and Henry Grady.

This Article offers an economic theory to explain why individuals make material sacrifices for group welfare. My thesis is that a material view of human motivation underestimates both the level of cooperation that groups elicit from their members and the level of conflict that groups elicit from each other. A single group dynamic connects these added increments of cooperation and conflict: groups achieve solidarity and elicit loyalty beyond what economic analysis conventionally predicts, but solidarity and loyalty within groups lead predictably, if not inevitably, to competition and conflict between groups. The connection is the desire for esteem or status. Groups use intra-group status rewards as a non-material means of gaining material sacrifice from members, but the attendant desire for inter-group status causes inter-group conflict. This theory explains the power of King Henry's speech, which appeals to the individual's identification with the group ("we band of brothers") and effectively describes the status reward by contrasting other members of the group (those gentlemen left in England) who will not share in it. ${ }^{7}$ At the same time, the war itself was the product of England's desire for esteem and status - more specifically, Henry's desire for honor - which can only be achieved by conquering France.

This two-fold importance of status is essential to a genuine understanding of race discrimination, which has eluded economics. Discrimination is a means by which social groups produce status for their members, but pivotal to understanding this form of inter-group confict is the role that status plays in generating the intra-group cooperation necessary to make discrimination effective. Absent the desire for intra-group status, selfish individuals would not make the material

6 See Ronald H. Coase, The Firm, the Market, and the Law 33-55 (1988).

7 Cf. Thomas Wolfe, Chickamauga, in Chickamauga and Other Crvil War Stories 4I, 60 (Shelby Foote ed., 1993) ("TThe Civil War] would give us all a chance to wear a uniform ..., to shoot some Yankees and to run 'em north, and then to come back home and lord it over those who hadn't been and be a hero and court the gals."). 
sacrifices that discrimination requires. In this context, Henry Grady's racist speech is an economically explicable (if unusually candid) means of enlisting white troops in the ongoing status warfare, urging them to "compromise[] in no [material] necessity" the process of discriminating against, and thereby subordinating, the blacks whose inferior position produces a status gain for whites. The rhetoric helps establish a norm of white behavior, the abrogation of which will lower the ingroup status of non-conforming whites.

Race discrimination is the best and most important illustration of what I view as a more general phenomenon of intra-group cooperation and inter-group conflict. Before discussing race, however, I must articulate the general theory - to establish empirically that, because of concern for status, cooperation arises within groups and conflict occurs between groups. Part I sets forth puzzling instances of intra-group cooperation in experimental "dilemma" situations and elsewhere, which are not explained by existing economic theory but are well explained by concern for the esteem of other group members. Part I then proposes a model that describes how "esteem payments" afford groups a novel means of solving their collective action problems and, finally, how this same mechanism leads inevitably to inter-group status conflict. Part II considers the particular problem of race discrimination - the deficiencies in existing economic theory, the superior ability of a status-production model to explain many race-related phenomena, and the implications of such a model. In particular, if race discrimination is a means of producing group status - if groups are engaged in a form of status "warfare" - then discrimination presents the same case for government prohibition that exists for more traditional government restraints on force and fraud.

\section{Explaining "Excess" Cooperation and Conflict:} AN ECONOMIC THEORY OF SOCIAL GROUPS

Current economic theory fails to predict the prevalence of cooperation and conflict in human affairs. Considerable evidence supports David Hume's observation that "[w]hen men are once inlisted on opposite sides, they contract an affection to the persons with whom they are united, and an animosity against their antagonists: And these passions they often transmit to their posterity." Economics has been slow to address the function of social groups and the means by which they engender levels of loyalty and hostility in apparent defiance of conventional notions of material selfishness. But the psychic motivations that explain these "passions" - and the resulting intra-group cooperation and inter-group conflict - are reconcilable with rational self-interest.

9 David Hume, Essays 54, 58 (Eugene F. Miller ed., Liberty Classics 1985) (1758). 
This Part presents the modern evidence that supports Hume's claim. Initially, section A examines the empirical evidence that people cooperate beyond conventionally predicted levels. This "excess" cooperation is explained neither by sophisticated rational choice mechanisms such as reciprocity, nor by unselfish motives such as altruism. Instead, the experimental data indicate that cooperation is related to group membership. Section B advances a theory to account for this data: individuals who seek to maximize the esteem they receive from others have selfish reasons to contribute to group status. Two concepts of "group" are advanced: one defined externally by common characteristics observable by third-parties, and one defined internally by relationships among the members. In each case, there are selfish but nonpecuniary reasons for cooperating with one's group members. Finally, section $C$ suggests reasons that the very mechanisms that increase cooperation within groups also increase conflict between groups, and considers evidence that such status-based "excess" conflict exists.

\section{A. The Empirical Evidence of "Excess" Cooperation}

To understand conflict among social groups, we must first understand how groups elicit cooperation from their members. Game theorists study the strategic interactions of individuals, and their most compelling contribution is their description of the difficulties groups face in procuring the cooperation of members. In contrast to Adam Smith's "invisible hand," which guides society to desirable outcomes though individuals are selfishly motivated, ${ }^{10}$ game theory describes "collective action problems" - situations in which individually rational decisions lead to sub-optimal collective outcomes. ${ }^{11}$ The classic example is the prisoner's dilemma, ${ }^{12}$ but the basic problem exists in

10 See Adam Smith, 1 The Wealth of Nations $477-78$ (Edwin Cannan ed., Univ. of Chicago Press 1976) (ז776).

11 Jon Elster concisely describes the collective action problem:

Suppose that each member of a group has the choice between engaging in a certain activ-

ity and not engaging in it. The group has a collective action problem if it is better for all

if some do it than if nobody does, but better for each not to do it.

JoN Elster, Nuts aNd Bolts for the Social ScIENCES 126 (1989); see Russell HaRdin, Collective Action 8-9, I6-22 (I982); Mancur Olson, JR., The logic of Collective ACTION 5-22, 53-65 (I965).

12 In the example from which the dilemma draws its name, a prosecutor offers two prisoners the same bargain. If both prisoners remain silent, the prosecutor will use existing evidence to convict each of a minor crime for which each will serve one year in prison. If only one of the two prisoners confesses, the confessor will serve no time, but her testimony will be used to convict the non-confessor of a more serious crime for which she will serve five years. If both prisoners confess, each will serve an intermediate sentence of three years. Each prisoner must make an irrevocable decision without knowing how the other decides. Under these conditions, there is a "dominant" strategy, meaning a strategy that is best for an individual regardless of what decision the other individual makes. If prisoner $B$ confesses, prisoner $A$ is better off confessing and thereby serving three years instead of five. If $B$ remains silent, $A$ is still better off confessing and thereby serving zero years instead of three. Prisoner $B$ faces exactly the same set of considera- 
more complex situations with more than two parties: each individual faces a choice essentially between cooperation and defection, where the dominant strategy for each individual is defection, but where mutual defection is worse for everyone than mutual cooperation. The interest in studying such "games" is generated by the belief that they represent a fundamental feature of social life. ${ }^{13}$ Whether it is the undersupply of "public goods,"14 the overconsumption of common resources, 15 or related difficulties, the problem of collective action is commonly offered as a rationale for government regulation. ${ }^{16}$ Conversely, many private economic practices can best be understood as mechanisms for solving collective action problems. ${ }^{17}$

The focus of this section and the next is a particular mechanism for solving collective action problems commonly ignored by legal economists: groups achieve cooperation by allocating intra-group status. To persuade the skeptical that the desire for esteem exists and is necessary to explain important examples of cooperation, I could begin with a number of real-world examples of group cooperation. ${ }^{18}$ It is diffi-

tions. The dilemma occurs because $A$ and $B$, each acting to further her own interests, will each decide to confess, yet mutual confession yields an outcome (three years each) that is for each unambiguously inferior to mutual silence (one year each). Although each would prefer mutual silence to mutual confession, the individual nature of the decision making produces the latter.

13 See, e.g., Robert Axelrod, The Evolution of Cooperation 7 (1984); Elinor Os. TROM, Governing the CoMmons: The Evolution of Institutions for Collective Action 23-38 (I990); William Poundstone, Prisoner's Ditemma i-9 (1992).

14 Public goods are those goods that are non-exhaustible - because consumption by one does not preclude consumption by others - and non-excludable - because it is not feasible to prevent non-contributing individuals from enjoying the good once it is produced. See RoBERT CoOTER \& ThOMAS UlEN, LAW AND EcoNomcs 46 (1988). Since everyone benefits when one produces a public good, selfish individuals attempt to "free-ride" on the contributions of others, which leads the market to undersupply such goods. See id. at 46-48.

15 When a depletable resource is publicly owned, each individual gains the full benefit of her consumption but shares the cost with all other users. The result is inefficient depletion of the resource. See Ostrom, supra note 13, at I-3, 103-10; Garrett Hardin, The Tragedy of the Commons, I62 SCIENCE I243, I244 (Ig68).

16 The state can solve the commons problem, for example, by defining and enforcing private property rights. When one person bears all the costs of resource depletion, she will stop consuming when the marginal cost of consumption exceeds the marginal benefit. See OsTrom, supra note $\mathrm{I}_{3}$, at I2-I3. When private ownership is impractical, regulation may simply prohibit overconsumption. See id. at 8-II.

17 See, e.g., Charles J. Goetz \& Robert E. Scott, Principles of Relational Contracts, 67 VA. L. REv. I089, x103-05, Iro9-II (198x); Saul Levmore, Monitors and Freeriders in Commercial and Corporate Settings, 92 YALE L.J. 49, 76-85 (I982). Indeed, legal rules are sometimes justified by the need to maintain problems of collective action. Each firm in a cartel, for example, has the incentive to free-ride on price-fixing by underselling the cartel price, a strategy that prevents the cartel from existing at all. Antitrust policy is urgently concerned with the tools firms might use to overcome this collective action problem. See Ian Ayres, How Cartels Punish: A Structural Theory of Self-Enforcing Collusion, 87 CoLUM. L. REv. 295, 304-12 (Ig87). Indeed, the argument of Part II.C.2 is that antidiscrimination laws are needed to prevent collective action by whites.

18 For example, in the summer of 1993 , citizens of the communities flooded by the Mississippi River volunteered hours of hard physical labor, filling and stacking sand bags to save their towns. See Ralph Dummit, Neighbors Pitch In and Win, ST. Lours Post-Dispatch, Aug. 6, 1993, (St. 
cult, however, to distinguish subtle motivations in complex, uncontrolled events. Some might plausibly assert that, for any number of reasons, the individual's pecuniary self-interest in such examples happens to conform to the group interest. Others, including some critics of economic analysis, would argue that cooperation indicates the existence, not of a selfish interest in status, but of genuine altruism. ${ }^{19}$ Given these difficulties, I turn first to laboratory experiments, which can control for alternative motivations for cooperation.

I. Dilemma Experiments: Evidence of Non-Material Motivations for Cooperation. - Since the I950S, social scientists have conducted experiments with the prisoner's dilemma game, its multi-party variants, public goodds problems, and common resource problems. In each test, experimenters structure monetary payoffs to make defection or free-riding the dominant strategy. ${ }^{20}$ Despite the logical force of the monetarily dominant strategy, researchers have not found uniform defection. Many individuals defect, but a significant proportion - onequarter to two-thirds - chooses to cooperate. ${ }^{21}$ After more than two thousand social dilemma experiments, ${ }^{22}$ one of the "generally accepted" conclusions is that, when pecuniary incentives appear to compel defection, "many subjects do not defect."23 For those who employ game

Charles) at ISC. Flood control cannot be apportioned solely to those who contribute to it, and an individual's contribution is not likely to determine the success of the group effort. One would, therefore, have expected everyone to free-ride.

19 See amitai Etzioni, The Moral Dimension: Toward a New Economics 25-29 (I988); Robert H. Frank, Passions Within Reason: The Strategic Role of the Emotions 212-36 (I988); Howard Margolis, Selfishness, Altruism, and Rationality: A Theory of Social ChorCe II-I4 (I982); Amartya K. Sen, Rational Fools: A Critique of the Behavioral Foundations of Economic Theory, in BEXOND SELF-INTEREST 25, 34-36 (Jane J. Mansbridge ed., I990).

20 See N.L. Kerr, Motivational Choices in Task Groups: A Paradigm for Social Dilemma Research, in EXPERmental Social Dinemmas I-9 (Henk A.M. Wilke, Dave M. Messick \& Christel G. Rutte eds., 1986); David M. Messick \& Marilynn B. Brewer, Solving Social Dilemmas: A Review, 4 Rev. Personality \& Soc. Psychol. II, I7-29 (1983). Until the early I970s, "experimental gaming was devoted overwhelmingly to two-person games," but has since focused on "[t]he Multi-Person ... Prisoner's Dilemma . . . and the strategically equivalent Commons Dilemma." Andrew M. Colman, Game Theory and Experimental Games i68 (1982) (citations omitted).

21 See Etzioni, supre note $\mathrm{I9}$, at 60-6r; Linnda R. Caporael, Robyn M. Dawes, John M. Orbell \& Alphons J.C. van de Kragt, Selfishness Examined: Cooperation in the Absence of Egoistic Incentives, 12 BeHAV. \& BrAIN SCI. 683, 687-92 (1989); Robyn M. Dawes, Social Dilemmas, 3I ANN. REv. PSYCHOL. I69, I85-86 (I980).

22 See Robyn M. Dawes, Alphons J.C. van de Kragt \& John M. Orbell, Cooperation for the Benefit of Us - Not Me, or My Conscience, in BEYOND SELF-INTEREST, supra note 19, at 97, I00.

${ }^{23}$ John M. Orbell, Alphons J.C. van de Kragt \& Robyn M. Dawes, Explaining DiscussionInduced Cooperation, 54 J. Personality \& Soc. Psychol. 8II, 8II (r988). A recent study is illustrative. In a matrix with the highest "sucker's payoff" (the payoff for cooperating when the other party defects), there was a $\$ 7$ loss if one cooperated when the other defected, and a $\$ 5$ gain for defecting when the other cooperated; mutual cooperation paid $\$ 2$ each; mutual defection incurred a $\$ 5$ loss for each. See John M. Orbell \& Robyn M. Dawes, Social Welfare, Cooperators' Advantage, and the Option of Not Playing the Game, 58 AM. Soc. Rev. 787, 788, 791 (I993). The 
theory to predict the consequences of legal rules, this residuum of cooperation demands explanation. ${ }^{24}$

One immediate and material explanation is reciprocity. When future interactions are likely, reciprocity is possible, and defection may no longer be the dominant strategy. One reciprocal strategy is "tit-fortat," in which one begins by cooperating and then responds in future rounds by doing whatever the other player did in the previous round. ${ }^{25}$ Considerable evidence demonstrates the success of tit-for-tat in preventing mutual defection in iterated prisoner's dilemmas. ${ }^{26}$

Reciprocity does not, however, explain the cooperation observed in the dilemma experiments discussed above. Reciprocity requires future interaction in which players can reciprocate past decisions. Theorists still predict mutual defection for "one-shot" prisoner's dilemmas. ${ }^{27}$ Yet a large number of the empirical tests of collective action problems

cooperation rate was $51 \%$. In four other matrices, cooperation ranged from $35 \%$ to $54 \%$. See id. at 794. These games, however, are merely the control for the manipulations that were actually the heart of this experiment, namely, dilemma games in which the players could "opt out" of the game entirely. See id. Thus, cooperation in such experiments is sufficiently established that researchers have moved on to more interesting questions. See also John M. Orbell, Peregrine Schwartz-Shea \& Randy T. Simmons, Do Cooperators Exit More Readily Than Defectors?, 78 AM. POL. SCI. REv. 147, 147, 155-60 (1984) (proposing theories to explain why cooperators are less likely to exit than defectors).

24 One explanation is that the subjects do not understand the game, but there are several reasons to reject this possibility. First, researchers in these studies typically take great pains to ensure that the subjects understand the game. See Caporael, Dawes, Orbell \& van de Kragt, supra note $2 \mathrm{I}$, at 688 . Second, considerable evidence suggests that permitting subjects to talk with each other increases cooperation, even though discussion tends to increase the subjects' understanding of the strategic tension of the game. See infra notes 40-50 and accompanying text. In fact, some evidence suggests that, absent discussion, cooperators understand the strategic structure of the game better than defectors. See Harold H. Kelley \& Janusz Grzelak, Conflict Between Individual and Common Interest in an N-Person Relationship, $2 \mathrm{I}$ J. Personality \& Soc. Psychol. 190, 195-96 (1972).

25 See Anatol Rapoport \& Albert M. Chammah, Prisoner's Dilemma: A Study in CONFLICT AND COOPERATION 207-08 (I965).

26 See Colman, supra note 20 , at 124 ; see also AXELrod, supra note 13 , at $40-42$ (discussing computer program prisoner's dilemma tournaments won by tit-for-tat); id. at $73-87$ (discussing real-world examples, including reciprocal cooperation in minimizing artillery casualties among opposing forces in World War I trench warfare). By reciprocating cooperation, a player using tit-fortat offers other players the possibility of large, long-run gains from repeated cooperative interactions. By retaliating immediately and without exception to defection, the player also forecloses the possibility of long-run gains from defection. See id. at 53-54, r18-20.

27 See AXELROD, supra note 13, at ro. Even when the game is repeated, reciprocity works only if the players do not know when the game will end. See id. Otherwise, each player reasons that the last round of play represents a one-shot prisoner's dilemma in which the dominant strategy is to defect. For any round preceding a round in which the player expects mutual defection, the player has no reason to cooperate. This logic pushes back the decision to defect to the first round of play. See Jon Elster, The Cement of Society: A Study of Social Order 43 (1989) (expressing uncertainty about this reasoning but noting the "nearly unanimously held view that defection is the rational strategy" in finitely repeated games). But see HARDIN, supra note II, at I45-50 (denying that rationality requires defection regardless of how many times the game is finitely repeated). 
were intentionally designed as "one-shot" games to exclude the opportunity for reciprocity, and these tests have repeatedly found significant amounts of cooperation. ${ }^{28}$ In the very circumstance in which there is no material reason to cooperate, there is the undeniable fact of cooperation. Thus, however powerful reciprocity may be in some contexts, a significant residual level of cooperation remains unexplained. ${ }^{29}$

One might note, finally, that the material stakes in these experiments typically involve only a few dollars or less. Though higher stakes might cause people to free-ride, the question is what explains subjects' consistent failure to free-ride when low material stakes suggest they should. After all, entire industries arise to capture stakes of a similar size; what seems low in isolation is vast when aggregated over a large population. Whether we can say the same of the motivations causing this residual cooperation requires us first to discover what those motivations are.

2. Dilemma Experiments: Evidence of Non-Altruistic Motivations for Cooperation. - Critics and reformers of economic modeling have pointed to the dilemma experiments described above as proof of altruism or a commitment to principles of fairness. ${ }^{30}$ Yet a full review of the psychological research on collective dilemmas refutes this thesis. Some sense of "group identity," rather than altruism or fairness, explains the variations in cooperation researchers have observed. ${ }^{31}$ of particular note are studies revealing that individuals cooperate more

28 See, e.g., Robert H. Frank, Thomas Gilovich \& Dennis T. Regan, Does Studying Economics Inhibit Cooperation?, I3, I4 fig.6 (I992) (unpublished manuscript, on file with the Harvard Law School Library) (finding that $39.6 \%$ of economics majors and 6 т.2\% of non-economics majors cooperated in a prisoner's dilemma); Gerald Marwell \& Ruth E. Ames, Experiments on the Provision of Public Goods. I. Resources, Interest, Group Size, and the Free-Rider Problem, 84 AM. J. Soc. 1335, I349-50 (1979) (finding that the typical subject invested $57 \%$ of her available resources in a public good, two-thirds of subjects invested more than half, and $22 \%$ invested all); Orbell, van de Kragt \& Dawes, supra note 23, at 813, 816-17 (finding that with discussion, 79\% of subjects cooperated, while with no discussion and other factors, $20 \%$ cooperated); Orbell, Schwartz-Shea \& Simmons, supra note 23, at I53 (finding that allowing exit and discussion led over $75 \%$ to cooperate and that allowing exit and no discussion led $18 \%$ of those who chose to stay to cooperate).

29 One might argue that, even in "one-shot" dilemma experiments, subjects fear being "punished" outside the experiment should they ever encounter the other players. Yet subject $B$ will not seek to punish subject $A$ unless doing so would create some benefit for $B$. One might argue that $B$ will be less likely to cooperate with $A$ in any future dilemma setting. However, when they meet in a future real-world dilemma, $A$ and $B$ will have no reason to cooperate unless they expect to interact with sufficient frequency to permit reciprocity. But given sufficient reciprocity, there is no reason for $B$ to mistrust $A$. One may be tempted to say that $A$ has shown herself to be a "defector" by nature, but $A$ merely defected in the laboratory when it was rational to do so. A new game is now afoot in which the tit-for-tat strategy is a good bet for both $A$ and $B$. Subjects should therefore not fear defecting in the one-shot experiment. That so many do not defect remains a puzzle.

30 See sources cited supra note I9.

31 I am not claiming that altruism and a concern for fairness do not exist, but only that neither fully explains the residual cooperation in these experiments. 
frequently in dilemma games than do groups of individuals and studies revealing that discussion increases the level of cooperation in dilemma games.

First, many prisoner's dilemma studies have contrasted games between individual subjects with games between groups of subjects. Holding the payoffs constant, these studies consistently find significantly more cooperation when individuals play individuals than when teams play teams. ${ }^{32}$ One study, for example, found that three-person groups defected an average of 8.73 times in twenty rounds, compared to an average of 1.8 defections out of twenty when individuals played each other. ${ }^{33}$ This individual-group "discontinuity" is consistent with research finding that the formation of a purely experimental "group" can elicit a bias in favor of in-group members, against out-group members, or both. Psychologists discovered this when they set out to create a base line in which individuals would have no reason to favor their own group. ${ }^{34}$ To their surprise, whenever subjects were divided into groups, people consistently evaluated members of their own group more favorably than members of other groups. ${ }^{35}$ Summarizing this ef-

32 See, e.g., Chester A. Insko et al., Interindividual-Intergroup Discontinuity in the Prisoner's Dilemma Game, 38 J. CoNfLICT Resol. 87 (1994); S.S. Komorita \& C. William Lapworth, Cooperative Choice Among Individuals Versus Groups in an N-Person Dilemma Situation, 42 J. PERSONALrTy \& Soc. Psychol. 487, 494 (1982); Debra M. McCallum et al., Competition and Cooperation Between Groups and Between Individuals, 21 J. EXPERIMENTAL Soc. PsYcHol. 301, $3^{1} 4$ (1985). Because cooperation fluctuates while the formal payoffs remain the same, these data also demonstrate that pecuniary self-interest does not motivate the residual cooperation.

33 See John Schopler, Chester A. Insko, Kenneth A. Graetz, Stephen M. Drigotas \& Valerie A. Smith, The Generality of the Individual-Group Discontinuity Effect: Variations in Positivity-Negativity of Outcomes, Players' Relative Power, and Magnitude of Outcomes, 17 PersonaltTy \& Soc. PsYchol. BuLL. 612, 616 (I99I). Individual players therefore earned more money than team players. See id. Researchers view individual-group discontinuity as evidence of "ethnocentric schemata for own and other group": individuals learn that inter-group relations are competitive, while intra-group relations are cooperative. Id. at 6r3; see also Warner Wilson \& Myra Kayatani, Intergroup Attitudes and Strategies in Games Between Opponents of the Same or of a Different Race, 9 J. Personality \& Soc. Psychol. 24, 27 (I968) (explaining that pairs cooperated with each other $84 \%$ of the time but cooperated with another pair only $43 \%$ of the time).

34 By establishing a base line group, researchers could have attempted to measure the causes of group bias in a controlled setting. See Henri Tajfel, Differentiation Between Social GroupS Io (1978). In the original experimental design, experimenters "randomly classified [subjects] as members of two nonoverlapping groups - ostensibly on the basis of some trivial performance criterion." Henri Tajfel \& John C. Turner, The Social Identity Theory of Intergroup Behavior, in Psychology of Intergroup Relations 7, 13 (Stephen Worchel \& William G. Austin eds., 1986). The "trivial performance criterion" was initially whether they tended to overestimate or underestimate the number of dots on a page (when there was insufficient time for counting) and was later some non-performance criterion (for instance, whether people preferred Klée or Kandinsky). Subjects then made evaluative decisions about other subjects, anonomously "awarding amounts of money to pairs of other subjects (excluding self) in specially designed booklets". Id. at 13-14.

35 The results were replicated "even when the assignment to groups was made explicitly random." Tajfel \& Turner, supra note 34, at I4; see also Louise Lemyre \& Philip M. Smith, Intergroup Discrimination and Self-Esteem in the Minimal Group Paradigm, $49 \mathrm{~J}$. PERsonality \& Soc. Psychol. 660, 660 (1985) (stating that "[m]ore than 20 experiments" suggest this finding). 
fect, one pair of researchers stated that "mere awareness of the presence of an out-group is sufficient to provoke intergroup competitive or discriminatory responses on the part of the in-group."36

Additional confirmation of the importance of groups is provided by dilemma experiments in which researchers elicited differences in cooperation by symbolically invoking "real-world" group memberships. In one study, psychologists observed significantly more cooperation from subjects sharing a common resource when they told the subjects that they were being evaluated as a single group against groups not then a part of the experiment (for example, college students versus non-students) than when they told the subjects that they were being evaluated as members of one of two subgroups in the experiment (for example, psychology majors versus economics majors). ${ }^{37}$

These studies appear to confirm David Hume's insight that individuals "have such a propensity to divide into personal factions, that the smallest appearance of real difference will produce them."38 The experimenter's arbitrary division of subjects into groups is sufficient to "factionalize" them, causing more competitive behavior between groups

36 Tajfel \& Turner, supra note 34, at 13. Subjects not only favored in-group members but followed a strategy of maximizing the relative difference between the groups, even when that strategy prevented them from maximizing absolute gain for their own group. See TAJFEL, supra note 34 , at 80; Lemyre \& Smith, supra note 35 , at 660 .

37 See, e.g., Roderick M. Kramer \& Marilynn B. Brewer, Effects of Group Identity on Resource Use in a Simulated Commons Dilemma, 46 J. PERsonaltry \& Soc. Psychol. I044, ro55-56 (r984). The common resource was represented by a sum of 300 points, from which each individual could "harvest" zero to ten points on each of twelve or twenty-four rounds. See id. at 1047. Because the pool would grow by a certain amount each round, the pool would be selfsustaining if the individuals restrained their consumption to an average of five points per round. But the points could be cashed in at the end of the experiment (typically for five cents each), which created an incentive to take as much as possible for oneself. See id. at 1047-48, 105 I, r053. In each experiment, three subjects were told that three other subjects (who did not actually exist) would send their choices from another linked computer facility. See id. at 1046. In one experiment, the subjects were also told that the other subjects were elderly residents of the community and either that the researchers were studying how residents of the local community behaved in comparison to residents of other communities, or that the researchers were studying "'how the behavior of young people compares to the behavior of elderly persons." Id. at I048. In another experiment, the monetary value of the points was not fixed but was determined by either a single lottery for all six subjects or two lotteries, one for each three-person subgroup. See id. at ro53. These simple manipulations produced statistically significant differences in behavior. See id. at 1049, 1051, I054. The study reports:

[I]n no case did the mean take per trial block of individuals in differentiated subordinategroup-identity conditions reach the optimal level required to sustain the resource pool. When a superordinate group boundary was salient, however, mean individual takes reached or fell below this optimal level in all three experiments under depletion conditions.

Id. at Io55.

Other studies reach similar results. See Marilynn B. Brewer \& Roderick M. Kramer, Choice Behavior in Social Dilemmas: Effects of Social Identity, Group Size, and Decision Framing, $50 \mathrm{~J}$. Personality \& Soc. Psychol. 543, 548-49 (I986); Kenneth L. Dion, Cohesiveness as a Determinant of Ingroup-Outgroup Bias, $28 \mathrm{~J}$. PERSONALITY \& SOC. PSYCHOL. I63, I66-7I (I973).

38 Hume, supra note 9, at 56-57. Factionalization implies cooperation within factions as well as conflict between them. 
than between individuals and favoritism for members of one's own "group." Neither a general concern for the welfare of others nor a concern for fairness explains why subjects were so much less cooperative with other subjects whom the experimenter placed in a different group. 39

The second body of studies that challenge the altruism-fairness explanation are those involving discussion. Repeated study shows that permitting communication between the subjects in a prisoner's dilemma situation dramatically increases the level of cooperation; 40 indeed, discussion as much as doubles cooperation rates. ${ }^{41}$ Yet "in none of these experiments does group discussion change the fact of defection's dominance"; 42 given the structure of the experiments, there is no reason for any threat or promise to be credible. ${ }^{43}$

To explain this puzzle, researchers varied the conditions of discussion in multi-party prisoner's dilemmas. In one study, the experimenters randomly divided subjects into two groups and placed each group in a separate room. ${ }^{44}$ The experimenters permitted ten minutes of discussion in half the groups and no discussion in the others. In addition, half the groups were told that their decisions would affect the payoff for their own group, while the other half were told that their decisions would determine the payoff for the other group and, conversely, that the decisions of the other group would determine the payoff for their group. ${ }^{45}$ The results were striking. When subjects believed their deci-

39 One might explain the data as the product of "group altruism." This term, however, obscures the fact that the individuals not only feel more "altruistic" toward members of their groups than toward non-members, but also seem willing to sacrifice the welfare of non-members for the sake of their group. See supra notes $35-37$ and accompanying text. And there is no reason to think that it is less "fair" for teams than for individuals to cooperate in a prisoner's dilemma.

40 See Gary Bornstein, Amnon Rapoport, Lucia Kerpel \& Tani Katz, Within- and BetweenGroup Communication in Intergroup Competition for Public Goods, 25 J. ExPERIMENTAL Soc. Psychol. 422, 424 (1989); Orbell, Schwartz-Shea \& Simmons, supra note 23, at 154-55 (reporting that, when subjects had the third option of exit, discussion not only increased cooperation but decreased exit); Orbell, van de Kragt \& Dawes, supra note 23, at 8Ir.

41 See, e.g., FRANK, supra note I9, at 142 (reporting that $37 \%$ of subjects cooperated when permitted only ro minutes of discussion and forbidden to make promises to cooperate, $61 \%$ cooperated when permitted 30 minutes of discussion but forbidden to promise, and $68 \%$ cooperated when permitted 30 minutes of discussion without restrictions); Robyn M. Dawes, Jeanne McTavish \& Harriet Shaklee, Behavior, Communication, and Assumptions About Other People's Behavior in a Commons Dilemma Situation, 35 J. Personality \& Soc. Psychol. 1, 5 (1977) (finding that defection rates in a prisoner's dilemma game declined from $73 \%$ with no communication to $65 \%$ with communication not regarding the game, to $26 \%$ with communication regarding the game but no promises, and to $16 \%$ with communication that included promises).

42 Orbell, van de Kragt \& Dawes, supra note 23 , at 8 ir.

43 Communication should, in theory, be relevant only if it permits someone to make a credible threat or promise. There is every reason for people to try to fool others into believing their promises to cooperate or retaliate, but in a one-shot game between strangers, there is no selfinterested reason for people to follow through on those promises or threats.

44 See Dawes, van de Kragt \& Orbell, supra note 22, at 103-0\%.

45 See id. at 103-04. 
sions would affect the payoffs of members of their own group, discussion increased cooperation from thirty-four percent to sixty-nine percent. But when subjects believed that their decisions affected payoffs for the other group, discussion slightly reduced cooperation. ${ }^{46}$ The researchers concluded that "discussion does not enhance contribution when beneficiaries are strangers." 47 Of course, all of these subjects were "strangers" to each other in the sense that they had never met before the experiment and were randomly assigned to the different groups. Yet with ten minutes of discussion about their upcoming decisions, they were, in an important economic sense, no longer strangers. Limited discussion was sufficient to dramatically increase cooperation if and only if the discussants were the beneficiaries of the cooperation.

These findings further demonstrate that altruism and fairness do not fully explain excess cooperation in the prisoner's dilemma. If discussion invoked a general concern for others or for fairness, it should not matter that the beneficiaries are arbitrarily placed in another room. Instead, discussion seems to permit formation of a group identity that creates a special reason for discussants to cooperate. ${ }^{48}$ In the transcripts of the subjects' pre-decision discussion, people frequently referred to what "we" - the members of the group - should do. Moreover, where one group knew that its decisions would affect only the other group, there were "frequent statements that the best results would occur if we all keep and they all give to us." 49 The motive seems to fall far short of altruism or fairness. ${ }^{50}$ The kind of speech that so effectively increases cooperation tends to be an appeal not to principle, but to solidarity. Thus, successful inspirational rhetoric like Henry Grady's racist speech - is often centered around repeated invocations of an "us against them" image.

3. Cooperation Outside the Laboratory: Further Evidence That Groups Matter. - Although laboratory experiments more easily con-

46 See id. at Io6 (from $33 \%$ to $3 \mathrm{r} \%$ ).

47 Id.

48 Dawes and his colleagues have suggested promise-making as an alternative explanation for the effect of discussion (subjects can promise only if discussion is permitted). See Orbell, van de Kragt \& Dawes, supra note 23 , at 818 . But more recently they found greater support in the transcripts of the discussions for the group identity explanation. See Dawes, van de Kragt \& Orbell, supra note 22, at rog. Indeed, other studies on the effects of discussion on cooperation have found that most of the increase in cooperation can be obtained even if promising is not allowed. See sources cited supra note 4I; see also Orbell, Schwartz-Shea \& Simmons, supra note 23, at 158-59 (summarizing the group-identity explanations subjects gave for their decision not to exit a dilemma game).

49 Dawes, van de Kragt \& Orbell, supra note 22, at rog.

50 Based on to years of research, including " 27 different no-discussion conditions with 1,188 subjects in 178 groups, and for 12 different discussion conditions with 637 subjects in 95 groups," Dawes and his colleagues conclude that "with no discussion, egoistic motives explain cooperation; with discussion, group identity - alone or in interaction with verbal promises - explains its dramatic increase." Id. 
trol for alternative explanations, it is also appropriate to consider two real-world collective action problems: social protest and war. Although law and economics scholars have criticized Title VII, ${ }^{11}$ none has attempted to explain why individual blacks participated in the civil rights protests that led to its enactment. Social protests - such as marches, boycotts, and "sit-ins" - are costly to the individual. Although a group may benefit from collective protest, the gains will likely be enjoyed by all members of the group, regardless of whether they participated in the protest. Thus, social movements are rife with collective action problems, which usually prevents such movements from forming or succeeding. Posing this problem, Dennis Chong inquires how the civil rights movement of the I950s and I960s succeeded in mobilizing considerable collective action. ${ }^{52}$ Given the violence of white resisters, Chong rejects the possibility that material rewards explain the participation, ${ }^{53}$ recounting instead the importance of social incentives ${ }^{54}$ within small, pre-existing groups such as black churches. ${ }^{55}$

Consider also the high-stakes collective action problems in war. If all soldiers attempt to free-ride on the combat efforts of others, the result is a rout. S.L.A. Marshall argues forcefully that, for the bulk of soldiers, the only thing that stops them from fleeing in the face of fire is the opinion of those with whom the soldiers have formed social ties. ${ }^{56}$ Marshall's evaluation is based on the fighting effectiveness of "battle stragglers," soldiers separated from their fighting unit who tem-

51 See sources cited infra note 120.

52 See Dennis Chong, Collective Action and the Civil Rughts Movement 1-ra (199I). After reading Chong's explanation of how the movement solved its collective action problems, I came to believe that the prevailing economic criticisms of Title VII are based on assumptions that would make an explanation of the civil rights movement impossible; if selfish whites cannot coordinate discrimination in the face of market competition, neither should blacks have been able to cooperate to succeed in a civil rights movement.

53 See id. at $32-33$.

54 See id. at 34-35 ("The desires to gain or sustain friendships, to maintain one's social standing, and to avoid ridicule and ostracism are all social goals that constitute selective incentives for individuals to participate in collective action."). Chong explains how this non-material concern for reputation served as a motivator in civil rights activities like the freedom rides, the Montgomery bus boycott, the Selma voting drive, and the Greensboro lunch counter sit-in. See id. at 55-65. "We refuse one-time gains through free riding in order to retain the esteem, respect, and continued goodwill of those we care about." Id. at 55 .

55 See id. at $35-36$. Although social pressure is most effective in small, tightly knit groups, "[l]arge groups nevertheless can take advantage of the selective incentives provided by social pressures if they in turn comprise a network of much smaller organizational units." Id. at 35.

56 Marshall claims:

During combat the soldier may become so gripped by fear that most of his thought is directed toward escape. But if he is serving among men whom he has known for a long period or whose judgment of him counts for any reason, he still will strive to hide his terror from them. ... The majority are unwilling to take extraordinary risks and do not aspire to a hero's role, but they are equally unwilling that they should be considered the least worthy among those present.

MARShall, supra note 4, at I48-49; see JANOwITZ, supra note 4, at 220. 
porarily join an unfamiliar company. He found that individual stragglers had almost no "combat value" in a new unit, while small squads of stragglers "tended to fight as vigorously as any element:"57

Within the group increments the men were still fighting alongside old friends, and though they were now joined to a new parent body, they were under the same compulsion to keep face and share in the common defense. The individual stragglers were simply responding to the first law of nature which began to apply irresistibly the moment they were separated from the company of men whom they knew and who knew them. ${ }^{58}$

Even in the face of death - high stakes indeed - individuals cooperate not merely to secure material rewards, but also to preserve the opinion that group members hold of them. This, of course, is the very dynamic King Henry manipulates in his St. Crispian speech.

\section{B. Economic Explanations of "Excess" Cooperation:} The Production of Inter-Group and Intra-Group Status

If neither material self-interest nor altruism explains the residuum of cooperation, what can? And why does the level of cooperation vary so significantly with the manner in which individuals are categorized by group? This section proposes an answer: group-based status production. In the experiments discussed above, individuals behave selfishly, not altruistically, but their selfish end is the production of the non-material good of esteem. If individuals seek such non-material ends, members of social groups have another means of solving collective action problems - by allocating esteem to induce members to make contributions to group welfare. Once we add esteem consequences to the material payoffs of individual decisions in such settings, we can explain both the fact and the nature of residual cooperation.

This section argues that human beings seek esteem from others; in aggregate terms, they seek social status. Individuals derive status from groups in two ways: first, individuals gain esteem from strangers based on visible group memberships; and second, within a socially connected group, individuals are especially concerned with the esteem of fellow members. In each case, though for different reasons, status production creates a non-material incentive for group cooperation.

I. The Individual Preference for Esteem and Status. - If one assumes that individuals behave rationally, the only explanation for the subjects' behavior in the experiments discussed in Part I.A is that the subjects receive benefits from cooperation, or avoid costs from defection, that are not part of the formal, pecuniary payoff structure of 
the game. One simple way of explaining the cooperation is that the benefit they receive is the esteem of their fellow game-players.

In an earlier article, I described the pervasiveness and power of what I called "negative relative preferences - preferences for approaching or surpassing the consumption level of others."59 In particular, I offered evidence that people care greatly about achieving a relative social rank or social status. ${ }^{60}$ What one gains by attaining "status," however, is merely a state of mind - the opinion of others in society - that one is particularly worthy in some way. To understand "excess" cooperation, we should start with precisely this point: that one of the "basic pleasures"61 people seek in life is the esteem of others. ${ }^{62}$

That people care what others think of them is a parsimonious explanation of many phenomena. The desire for esteem explains, for example, why people are obsessed with the impression their goods make on others. ${ }^{63}$ The desire for esteem also underlies the common emotion of embarrassment: individuals feel a momentary but acute pain from loss of esteem at having others observe their missteps or indiscretions. ${ }^{64}$ And this desire for esteem helps explain the well-established finding that individuals conform dramatically in the face of a group judgment. Even when there is no material cost to disagreement, individuals appear to fear that dissent will adversely affect how others view them. ${ }^{65}$

Given this behavior, it is not implausible to say that some individuals would cooperate in what is nominally a prisoner's dilemma solely

59 Richard H. McAdams, Relative Preferences, IO2 YALE L.J. I, 9 (1992) (emphasis omitted).

60 See id. at 38-48.

61 BECKER, supra note 3 , at 145 (arguing that economics should strive to explain behavior with only a few preferences that reflect basic pleasures).

62 It would be trivial to say that people care about what others think of them as a means to furthering various material ends; the evaluations others make obviously affect the resources one can gain in trade. My claim, however, is that people also care quite a bit about what others think of them as an end in itself.

Esteem is objectively manifested in the ways people show each other respect: for example, who is permitted to speak first or without interruption; who is asked for advice and counsel; who sets the standard of fashion or humor. These objective prerogatives are valued, in my model, only as manifestations of the esteem individuals seek and are not separate ends in themselves.

63 See McAdams, supra note 59, at 38-44. The desire for esteem also explains why people care how their salary compares to that of their co-workers and why people save according to the size of their income relative to others. See id. at 45-46.

64 Consider, for example, being the only member of an audience to begin applauding at an inopportune moment. Embarrassment does not depend on the prospect of pecuniary consequences from one's blunder. We feel discomfort because - caring generally for esteem - we suffer when others think ill of us, even if they are strangers. Of course, people may internalize norms and feel embarrassment (or guilt) even when others are not present. But my point is that there is often an increase in the intensity of feeling if others know of our offending conduct.

65 See Bibb Latane, The Psychology of Social Impact, in Contemporary Readings in SoCial Psychology 288, 29I (David A. Scroeder, David E. Johnson \& Thomas D. Jensen eds., 1985) ("Eighty years of experimental evidence strongly shows that individuals are influenced by the actions and expectations of others."). 
to preserve the minimal esteem strangers (in that community) normally feel for one another. Individuals add the "esteem rewards" and "esteem penalties" to the material payoffs and choose accordingly. Esteem concerns may change the total payoffs enough to make cooperation rational. ${ }^{66}$

2. Members of "Shared-Trait" Groups Cooperate to Produce Inter-Group Status. - To explain the dilemma experiments adequately, an esteem theory must also explain why the level of cooperation varies with "group identity" measures. The concept of "shared-trait groups" explains the existence and variation in the level of cooperation observed in the experiments. By "shared-trait" group, I mean a collection of individuals who have in common some readily observable feature. In American society, people can roughly agree on how to group individuals - for example, by age, by language, or by physical characteristics we refer to as "race." In each case, on the basis of casual observation, one can determine reasonably well whether individuals fall within the category.

Observable traits are important because, when individuals encounter a stranger, they have no other basis for making an esteem judgment. If individuals feel particularly high or low esteem for others with the same trait, they tend to extend that judgment to the stranger. I am not describing irrational prejudice, but a simple application of the economics of information. Given the scarcity of information, it is rational to use cheaper information - proxies - to infer the existence of more expensive, individualized information. ${ }^{67}$ The economics literature describes the use of proxies for making decisions of material consequence (such as employment), but proxies can also be used for the allocation of status. Shared-trait group membership is a proxy people use for granting or withholding esteem to individuals they do not know personally.

The use of observable traits as proxies gives individuals a reason to care about the esteem-generating behavior of those with whom they share an observable trait. If an individual shares a trait with others, she expects strangers to extend her the esteem they have for the group that shares the trait. If these third-party observers know only an individual's putative group membership, the individual expects them to

66 Esteem concerns primarily reduce the benefits of defecting when the other party cooperates, possibly to the extent that a player is better off cooperating when the other party cooperates. Even with esteem, a player is still better off defecting when the other party defects, but defection is no longer the "dominant" strategy. Moreover, because mutual cooperation is better for both parties than mutual defection, communication may increase cooperation by assuring each that the other will cooperate.

67 The statistical theory of discrimination, for example, posits that people use race as a proxy to evaluate others by assuming in the absence of more specific information that the person has the average qualities of her race. The individual will benefit from the use of proxies if the savings in information costs outweigh the costs of inaccuracy. See infra note II6. 
judge her entirely on the basis of that membership. She therefore has a selfish concern that the group be highly esteemed in comparison to other groups. Even though the "members" of a group may not know or feel any affinity for each other, third-party categorization gives these members a reason to care about the group's status.

This proxy effect provides a parsimonious explanation of the variation in cooperation observed in the experiments reviewed above: in the laboratory, the experimenter is the third party who categorizes individuals. Any set of subjects the experimenter designates as constituting a group has a "shared trait" for purposes of the experiment. The subjects know that the researcher is observing and evaluating them as members of the group she created.68 In collective action experiments, the only means of distinguishing successful from unsuccessful groups is the extent to which the group cooperates and achieves the best collective result. Subjects in such experiments may earn additional benefits for cooperating or face additional costs for defecting - thus, esteem consequences may make cooperation a rational strategy.

Further, in the prisoner's dilemma studies, individuals playing the game against individuals cooperated at higher levels than teams playing the same game against teams. ${ }^{69}$ With team-play, individuals expect that the esteem they receive depends on the success of the arbitrarily created groups to which they belong. The proxy effect works to raise the payoff of defecting when the other team cooperates (the one way of "beating" the other team) and to lower the payoff of cooperating when the other team defects (thereby "losing"). With individual play, however, either there is no cognizable "group," or the group contains both of the subjects in the game. Thus any proxy effect works toward cooperation. If subjects understand that the experimenter will have other pairs play the game, they may imagine themselves being evaluated as a pair against other pairs, which raises the payoff of mutual cooperation (the best "pair" outcome) and lowers the payoff of mutual defection (the worst "pair" outcome). ${ }^{70}$

68 Once the group boundary arises, subjects within one group may also anticipate evaluating, and being evaluated by, subjects in the other group.

69 See supra notes $32-33$ and accompanying text.

70 Similarly, in the commons depletion experiments, subjects cooperated more if they believed the experimenter was evaluating all of them as a single group rather than as part of one of two subgroups. See supra note 37 and accompanying text. In the former case, the subjects apparently viewed depleting the pool as a form of group failure, the cost of which is a lower evaluation of the group and all its members. In the latter case, gaining the esteem of being on a successful team arguably required depleting the pool at a higher rate so that one's team of subjects would reap more than the other team. The "minimal inter-group paradigm" studies do not present a dilemma, but note that subjects rated others so as to maximize the difference in outcome between the groups rather than to maximize the absolute outcome for their own group. See supra notes 34-36 and accompanying text. The individuals behaved as if they sought to gain individual esteem by maximizing the proxy value of membership in their group. 
To the experiments previously reviewed, we may now add studies on relative deprivation as a cause of social protest. Relative deprivation refers to the fact that individuals react strongly to deprivation when others have what they lack. ${ }^{71}$ "Psychologists hypothesize that a central component of people's angry feelings over deprivation is a comparison between themselves and others who have the desired thing."72 Numerous studies have demonstrated the importance of comparison with others to feelings of relative deprivation and to behavior motivated by such feelings. ${ }^{73}$ Most important, many of these studies find that attitudes about inter-group comparisons predict participation in social protest, whereas attitudes about interpersonal comparisons do not. People are more likely to protest when they feel that the group to which they belong is relatively deprived than when they simply feel that they as individuals are relatively deprived..$^{74}$

In sum, laboratory experiments show that, even when the group is an entirely arbitrary construct, individuals seek to acquire esteem from "non-group" members by raising the status of what, in the eyes of those non-group members, is the individuals' group. Outside the laboratory, concern with how one's shared-trait group is regarded also motivates significant action.

3. Members of "Socially Connected" Groups Cooperate to Produce Intra-Group Status. - A second, more conventional understanding of the group posits that the members are, in some manner, socially connected. These socially connected groups are comprised of people who know each other, the paradigm cases being families, networks of friends, or social clubs. Such groups have two noteworthy features,

71 See Robert Folger, Reformulating the Preconditions of Resentment: A Referent Cognitions Model, in Soclal Comparison, Social Justice, and Relative Deprivation i83, I84-2iz (John C. Masters \& William P. Smith eds., I987); James M. Olson \& J. Douglas Hazlewood, Relative Deprivation and Social Comparison: An Integrative Comparison, in 4 ReLATIVE DePRTvation and Social Comparison I, 2-5 James W. Olson, C. Peter Herman \& Mark P. Zanna eds., I986).

72 McAdams, supra note 59, at 34; see also Faye Crosby, $A$ Model of Egoistical Relative Deprivation, 83 PsYCHOL. REV. 85 , 90 (1976) (maintaining that the first precondition of relative deprivation is that "[t]he person who lacks $X$ must . . . see that someone else . . possesses $X$ ").

73 See Thomas D. Cook, Faye Crosby \& Karen M. Hennigan, The Construct Validity of Relative Deprivation, in Social Comparison Processes 307, 320-23 tbl. 4 Jerry M. Suls \& Richard L. Miller eds., 1977) (collecting studies).

74 See Lise Dube \& Serge Guimond, Relative Deprivation and Social Protest: The Personal Group Issue, in 4 Relative Deprivation and Social Comparison, supra note 71, at 201, 204-Io. One researcher summarizes:

[F]raternalistic [relative deprivation] is useful for predicting white racism and support of black political candidates in the United States, militancy among black Americans and their approval of violence to gain their rights, attitudes of Québec nationalism among Francophone Canadians in Montreal, subjective satisfactions among members of Toronto's Chinese community, and outgroup attitudes among Chinese in Toronto and Muslims in India, respectively.

Kenneth L. Dion, Responses to Perceived Discrimination and Relative Deprivation, in 4 ReLAtive Deprivation and Soclal Comparison, supra note 71 , at 159, 174. 
each of which contributes to the group's ability to overcome collective action problems: individuals tend to care especially about the esteem of their fellow group members, and individuals tend to grant esteem to members who contribute to group welfare.

The first feature of socially connected groups is that individuals tend to value the esteem of fellow group members more than they value the esteem of non-members. If we care what others think of us, we care more intensely the more well-informed an opinion is; those with whom we have frequent interaction - group members - know us best. Moreover, the dilemma experiments in which the simple act of discussion generated greater cooperation among discussants indicate that even minimal social connection can significantly increase the concern for the esteem of another. In addition, the very reason many social groups exist is that the members share some skill, trait, or interest; members tend to value the esteem of in-group members more than outsiders because members share a sense of what skills or traits are worth possessing. ${ }^{75}$ Finally, there is a self-reinforcing aspect to the concern for intra-group status: we tend to value most the opinion of those we esteem highly, and we prefer to belong to social groups including such people. ${ }^{76}$

Given the especially high concern for esteem from socially connected group members, we can better understand high-stakes cooperation in the collective action problems presented by social protest and war. ${ }^{77}$ Military and social protest groups elicit cooperation by rewarding members with esteem or prestige based on how much they contribute to the group's welfare. Yet even if people seek intra-group esteem, the question remains why individual group members provide intra-group esteem to those who contribute to group welfare. The second noteworthy feature of socially connected groups is that members readily provide esteem to those who benefit the group; even without a central authority, members tend not to free-ride completely on the "esteem payments" of other members.

People provide esteem to members who benefit the group because, up to a point, thinking well of others is not a cost. To the contrary,

75 Although there are exceptions, individuals tend to value more highly the positive traits that they believe they possess. See, e.g., George R. Goethals, David M. Messick \& Scott T. Allison, The Uniqueness Bias: Studies of Constructive Social Comparison, in Social Comparuson 149, 149-50 (Jerry Suls \& Thomas A. Wills eds., I99I); Pawel Lewicki, Self-Image Bias in Person Perception, 45 J. Personality \& Soc. Psychol. 384, 385-87 (I983).

76 Even if an individual admires only a few leaders or "heroes" in the group, she will care about the opinion of other group members, who (especially if they know her better than the heroes do) can dramatically influence the leaders' esteem for her. Thus, a few highly admired people within a group can cause everyone in the group to care much more about the esteem of group members than they do about that of non-group members. See CHONG, supra note 52, at 59-60; Robert C. Ellickson, OrDer Without Law: How Neighbors SetTle Disputes 237-38 (1991).

${ }^{77}$ See supra notes $5 \mathrm{I}-58$ and accompanying text. 
esteeming others is a valuable "consumption good." A person deprived of this good - who finds no one in the world worth esteeming - is far less happy than one who has located a small collection of worthy souls. Nor is an individual who esteems twenty others necessarily poorer than someone who esteems only ten others to the same degree. To the extent that esteem is not costly, ${ }^{78}$ there is no reason to free-ride by withholding esteem from others. Instead, group members tend to allocate esteem in a way that brings them some return by rewarding those who contribute materially to group welfare and, at a secondary level, by rewarding those who allocate esteem in a manner that benefits the group. Imagine, as an analogy, that people have a kind of currency that is useless except for making group members feel better. It would be irrational to keep the currency or to distribute it randomly; one might as well provide it as a reward for those who contribute to group welfare and withhold it to punish those who do not.79

Departing briefly from an economic description of human behavior, I can state the point in more realistic psychological terms. "Thinking well of others" is often reflexive rather than deliberate. People who might free-ride on material payments tend not to free-ride on esteem "payments" because they reflexively admire and respect those who benefit the group. Imagine, for example, a chessmaster, a person who not only intensely studies the game, but also socializes predominantly with others who do the same. Taking egoism seriously means that this person will consider chess-playing ability to be an important measure by which others can be judged. Individuals elevate the importance of those traits or skills that they possess. ${ }^{80}$ This process helps the individual secure self-esteem. But a consequence of thinking that a particular trait is desirable is to esteem others who possess the trait and to

78 There may be costs to thinking well of others, but probably only when one grants very high levels of esteem. First, if one has a relative preference for obtaining a particular rank (for example, being a top violinist), esteeming many others may mean conceding that one has not achieved the rank one desires. See generally McAdams, supra note 59, at 7-26 (describing analyses of relative preferences in which one derives pleasure from another's consumption level in relation to one's own). For most individuals, however, it is still costless to believe that a limited number of others are exemplary in some way, either because one can still believe oneself superior to them or because one's relative preference is merely to be in the top tier. Similarly, there may be a cost in deciding how much esteem others merit. But this "decisional cost" itself may be zero if it is merely the by-product of the ego-enhancing process of valuing one's own qualities and of the information picked up about others in the course of daily life. (Of course, because this decisional cost is not always zero, people use "proxies" to allocate esteem.) Finally, a cost may be incurred in expressing esteem. (In some circumstances, esteem is inferred without expression, but only because esteem is sometimes expressed under those circumstances.) But I would make the same argument for expression that I do for esteem: people have a preference for expressing their beliefs, and thus the smile, gesture, or phrase that expresses esteem, within limits, is simply not a cost. Some commentators explain voting in this manner. See infra note 217 .

79 A group may also formalize the awarding of intra-group status by giving awards, special titles, or privileges. The abundance of such external tokens of esteem testifies to their success.

80 See supra note 75 . 
esteem them in relation to how much of the trait they possess. It is neither plausible nor coherent for the chessmaster to withhold esteem from other people who excel in chess. Barring an overshadowing negative trait, an individual will more or less automatically esteem others who have the traits the individual most values in herself, or the traits the individual would most like to acquire for herself.

Frequently, people reflexively esteem traits or behaviors that increase the welfare of the group. A player's success at chess tournaments raises the prestige of the chess club to which she belongs and earns her esteem within the club. A soldier whose skill or effort saves the lives of his fellow squad members earns their esteem. Moreover, if one who is known to value a particular trait withholds esteem from those who possess it, she risks appearing envious and losing the esteem of others. ${ }^{81}$ Especially within a group of people who desire a particular trait, refusing to esteem the trait (or at least to appear to esteem it) calls into question the dissenter's commitment to or understanding of shared values. Of course, some members may nonetheless be envious and refuse to provide esteem. But since esteem is at least partially reflexive, there is less than complete free-riding in allocating esteem, and the group can achieve a significant level of coordination.

Sociological evidence supports the theory that socially connected groups allocate esteem to overcome collective action problems. Socially connected groups, as I have defined them, consist of relatively small numbers of people who know each other. Sociologists have long been interested in how, within larger groups in society, "norms" arise as an important decentralized mechanism of social control. ${ }^{82}$ Esteem allocation, it turns out, provides the necessary micro-level explanation for social norms; the functioning of social norms, in turn, demonstrates the full power of intra-group cooperation.

Although economically inclined theorists have mostly ignored norms, one important exception is Robert Ellickson. In Order Without Law, ${ }^{83}$ Ellickson summarizes and supplements the empirical literature on the success of norms in regulating individual behavior. ${ }^{84}$ Ellick-

\footnotetext{
81 See McAdams, supra note 59, at 79-80.

82 See Mrchael Hechter, Principles of Group Solddarity 40-58 (1987); William J. Goode, The Celebration of Heroes 204-34 (1978).

83 See ELLickson, supra note 76. Other notable exceptions are GEORGE A. AKERLOF, AN ECONOMIC ThEORIST'S BooK of TALES 95-97 (1984); and Robert D. Cooter, Structural Adjudication and the New Law Merchant: A Model of Decentralized Law, I4 INT'L REv. L. \& ECoN. 215, 224-27 (1994).

84 Ellickson defines norms as one of the five types of "rules" that comprise a system of social control. Rules are categorized based upon the source of both the "rules of behavior and [the] sanctions that back up those rules." Ellickson, supra note 76, at 126. First-party control comes from within the actor and is enforced by self-sanction; second-party control is exerted by the other party with whom the primary actor is dealing and is enforced by personal self-help. Norms are one example of third-party control. They emanate from what Ellickson calls "social forces" and are enforced by non-hierarchical third-party enforcers. See id. at 131. The other sources of third-
} 
son's empirical contribution is his study of norms that govern the resolution of various disputes over livestock between neighbors in Shasta County, California. ${ }^{85}$ Like other social norms that arise within "closeknit groups," the Shasta County norms are a means of enhancing group welfare. The norms are a non-legal means by which the group facilitates desirable collective action. ${ }^{86}$ To some degree, what Ellickson and others identify as efficient norms are enforced by reciprocity between neighbors who expect to interact indefinitely, and the norms are therefore explicable in material terms. ${ }^{87}$ But the unique contribution norms make to cooperation - the additional power of norms beyond reciprocity - is third-party enforcement. ${ }^{88}$ What Ellickson has in mind are sanctions administered not by the immediate "victim" of a norm violation, but by "friends, relatives, gossips, vigilantes, and other nonhierarchical third-party enforcers." 89 Third parties sanction - by gossip, scorn, ostracism, or physical retaliation - those who violate the norms or informal rules of the group. ${ }^{90}$

My point, however, is that this informal third-party enforcement cannot exist without the desire for esteem. There is no material incen-

party control are organizations, which provide organizational rules and sanctions, and government, which provides legal rules backed by state enforcement. See id.

85 Ellickson studied disputes over damages from cattle trespass, allocation of the costs of boundary fences, and damages from automobile accidents caused by cattle wandering onto highways. He found that the first two classes of disputes (but not the third) are resolved by social norms that arise independently of and differ from legal rules. See id. at 40-I03.

$86 \mathrm{See}$ id. at 167 . Ellickson also reviewed studies that demonstrate the effectiveness of norms both in the whaling industry in the r8th and rgth centuries and among orchard owners in Washington state. See id. at I89, I91-206. He concludes that "members of a close-knit group develop and maintain norms whose content serves to maximize the aggregate welfare that members obtain in their workaday affairs with one another." Id. at 167 (emphasis omitted).

87 The enforcement mechanism for reciprocity is personal self-help. For example, when his neighbor fails to cooperate in controlling cattle trespass or contributing to boundary fences, a rancher may withhold some favor he usually grants, detain trespassing cattle, or engage in mild physical retaliation. See Ellickson, supra note 76, at 57-59, 79-8I. Ellickson labels the strategy these neighbors employed "even-up." It is a more complex form of reciprocity than tit-for-tat, applicable to a wider variety of circumstances. See id. at 225-29.

88 I am relying on Ellickson's definition of norms as a means of third-party, not reciprocal, control. Robert Cooter, on the other hand, implies that norms add to reciprocity only because individuals "internalize" certain obligations of behavior. See Cooter, supra note 83, at 22 r. Like Ellickson, I categorize internalization of norms as "first-party" or "self" control and conceive social norms as an independent form of "third-party" control. See Ellickson, supra note 76, at 126 n.8, 243-46. The difficult question is why this third-party enforcement exists. My claim is that such enforcement succeeds without internalization (or reciprocity) as long as individuals seek the esteem of others. Thus, while Cooter emphasizes the motivation of guilt - a negative feeling that exists even when others do not know of one's transgression, I emphasize shame - a negative feeling that exists only when others believe one has transgressed. See generally JEROME KAGAN, The NATURE OF THE CHILD 145-49 (1984) (discussing the development of distinct emotions of guilt and shame).

89 Ellickson, supra note 76 , at $\mathrm{r} 3 \mathrm{I}$ n.2I.

$90 \mathrm{See} i d$. at I31, 213-19. In Ellickson's taxonomy, social norms are enforced by "vicarious self-help." Id. at $\mathrm{r} 3 \mathrm{r}$. 
tive to obey norms unless there is a material cost attached to violating them. There is no material cost associated with violation unless someone imposes a material penalty. And there is no material incentive for others to bear the cost of inflicting such a penalty; after all, normenforcement is, for the group, a public good, and like all public goods, faces the problem of free-riding. ${ }^{91}$ Ellickson says that there is a secondary enforcement norm that compels people to punish those who violate norms and that those who fail to do so will also be sanctioned. But then the question arises why anyone would bear the cost of sanctioning those who failed to sanction a substantive norm violator. As Jon Elster argues, "People do not frown upon others when they fail to sanction people who fail to sanction people who fail to sanction people who fail to sanction a norm violation." 92 As one moves away from the original norm violation, "the cost of receiving disapproval falls rapidly to zero."93 Yet if the cost of refusing to enforce a norm at any level falls to zero, there is no reason for anyone to enforce the norm, and hence no reason for anyone to follow the norm. ${ }^{94}$

A concern for esteem as an end in itself, however, is sufficient to defend norm enforcement against the infinite regress Elster describes. Elster's argument assumes that mechanisms like gossip, scorn, and ostracism work only to signal who is to be subject to material sanctions and are only as effective as those material sanctions. But if disapproval itself exerts a real force, then the gossip, scorn, and ostracism are themselves sufficient to enforce norms; they punish the violator by lowering the esteem she receives from the community. ${ }^{95}$ In addition to

91 See ELSTER, supra note 27, at 132 n.I13. The individual reasons that either enough others will enforce the norm to ensure its effectiveness without her contribution or not enough others will enforce the norm to permit it to work even with her contribution. In either case, there is no material reason for her to enforce the norm.

92 Id. at 133 .

$93 \mathrm{Id}$.

94 Ellickson responds that " $[\mathrm{p}]$ erhaps the perception, or better yet the existence, of a few virtuous leaders or other committed third-party enforcers at the highest level of social control creates incentives for cooperative activity that cascade down and ultimately produce welfare-maximizing primary behavior." Ellickson, supra note 76, at 237 . Given his assumption, Ellickson is right. If most individuals perceive that certain members of the community are willing to inflict punishment on norm-violators notwithstanding the material irrationality of doing so, this core group can terminate the otherwise infinite regress and provide a foundation or "backstop" for the whole enforcement mechanism. Yet there is no reason for people to perceive the existence of such a group unless it actually exists. And Ellickson offers no explanation of why this core group of people ignore their own self-interest. Of course Ellickson may believe that such people are in fact pursuing a non-material self-interest in the form of status, but he does not make such an argument explicitly. See id. at 238 n.23 (noting "the elevated status of leaders and their special role in the enforcement of norms"). The desire for esteem is a more general and reliable backstop for norm enforcement than material self-interest.

95 Gossip transmits information on which people make reflexive esteem judgments. Elster has responded that expressing disapproval "requires energy and attention that might be used for other purposes" and that "[o]ne may alienate or provoke the target individual, at some cost or risk to oneself." ELSTER, supra note 27, at 133 . But others need not always express disapproval; some- 
this direct support, the desire for esteem may produce a secondary enforcement norm that requires material sanctions for violators of the primary norm. To avoid esteem punishment, individuals may have to bear some cost incurred by imposing material sanctions on norm violators. Thus, the considerable body of evidence that shows that social norms govern behavior further supports the significance of esteem motives, especially within socially connected groups.

In sum, individuals care particularly for esteem within socially connected groups. Even without a central authority, individuals tend to provide esteem to those who contribute to the welfare of such groups, and this process of esteem allocation facilitates wider social norms that bring about further cooperation. Of course, group members will still free-ride when their desire for material well-being outweighs their desire for intra-group status, but esteem allocation will ameliorate, if not eliminate, collective action problems.

\section{The Consequences of Intra-Group Cooperation: Inter-Group Conflict}

Intra-group cooperation increases inter-group conflict. Status is both an additional means of ensuring intra-group cooperation and a new end of intra-group cooperation, and it contributes in both ways to conflict between groups. Given that social groups often conflict over material resources, the desire for intra-group status means that group members will cooperate more effectively in such disputes, which ensures that groups will be more effective "combatants" whenever material conflict arises. More important, the very mechanism that facilitates greater intra-group cooperation will ensure a new form of conflict: competition for inter-group status. This latter result is the unfortunate and inevitable connection between cooperation and conflict.

Groups sometimes engage in zero-sum competition with other groups. A classic example is lobbying. When interest groups pursue what economists call "rent-seeking" legislation, such as farm subsidies and tax "loopholes," they seek merely to transfer resources from one group to another. ${ }^{96}$ Cartels similarly seek to extract the profits of noncompetitive pricing from consumers. For lobbying groups and cartels, individual contributions to the group's rent-seeking endeavor tend to be undersupplied; selfish members free-ride on the efforts of other members. But the cooperation secured by intra-group status produc-

times one is confident that by violating a social norm, she has lowered herself in the eyes of others. Further, because people enjoy expression as an end in itself, expressing disapproval is not always costly. One may alienate the target individual by disapproving of her - but that is the whole point. Rather than bear the cost of retaliating against those who express disapproval of one's norm violation, the rational actor often just obeys the norm in the first place.

96 See Jonathan R. Macey, Promoting Public-Regarding Legislation Through Statutory Interpretation: An Interest Group Model, 86 CoLuM. L. Rev. 223, 224 n.6 (I986). 
tion means that individuals contribute more heavily than they otherwise would toward their group's effort to win a conflict.97

Indeed, intra-group esteem production, and social norms based on such esteem, may provide the only explanations for the success of very large groups in lobbying despite powerful incentives for individuals to free-ride. Judge Richard Posner has conceded some uncertainty, for example, in explaining how farmers cooperate in legislative activities. ${ }^{98}$ I propose that the answer is the same for farmers as it is for the ranchers Ellickson studied in Shasta County. Although the occupational status of farmers or ranchers is not as observable as, for example, their race, it is one of the first things strangers detect about them. And within a geographic area, farmers and ranchers tend to be socially connected. Thus, farmers and ranchers have an interest in the status generally accorded their occupation and a means of inducing contributions to that status. Intra-group esteem allocation elicits material contributions to group material welfare, such as monetary contributions to lobbying efforts. For individual farmers and ranchers, the amount contributed may be small, but multiplication by a large number produces considerable political clout. ${ }^{99}$

There is a second reason intra-group esteem allocation increases group conflict. Individuals compete for esteem. One arena of competition is group status competition, in which individuals seek to produce status for themselves by raising the status of their groups. ${ }^{100}$ Under certain conditions, status is zero-sum, so that satisfaction of the status preferences of one group's members necessarily means non-satisfaction of the status preferences of another group's members.

In another article, I detailed the conditions under which relative preferences "inherently" conflict - that is, the circumstances under which the relative position is genuinely zero-sum. ${ }^{101}$ Although $\mathrm{I}$ focused there primarily on individual status-seeking, those conditions exist for social groups when members of different groups seek

97 Absent this effect, free-riding may be so great that the group never forms at all. Thus another reason intra-group status production causes more group conflict is that it ensures there will be more groups.

98 See Richard A. Posner, The Material Basis of Jurisprudence, 69 IND. L.J. I, I9 (1993).

99 Posner attempts to explain how lawyers cooperate in rent-seeking. See id. His most plausible claim for why individual lawyers bear the cost of organizing to produce cartel-protective legislation is that they believe such activities will make them better known, "thereby increasing the likelihood that [others] will refer cases to [them]." Id. at 20. But among the other lawyers a given lawyer knows, there are more compelling reasons for making referrals, such as the expectation of material reciprocity. Status, however, provides an explanation: when the material costs are low, lawyers "pay" organizers with status; and because organizers enjoy high status, lawyers seek to associate with them by giving them referrals.

100 By raising their group's status, individuals produce status for themselves in two ways. First, they share in the enhanced status their group enjoys. Second, for the reasons discussed above, they are rewarded with intra-group status for contributing to their group's welfare.

101 See McAdams, supra note 59, at 49-55. 
incompatible positions for their groups along some common, observable, and reasonably objective dimension. When these conditions do not hold, group status production is socially benign. ${ }^{102}$ But the conditions do hold, for example, when groups compare themselves along the "common dimension" of generalized social status ${ }^{103}$ and seek a position of superiority on that scale. ${ }^{104}$ Under such circumstances, social status is entirely relative. Investment in such zero-sum competition is therefore socially wasteful; the extent of the investment measures the size of the inefficiency. ${ }^{105}$ In particular, note the social waste of an obvious group optimizing strategy: one way to raise the status of one's group is to invest in lowering the status of other groups. ${ }^{106}$ Thus, the desire for esteem may lead to "subordination" as groups attempt to sabotage each other's general social position.

The status theory of cooperation and conflict may now be summarized. First, individuals seek, as an end, the esteem of others; in aggregate terms, they seek social status. Second, because socially connected group members are a key source of esteem, individuals will make material sacrifices on behalf of the group to gain intra-group status. Conversely, the group will reward such status to those who contribute to its welfare. Third, because another source of status is the larger society beyond one's social groups, one measure of group welfare is its status within society. Consequently, groups will use intra-group status "payments" to encourage members to contribute materially to inter-group status. Finally, because general social status is relative, one group can raise its inter-group status by lowering the status of other groups.

102 For example, even if groups $A$ and $B$ seek superiority over each other, there is no inherent preference conflict if group $A$ members wish to be superior in characteristic $X$ and group $B$ members wish to be superior in characteristic $Y$. The student bodies of two rival universities can both prosper, for example, if the students at the school that excels in football value only the sports comparison, while the students at the school that excels in placing students in graduate programs care only about the academic comparison.

103 There are certain characteristics that are widely valued in American society, such as wealth, education, and occupational prestige. See Roger S. MAson, Conspicuous ConsumpTION 108, I13 (I98I); Marcus Felson, Invidious Distinctions Among Cars, Clothes and Suburbs, 42 Pub. OpInIon Q. 49, 56-57 (r978). One can describe an individual's general social status by roughly summarizing these widely valued characteristics. See Mrhaly CsIKszentminalyI \& Eugene Rochberg-Halton, The Meaning of Things: Domestic Symbols and the SelF $3 \mathrm{I}$ (I98I) ("Status symbols] are in some ways a summary of all the salient characteristics of the self, a global measure of the owner's standing in the community."). Even if some people are indifferent to their relative wealth, education, or occupational prestige, they tend to be esteem-seekers and care about the social status these items earn for them.

104 Conflict exists in a variety of other circumstances as well. See McAdams, supra note 59, at 52-54. For example, conflict arises if one group seeks superiority and the other seeks equality.

105 See id. at 55-59. An exception is when the competition encourages investment in a public good. See id. at 59-62.

106 Cf. Steven C. Salop \& David T. Scheffman, Raising Rivals' Costs, AM. Econ. Rev., May I983, at 267 (discussing strategies intended to increase costs for rival firms). 
The experimental data support the prediction of inevitable intergroup conflict. In the minimal inter-group paradigm studies, the mere categorization of individuals into arbitrary groups caused a significant bias in the evaluations subjects gave the members of other groups. Similarly, there was less cooperation in prisoner's dilemma games solely as a consequence of having groups play against other groups instead of having individuals play against individuals. And in commons depletion games, individuals were more cooperative - less inclined to free-ride - if they were told they were being evaluated as a single group (against groups not then part of the experiment) than if they were told they were being evaluated as a member of one of two subgroups (in the experiment) facing the depletion problem. ${ }^{107}$

But group status competition matters because it exists outside the laboratory. Part II shows the real-world effect of these theoretical reasons for conflict. For now, consider again Ellickson's work on social norms. Ellickson adduces considerable evidence that the opposition of Shasta County ranchers to legislative proposals to close the range cannot be explained by additional material costs that the ranchers would bear. He concludes that the opposition is instead a function of symbolic politics: "The simplest explanation for the Shasta County cattlemen's opposition to a closed-range ordinance proposed for a rural area is that they regard a closure as a conspicuous kick in the teeth."108 Presumably, the answer is the same for the other side. Non-ranchers fight the political battle to establish symbolically their place in the social structure. If so, consider the full implications of this example: even when the law is materially irrelevant (because group norms supersede it), groups expend political resources solely for the purpose of symbolically establishing their superiority over each other.

The ranchers, of course, did not describe their motivation this way. The ranchers maintained a "folklore" that the range issue had dire material consequences. ${ }^{109}$ This use of folklore or ideology is understandable. People rarely esteem actions motivated expressly by a desire for status. ${ }^{110}$ Further, altruistic concerns or moral principles may lead us to condemn more strongly the pursuit of zero-sum social status (which necessarily lowers the welfare of others) than the pursuit of more con-

107 See supra notes $32-37,44-49$ and accompanying text.

108 Ellickson, supra note 76 , at 117 .

$109 \mathrm{See}$ id. at $117-18$. The ranchers believe the open range provides greater immunity from liability than it actually does. Ellickson says this misunderstanding leads to inaccurate decisions regarding care and insurance. See id. I argue, however, that the belief persists because it supports the group's production of status. See infra pp. 1058-60.

110 Even when one seeks status through positive accomplishments, admitting to a status motivation undermines one's status. See JoN ErSTER, SOUR GRAPES 66-69 (1983); McAdams, supra note 59, at 4I-44. The esteem of others, Elster argues, is something one cannot bring about directly, but only as the "by-product" of some other activity. See ELSTER, supra, at 66 ("N]othing is so unimpressive as behaviour designed to impress."). People still seek status, but they require a plausible non-status explanation for their conduct. 
ventional selfish ends (which do not necessarily harm anyone). The prevailing folklore provided the ranchers a more defensible reason for their opposition to the closed-range ordinance, one that allowed them to circumvent these obstacles to their pursuit of status.111

Consequently, even with material stakes, symbolism may motivate significant political action. Public choice theorists emphasize the material ends that interest groups seek, though they may concede the nonmateriality of purely symbolic matters (such as the recent controversy over removing the Confederate emblem from the State Flag of Georgia $^{112}$ ). Even when individuals articulate a material motive, however, they may actually be struggling over symbols and be motivated by status. Even if a closed range were clearly efficient, for example, ranchers might still oppose it for status reasons. ${ }^{113}$ If so, Ellickson's evidence for the efficiency of social norms demonstrates how the mechanisms that facilitate norms commonly lead to inefficient group conflict.

Consider now one extended example of intra-group cooperation and inter-group status: the problem of race discrimination. Indeed, discrimination is more than a simple "example" of the theory I have presented. Race discrimination best reveals the degree to which group status production is a powerful and pervasive fact of social life.

\section{A New Economic Theory of Race Discrmination}

Nobel Laureate Gary Becker pioneered what is now the prevailing economic theory of race discrimination. He began with the simple claim that people who discriminate act as if they have a "taste" for avoiding contact or association with members of other races. ${ }^{114}$ Dis-

111 Status production commonly involves such rationalizations. I explain the phenomenon more fully in the context of race discrimination. See infra Part II.B.2.c.

112 See Ken Foskett, Retreat on Issue a Sore Point for Governor, ATLANTA Const., Jan. 29, 1994, at Fx.

113 Even when individuals articulate a moral motive for their political positions, status competition may better explain the legal change sought or opposed. See, e.g., JOSEPH R. GuSFIELD, Symbolic Crusade: Status Politics and the american Temperance Movement I2-35, 44-50, I88 ( 1963$)$. My argument here thus falls in line with recent work on the psychology of procedural justice. Independent of outcomes, individuals care greatly about the procedures used in adjudicating disputes or allocating resources. According to psychologists, the explanation is that individuals care about the esteem they receive within their groups and adjudicatory procedures reveal that esteem. See E. Allan Lind \& Tom R. Tyler, The Social Psychology of Procedural Justice 230-37 (ig88); Tom R. Tyler, Why People Obey the LaW I73-76 ( $\mathrm{r} 990$ ). My point is to extend this insight from procedural to substantive rules: independent of the substantive effects of legal rules, individuals care about the symbolic effects those rules have on their social status.

114 See Gary BeCKer, The Economics of Discrimination 14 (2d ed. 1971) ("If an individual has a 'taste for discrimination,' he must act as if he were willing to pay something, either directly or in the form of a reduced income, to be associated with some persons instead of others."); see also id. at I5 ("Discrimination is commonly associated with disutility caused by contact with some individuals .....). 
crimination is thus defined as an act by which one seeks to avoid this undesired association. ${ }^{115}$ Although there are alternative economic explanations for discriminatory behavior, 116 this "associational preference" model has dominated the law and economics discussion of discrimination.117 Based on this model, Becker argued that unfettered market competition would tend to drive out discrimination. ${ }^{118}$ In turn, other economic theorists contend that, within a free market, laws prohibiting race discrimination are unnecessary and inefficient. ${ }^{119}$

115 Becker uses a "discrimination coefficient" to describe the degree to which individual market actors discriminate:

The money costs of a transaction do not always completely measure net costs, and a [dis-

crimination coefficient] acts as a bridge between money and net costs. Suppose an em-

ployer were faced with the money wage rate $\pi$ of a particular factor; he is assumed to act

as if $\pi(\mathrm{r}+d \mathrm{i})$ were the net wage rate, with $d \mathrm{i}$ as his [discrimination coefficient] against

this factor.

Id. at $\mathrm{I4}$. Becker provides a similar description of co-worker and customer discrimination, see id. at 14-15, and uses a "market discrimination coefficient" to measure differences in market wage rates or other prices due to discrimination, $i d$. at $17-18$.

116 The model of "statistical discrimination" claims that race is only a proxy for other qualities people care about. See Richard A. Epstein, Forbidden Grounds: The Case Against Employment Discrimination Laws 33-35, 40-41 (1992); Edmund S. Phelps, The Statistical Theory of Racism and Sexism, 62 AM. ECON. REV. 659, 659 (1972). Without more specific and costly information about individuals, discriminators assume that each member of a category has the average qualities of others in that category. Thus, white employers who discriminate are merely drawing rational statistical inferences about individual blacks given the cost of acquiring more specific information. Information costs do not, however, explain the racial animus that Becker's theory addresses; for example, they do not explain white supremacists' violence against blacks. Further, the idea of race as a proxy is inconsistent with Jim Crow definitions of race according to factors that were not at all observable. See infra p. I042. My claim is not that statistical discrimination does not exist but that we require a different theory for the paradigmatic case of racial animus.

117 " $[\mathrm{B}] \mathrm{y}$ increasing . . . contact . . . trade imposes nonpecuniary, but real, costs on those members of either race who dislike association with members of the other race." POSNER, supra note 3, at 65I. Similarly, Epstein's characterization of discrimination as a "refusal to deal" reflects a model in which discriminators seek to avoid association with members of other races. EPSTEIN, supra note I16, at 29-30; see also Harold Demsetz, Minorities in the Market Place, 43 N.C. L. REV. 27I, 27I (1965) (equating "discrimination against" with an "aversion to association" with). An important but under-recognized exception (to which $I$ am indebted) is George A. Akerlof, Discriminatory, Status-Based Wages Among Tradition-Oriented, Stochastically Trading Coconut Producers, 93 J. PoL. Econ. 265, 265 (1985). See infra pp. 1064-69.

118 See BECKER, supra note I14, at 35-37; see also Jennifer Roback, Southern Labor Law in the Jim Crow Era: Exploitative or Competitive?, 5I U. CHI. L. Rev. Ir6I, 1163 (1984) ("Becker's argument that discrimination is unprofitable to the discriminators and should eventually disappear from a competitive market setting is widely accepted." (footnote omitted)). One might charge that Becker's model is proved wrong by the continued existence of discrimination. Epstein responds that little discrimination remains and that what does remain is likely to be desirable, based on efficiency considerations omitted in Becker's analysis. See EPSTEIN, supra note 116, at $47-78,9$ r.

119 See Epsten, supra note 116 , at 9, 12; Demsetz, supra note I17, at 271, 275-93; Richard A. Posner, An Economic Analysis of Sex Discrimination Laws, 56 U. CHI. L. REv. I311, 1312 (1989) (speculating that sex discrimination law has diminished women's welfare); Richard A. Posner, The Efficiency and the Efficacy of Title VII, 136 U. PA. L. Rev. 513, 514 (1987) [hereinafter Posner, Title VII]. 
Many have questioned and criticized this economic analysis of discrimination. Yet legal criticism has generally taken one of two forms, neither of which offers an alternative economic theory of discrimination. The first accepts arguendo the starting point of the theory that discrimination is "non-association" - and then challenges the economic implications Becker and others draw from this model. ${ }^{120}$ A second group of critics, including critical race theorists, feminists, and others skeptical of economic analysis, rejects not only the non-association description of discrimination, but also the entire method of economics. ${ }^{121}$ Thus, critics of Becker's model have generally not been interested in using economics to develop a comprehensive alternative theory. ${ }^{122}$

This lack of interest is unfortunate. The economic theory of discrimination as non-association fails not because it employs the economic method, but because it is not sufficiently faithful to that method. Perhaps what seems so barren about the application of the economic method in this context is that it seems to require overlooking what many regard as the central realities of race discrimination: discrimination produces for its practitioners a gain beyond the mere avoidance of association, and discrimination victims suffer not just material harm, but also degradation. ${ }^{123}$ In contrast, the alternative economic theory I offer shows such facts to be central to evaluating the efficiency of anti-discrimination laws.

120 Thus, some theorists have argued that, even under Becker's model, competitive markets can perpetuate discrimination, see, e.g., Cass R. Sunstein, Why Markets Don't Stop Discrimination, 8 Soc. PHIL. \& PoL'y 22, 22 (I9gI), and that the laws against discrimination are efficient, see, e.g., John J. Donohue III, Is Title VII Efficient?, I34 U. PA. L. Rev. I411, 1412 (1986) [hereinafter Donohue, Title VII]; John J. Donohue III, Prohibiting Sex Discrimination in the Workplace: An Economic Perspective, 56 U. CHI. L. Rev. 1337, 1347-48, 1366-67 (1989) [hereinafter Donohue, Prohibiting Sex Discrimination].

121 See, e.g., Mary E. Becker, Needed in the Nineties: Improved Individual and Structural Remedies for Racial and Sexual Disadvantages in Employment, 79 GEO. L.J. I659, 1663 (1991); Richard Delgado, Rodrigo's Second Chronicle: The Economics and Politics of Race, gr Mich. L. REV. II83, II88-93, II95-97 (I993).

122 A partial exception is John J. Donohue III \& James J. Heckman, Re-evaluating Federal Civil Rights Policy, 79 GEo. L.J. I713, I728-29 (1991). The authors briefly propose an alternative to Becker's model in which race discrimination is supported by coercive social norms and universal belief in the inferiority of blacks. See also J. Hoult Verkerke, Free to Search, I05 HARV. L. REV. 2080, 2090-93 (1992) (discussing the economic importance of coercive social norms and reviewing Rrchard A. Epstein, Forbidden Grounds: The Case Against Employment DISCRIMINATION LAWS (1992)). Neither work, however, explains the intra-group cooperation necessary for discriminatory norms to function or the existence of racist beliefs.

123 Gary Becker, for example, makes the first point implicitly by defining discrimination solely as a means of avoiding a psychic "cost" one suffers from association. See BECKER, supra note $\mathrm{I14}_{4}$, at $\mathrm{I}_{4}-\mathrm{I}_{5}, \mathrm{I}_{53}$. The harm of discrimination is simply the loss of the benefit economic trades would have created, a loss shared by both discriminators and victims. See id. at 29-30; PoSNER, supra note 3, at 65I. Epstein exemplifies the second point. In Forbidden Grounds - a 500-page, purportedly exhaustive attack on the laws that prohibit employment discrimination - there is no mention of the rich literature on the psychological harms of racism. 
This Part proceeds in three sections. Section A critiques the associational preference model. I argue that the theory fails to explain a wide variety of empirical data on race-motivated behavior. Discriminatory individuals do not object to all forms of association with the targets of their discrimination, and race affects the behavior of some individuals well beyond what can be explained by a distaste for association. Section B offers an alternative economic account - a statusproduction theory of race discrimination based on the theory of intragroup cooperation and inter-group conflict that I developed in Part I. This theory better explains the behavioral evidence. Section $C$ discusses two implications of the status-production model, which mark considerable departures from Becker's model: first, race discrimination may persist in the face of market competition; and second, race discrimination represents a market failure similar to unregulated theft, one that may justify coercive restraint of private status "confiscation." Throughout this Part, I concentrate on race discrimination, and within that category, I primarily address discrimination by whites against blacks. Although I believe the model has a wider application, for now the discussion is more profitably focused on an intensive study of one example.

\section{A. Empirical Failures of the Associational Preference Model of Discrimination}

Notwithstanding the popularity of the associational preference model, it does not adequately explain discriminatory behavior. In particular, the model has trouble accounting for patterns of behavior during the Jim Crow era of segregation, which is precisely when and where we most need a theory of animus-based racial discrimination. Regarding this era, the associational preference model is both overand underinclusive, predicting both more and less racially discriminatory behavior than we actually find. The only way to force the model to fit the data is to posit a large, unwieldy set of associational preferences quite in tension with the reductive method of economics.

I. Overinclusiveness: The Prevailing Model Overpredicts Discrimination. - The desire for non-association initially seems a sensible explanation of the separatist behavior of whites in the Jim Crow South, as exemplified by their enforcing separate seating in restaurants and on common carriers, separate rest room facilities and water fountains, and separate hotel accommodations, hospitals, and schools. Yet white behavior, even in the Jim Crow South, was far from universally separatist. Southern whites, including whites who frequently practiced discrimination, sometimes seemed indifferent to associating with blacks. ${ }^{124}$ Two examples are particularly powerful.

124 See GunNar MYrdal, AN AMERrCAN DILEMMA 590 (i944) ("[T]he more general allegation that there is an inherent repulsion to personal intimacies and physical contact between the two 
First, southern whites commonly employed black domestic workers in their homes. ${ }^{125}$ If the desire to avoid contact with blacks explains segregation, then one would not expect whites to associate with blacks by hiring them within the home; living with another person is a far more intimate and extended association than, for example, sharing a seat on a bus. ${ }^{126}$ To the contrary, whites were quite willing to boast of employing live-in black women servants and often allowed such servants considerable control in rearing white children. ${ }^{127}$

The second example involves an even more intimate association: sex. Notwithstanding a general miscegenation taboo, white men in the South frequently engaged in sexual relations with black women. ${ }^{128}$ These liaisons constituted a willingness to associate intimately with blacks on the part of the very whites whose discriminatory behavior we seek to explain. ${ }^{129}$

One might respond to these examples that Becker only claims that discriminatory whites bear a non-monetary cost from associating with blacks. He does not claim that this cost is always prohibitive. Whites will associate whenever the benefits of a particular association outweigh the costs. Whereas sitting on a bus or at a lunch-counter is a milder form of association than the two examples considered above, the benefits that accrue from domestic services or sexual intimacy may be entirely absent from the milder forms of association. Thus, the benefits of employing black domestic help or engaging in sexual activi-

[racial] groups is unfounded."); see also C. Vann Woodward, The Strange Career of Jim Crow 3I-32, 42 (3d ed. 1974) (stating that, during the two decades after Reconstruction and before Jim Crow segregation, contact between the races was considerable).

125 See, e.g., John Dollard, Caste and Class IN a Southerntown 96 (I937) (reporting that in Southerntown, the pseudonym Dollard gives to the town in which he lived and studied racial relations in the early I930s, " 97 percent of the women listed under 'domestic and personal service' [in the census] are Negro women").

126 See MYRDAL, supra note 124 , at 590, 652 (noting "the acceptability [among whites] of physical contact with favorite servants" and stating that "the Negro maid knows the life of her white employer as few white persons know it").

127 See Patricia H. Collins, Black Feminist Thought 7 (I99I); Myrdal, supra note 124, at 597. Indeed, black women sometimes nursed white infants. See WoODWARD, supra note 124, at 42-43; More Slavery at the South, INDEPENDENT, Jan. 25, I912, at 196-200, reprinted in BLACK WOMEN IN WhIte AMERICA 227, 227 (Gerda Lerner ed., I972) (under the title I Live a Treadmill Life).

128 Such relations began during slavery. See BELL HOOKS, AIN'T I A WOMAN 33 (I98I); JACQUELINE JONES, LABOR OF LOVE, LABOR OF SORROW 37 ( $\mathrm{rg85}$ ). Writing during the Jim Crow era, Dollard suggested that "many, if not most, southern boys begin their sexual experience with Negro girls." DOLLARD, supra note 125, at 139; see also W.E.B. DuBoIs, DarkWATER I63-86 (I920) (discussing sexual relations between white men and black women).

129 See DOLLARD, supra note 125 , at 143 ("A Negro woman reported with indignation that a number of white men in Southerntown have Negro mistresses. . . [S]ome of these . . . are the ones who insist on segregation."); KENNETH B. CLARK, DARK GHETTO 68-69 (I965) (noting that the civil rights movement put social pressure on "any Negro woman who [was] known to be the mistress of . . . a segregationist . . . to break that relationship"). 
ties with black women might have outweighed the associational costs. ${ }^{130}$

Although the benefits of some associations are greater than others, there is still something implausible about Becker's model. In his model, some whites are so repulsed by blacks that they find their mere presence in public places intolerable for even a brief time, yet they are not sufficiently repulsed to avoid hiring blacks to work in their homes, nor to refrain from seeking sexual relations. In the case of domestic workers, it is true that the wages for black women were lower than those for white women. ${ }^{131}$ Yet in the segregated South, whites were generally poorer than in other parts of the country, and most domestic workers were black. Nonetheless, it was considerably more common for southern whites than for whites in other regions to employ domestic workers and more common for the employment to be full-time. ${ }^{132}$ If segregationist whites wished to avoid contact with blacks, one would expect to observe the opposite relationship. ${ }^{133}$ Similarly, if association occurred because most whites could not afford white labor, one would expect - contrary to the facts - that wealthier southern whites would not have hired black nannies. Finally, while the power of white men to compel black women to engage in sexual activity helps explain the frequency of this interaction, there remains an incongruity between the image of married white men's abhorring the most fleeting public associations with blacks, yet seeking out long-term sexual associations with black women. ${ }^{134}$ Given the spousal exception to rape laws then in effect, ${ }^{135}$ married men were guaranteed a means of sexual gratification. To choose a black mistress under these circumstances is simply inconsistent with a general preference for avoiding contact with blacks.

As a final example of the overinclusiveness of the associational model of discrimination, both in the Jim Crow era and today, consider discrimination on the basis of sex. One might expect that there is

130 Following RIChard A. PoSNER, SeX AND REASON 138-4I (1993), one could say that white men incurred considerably lower costs in obtaining sexual gratification from black women than from white women. To engage in sexual relations with white women, white men in the Jim Crow South usually had to assume the costs of marriage or the risks of extramarital sexual affairs (legal sanctions for rape or adultery, or extra-legal sanctions from a woman's male relatives). Regarding African American women, however, the law permitted no marriage to white men and in practice imposed no penalties for rape, while legal institutions permitted no private retaliation by blacks.

See Dollard, supra note 125 , at $\mathrm{I} 45, \mathrm{I} 5 \mathrm{I}$.

131 See MYRDAL, supra note I24, at 1086.

132 See id. at $284,1083-84$.

133 Indeed, Myrdal reports that black women fared better at getting domestic work in the South: in other regions, many whites "have a prejudice against using Negro women in their homes, partly because they believe them to be less dependable, partly because they shun the contact with an alien race." Id. at 1083 (emphasis added).

134 Regarding long-term affairs, see DuBoIs, cited above in note 128 , at I72.

135 See Susan Estrich, Real RAPE 72 (1987). 
enough in common between race and sex discrimination that a single economic theory could make some progress in explaining both. Indeed, Becker claims that his theory "can be applied to 'discrimination' and 'nepotism' in all their diverse forms," including discrimination against women. ${ }^{136}$ Yet there is something seriously amiss in describing discrimination against women as the result of a preference men have for avoiding association or contact with women. Nor can one easily redefine the discriminatory preference as somehow only applying to the workplace, for men who wish to exclude women from certain jobs may have no difficulty with, or may actually prefer, to see women serve in other capacities, for example, as secretaries.

In all of these examples of overinclusiveness, discrimination seems to result from the desire to avoid certain kinds of associations, not to avoid association per se. A better theory would explain what distinguishes the desired and despised associations.

2. Underinclusiveness: The Prevailing Model Underpredicts Discrimination. - The associational preference model also underpredicts discrimination. Race affected the behavior of whites beyond their seeking to avoid contact or association with blacks. If discriminatory whites sought merely to avoid associating with blacks, for example, why did they prohibit interracial marriage? In other respects, the associational preference theory explains laws mandating segregation. Without such laws, a white person with a strong associational preference against blacks might need to use public transportation, for example, only to find that blacks were dispersed throughout the train or bus seats. Jim Crow laws prevented involuntary associations in such circumstances. But southern whites had no reason to fear the possibility of involuntary marriages with blacks. Marriage is one form of association that individual whites could certainly avoid without the aid of a legal prohibition.

The explanation, of course, is that no individual white supported anti-miscegenation statutes to prevent herself (or more importantly perhaps, himself) from associating with blacks. The purpose was to prevent other whites from entering into such associations. ${ }^{137}$ Discriminatory whites acted to satisfy not just a desire to avoid certain associations with blacks, but a desire that other whites avoid them as well. Indeed, some of the most explosive and well-documented instances of racial violence occurred precisely because white men objected to associations (or perceived associations) between black men and white

136 BECKER, supra note II4, at II.

137 See MYRDAL, supra note 124 , at 587 ("Every single measure [of enforced segregation] is defended as necessary to block 'social equality' which in its turn is held necessary to prevent 'intermarriage."). 
women. ${ }^{138}$ Thus, there was significant race-based behavior not explained by the desire to avoid contact with others. ${ }^{139}$

The evidence of such "third party preferences" extends well beyond the taboos against interracial marriage and sexual relations between white women and black men. Whites in the Jim Crow South monitored each other for compliance with a wide range of social norms concerning race. Whites expected each other to observe taboos "against eating at a table with Negroes, having them in the parlor of one's house as guests, sitting with them on the front porch of one's home, and the like."140 One white southerner of the era told sociologist John Dollard that "[i]t made his blood boil . . . when he went North, to see Negroes riding in streetcars side by side with whites, to see them eating in the same restaurants, to see Negro men and white women together. It would have the same effect, he added, on any southerner."141

The failure of the associational preference model to predict these other norms is no minor omission. In the Jim Crow South, whites were subject to social sanctions and violence if they failed to abide by the customs of segregation, for example, by refusing to engage in the derogation of blacks. ${ }^{142}$ Dollard recounts how white outsiders - like himself - were subjected to indoctrination into the ways of racial cus-

138 See, e.g., ClARK, supra note I29, at 69; IDA B. Wells-BARNETT, ON Lynchings 5-12 (Arno Press 1969) (1892). We can reject the response that conduct aimed at other whites served merely to minimize undesired contact with blacks. Admittedly, forbidding whites to marry (or otherwise associate with) blacks made it less likely that whites would accidentally make contact with a black person through his or her white spouse (or friend). But this fact is not an adequate explanation of white-on-white coercion. A preference for non-association cannot explain the degree to which interracial social contact, especially between black men and white women, was such a central and emotionally charged matter. If the only point were to avoid associating with the black member of an interracial couple, whites should have found interracial couples more acceptable than all-black couples - the former included one person with whom it was acceptable to associate - and should have found a passing sexual affair less troubling than a long-term serious relationship. Yet segregationist whites found the idea of interracial couples abhorrent, and no less so when the relationship was fleeting. See CLARK, supra note I29, at 69; DOLLARD, supra note 125, at 165-66; MYRDAL, supra note 124, at 588 .

139 This violence in turn raises another example of the overinclusiveness of the associational preference model. Even violence requires a form of physical "contact" the discriminatory white is supposed to abhor. Lynchings were often very public affairs; sometimes hundreds or thousands of whites would flock to the scene. See, e.g., Arthur F. RAper, The Tragedy of Lynching 12 (I933). White spectators who crowded around protracted torture-lynchings apparently wished to avoid only certain kinds of contact or "association." See id. at 143-44.

140 DoLLARD, supra note I25, at 350-5I ("Any of these acts would imply social equality instead of social inferiority for the Negro.").

141 Id. at $45-46$.

142 See id. at 187 ("The white person in Southerntown has no more option about calling a Negro 'Mr.' than the Negro has to demand the title.'). Dollard reports the case of a "prominent white man in the state who had to meet a talented Negro woman from Southerntown on various occasions both in town and out of it" and who addressed her with the title "Mrs.' when they were away, but by her first name in Southerntown." Id. at 346 . 
tom. ${ }^{143}$ Usually, these attempts at indoctrination were successful, he notes, and caused whites who did not initially accept "southern views" of race relations to adopt them and to engage in the derogatory behaviors practiced by whites toward blacks. ${ }^{144}$ Those who refused to abide by such customs were themselves subjected to derogation. ${ }^{145}$

Another example of the underinclusiveness of the associational preference model is that it does not predict this customary derogation of blacks. Insulting behavior was an entrenched part of Jim Crow that manifested itself in countless petty ways, such as the custom of whites to address blacks, regardless of their age or education, by their first names, without benefit of titles such as Mr. or Mrs. ${ }^{146}$ In general, whites demanded deference and submissiveness from blacks. ${ }^{147}$ Mere desire to avoid association does not explain such behavior. ${ }^{148}$

Consider, finally, how the associational model harbors a crucial definitional ambiguity. The people to whom Jim Crow laws referred by racial terms such as "negro" were by no means certain. As many scholars have demonstrated, race is an imprecise, socially created category. ${ }^{149}$ There were putatively black people who "passed" as white ${ }^{150}$

143 See id. at I2.

144 Dollard observes:

When ['Yankees'] come down South ... they usually accept the social arrangements and become loyal white-caste members. A number of cases of this were pointed out, especially those of northerners who had come to do business in the South .... [Regarding one such person,] [i]t seemed very likely that he had to accept southern views because his social contacts and those of his wife and family were with whites; he could not stand out against the tremendous pressure of white sentiment; and further, he could advance his economic interests only by coöperating with the dominant group.

Id. at 48 .

145 "There are constant and potent pressures to compel every white person to act his caste rôle correctly." Id. at 49; see also id. at 46-48 (discussing the meaning and effectiveness of epithets whites use against whites who do not conform to racial norms). Dollard's black informants warned him to be careful not to treat them as he treated whites nor as he treated blacks in the North. See id. at 8.

$146 \mathrm{See} i d$. at I8I. In one town, southern white postal workers even effaced such titles on envelopes addressed to blacks. See NEIL R. MCMILLEN, DARK JourNey 24 (1989). In contrast, whites referred to each other with various titles of respect, $i d$. at 23-24, and blacks referred to whites with such deferential titles as "Mr.," "sir," or "boss." See DoLLARD, supra note I25, at I8I, 346. Similarly, whites permitted blacks to come to their house only at the back door, and whites typically summoned blacks from their dwellings by honking a horn. See id. at 46, 120 .

147 See DOLLARD, supra note 125, at 178-79; see also MCMILLEN, supra note 146 , at 23-28 (contrasting racial "etiquette" for blacks and whites in Jim Crow Mississippi).

148 A proponent of the associational preference model might claim that insulting behavior served merely to deter blacks from future association. Yet nothing in the historic literature I reviewed suggests that whites insulted blacks to deter unwanted association. Whites refused to give blacks titles of address and insisted that blacks use the back door whether or not the white initiated and desired the association.

149 See, e.g., F. James Davis, Who Is BzACK? I9-23 (I99I); Robert J. Cottrol, The Historical Definition of Race Law, 21 Law \& Soc'y Rev. 865, 865 (1988); Cheryl I. Harris, Whiteness as Property, IO6 HARV. L. REv. 1707, I737-4I (1993).

150 See, e.g., MYrdal, supra note 124, at 683-84; Patricia J. Williams, The Alchemy of RACE AND RIGHTS 223 (I99I); Harris, supra note 149, at I710-13. 
and people who considered themselves to be white although, by legal definitions, they were not. ${ }^{151}$ In saying only that people desire to avoid association with members of another "race," the associational model says nothing about why or how it is that individuals define race as they do. We are left with the nearly circular and highly unenlightening proposition that people discriminate to avoid associating with the people against whom they discriminate. ${ }^{152}$

3. Efforts to Preserve the Model Are Inconsistent With Economic Reductionism. - The associational preference model fails to explain the historic data concerning the Jim Crow South. However, perhaps one could modify the theory to account for the data. One could enlarge the number of associational preferences used to describe observed behavior and contract the scope of each preference. For example, in response to my claim that a preference for non-association is overinclusive, one might posit instead a number of discrete associational preferences: a preference for avoiding association with blacks in public transportation, another for avoiding use of the same rest room, several more for avoiding common use of motels, lunch counters, and so on. One could then account for the absence of discriminatory behavior in contexts such as domestic service and sexual relations merely by positing that no associational preference exists in these areas. One might similarly respond to my claim that the associational model is underinclusive. To explain white-on-white social coercion, one could assert an additional preference not to associate with members of one's own race who associate with members of another race. ${ }^{153} \mathrm{By}$ expanding the number of preferences, one can preserve the basic description of discrimination as a form of non-association. ${ }^{154}$ Race-based behavior can thus be portrayed as the product of a multitude of discrete associational preferences, including third-party associational preferences, that co-exist with discrete areas of associational indifference.

From an economic perspective, however, there is something obviously wrong with this manner of defending the associational model. Expanding the number of preferences is fundamentally contrary to the reductive methodology of economics. A parsimonious theory would

151 See Harris, supra note 149 , at 1739.

152 Racial ambiguity also intensifies the overinclusiveness problem. Given the lengths that some southern states went to in excluding from the "white" race people with only distant black ancestry, see id., one would suspect that the associational preference against Africans would be of unmitigated intensity. So why would whites who wished to exclude people who had any African ancestry from the white train car ever employ people of full African ancestry in their homes?

153 What is really required to explain the data is a more complex set of third-party preferences: a desire that members of one's race not associate with other races in public transportation, another that they not associate with other races by using the same rest rooms, another desire that they avoid association by using the same motel, lunch counter, and so on.

154 Even with this strategy, one cannot explain the derogation of blacks as the consequence of an associational preference. One could, of course, posit a discrete preference for disparaging blacks. 
explain the data of race-based behavior with a single preference. Few economists understand this point better than Gary Becker. Long after his discrimination work, Becker wrote persuasively of the need to avoid explaining behavior by differences in tastes and to assume instead the existence of similar stable preferences among consumers. ${ }^{155}$ Toward this end, he proposed a household "production function," 156 which posits that consumers allocate their time and other inputs to "produce" satisfaction of a few basic pleasures. For example, people do not have one preference for canned apples, another for electric can openers, and yet another for microwave ovens. Instead, people have a desire for nourishment (and perhaps another for culinary pleasure), and they "produce" satisfaction of this desire by combining a variety of goods with their own time and effort. The virtue of the latter approach is that it avoids explanations based on differences or fluctuations of taste and compels the theorist to search instead for explanatory variables that are observable and verifiable. ${ }^{157}$

Ironically, Becker's model of race discrimination exemplifies the very failings that his household production function was meant to correct. Under Becker's original model, one observes separatist behavior by whites and posits that they have a preference for non-association. There is no inquiry into what white consumers might be producing by such behavior. If different whites with identical wealth engage in different levels of discriminatory behavior, the associational preference model can only make the unfalsifiable claim that some whites have a greater taste for non-association than others. ${ }^{158}$ Responding to my arguments for over- and underinclusiveness by positing a separate preference for each kind of observed discriminatory behavior only compounds the problem and places even more explanatory weight on unobservable differences. A theory that can explain race-motivated behavior as serving a single preference is preferable to a fragmented associational preference model.

155 See George J. Stigler \& Gary S. Becker, De Gustibus Non Est Disputandum, 67 AM. EcoN. REv. 76,76 (1977).

156 Gary S. Becker, A Theory of the Allocation of Time, 75 Econ. J. 493, 495 (1965).

157 For example, if we say that people buy microwaves because they have a preference for microwaving food, we can explain the fact that people with identical wealth buy different quantities of microwave ovens only by saying that some people have stronger preferences for microwaves than others. The claim is unfalsifiable because no independent measure of consumer preferences exists except the observed behavior one seeks to explain. With the household production function, however, we can avoid such unfalsifiable explanations. We could predict, for example, that people with less leisure time for cooking (labor being one production input) will make greater use of capital intensive devices like microwave ovens.

158 Compare Stigler \& Becker, supra note 155 , at 89 ("[N]o significant behavior has been illuminated by assumptions of differences in tastes. Instead, they, along with assumptions of unstable tastes, have been a convenient crutch to lean on when the analysis has bogged down.") with BECKER, supra note II4, at I2I ("TT]he regional difference in market discrimination . . . must be 'explained' by a regional difference in tastes.'). 


\section{B. The Status-Production Model of Race Discrimination}

As an alternative to the associational preference model, I propose that we understand race discrimination as an especially virulent and pathological form of status production. Discrimination and racist behavior generally are processes by which one racial group seeks to produce esteem for itself by lowering the status of another group. The key to understanding this behavior is to perceive its subordinating quality. Status comes about by disparaging others, by asserting and reinforcing a claim to superior social rank. Under this view, the associational preference model is partly, but only partly, correct. One obvious way to express disrespect toward others is to refuse to associate with them. But non-association is over- and underinclusive because one can subordinate those with whom one associates and because, when non-association is used, it does not exhaust the means of subordination.

Observers of race relations have long noted the importance of status to discrimination. Commentators from the Jim Crow era, ${ }^{159}$ as well as modern sociologists and social psychologists studying race, ${ }^{160}$ have observed that discrimination produces status for its practitioners. John Dollard, a Jim Crow contemporary and a sociologist, reported that "the novelty in the South is that one has prestige solely because one is white."161 W.E.B. DuBois described the "public and psychological wage" earned by white workers solely from the social status of their race. ${ }^{162}$ Today, critical race theorists and other commentators insist on the importance of the appropriation of social status to an understanding of race discrimination. ${ }^{163}$ Yet this insight is more than a

159 See, e.g., MYRDAL, supra note 124 , at $59 \mathrm{I}$ ("W]hat white people really want is to keep the Negroes in a lower status."). "П]n the three-cornered tension among upper class whites, lower class whites, and Negroes, the two white groups agree upon the Negroes as a scapegoat and the proper object for exploitation and hatred. White solidarity is upheld and the caste order protected." Id. at 598; see also Frank Tannenbaum, Darker PhaSes OF the South 8-9 (1924) (examining the "fear of changing status").

160 These social scientists reject non-instrumental theories that locate prejudice in individual cognitive or personality processes. See David T. Wellman, Portraits of White Racism 24-26, 48-62 (2d ed. I993); Herbert Blumer, Race Prejudice as a Sense of Group Position, I PAC. Soc. REv. 3, 3 (1958); Lawrence Bobo, Group Confict, Prejudice, and the Paradox of Contemporary Racial Attitudes, in Elmminating RAcism 85, 95-98 (Phyllis A. Katz \& Dalmas A. Taylor eds., I988); Riia Luhtanen \& Jennifer Crocker, Self-Esteem and Intergroup Comparisons: Toward a Theory of Collective Self-Esteem, in Social Comparison, supro note 75, at $211,225$.

161 Dollard, supra note I26, at I73-74. Professor Dollard observes:

The gain here is very simple. . . [D]t consists of an illumination of the image of the self, an expansive feeling of being something special and valuable. It might be compared to the illusion of greatness that comes with early stages of alcoholization, except that prestige is not an illusion but a steadily repeated fact.

Id. at I74.

162 W.E.B. DuBoIs, Black RECONSTRUCTION IN AMERICA 700 (1935).

163 See, e.g., David R. Roediger, The Wages of Whiteness I3 (rggr); Derrick Bell, White Superiority in America: Its Legal Legacy, Its Economic Costs, 33 VrLL. L. Rev. 767, 774 (I988); 
criticism of existing theory: it is the starting point of a new economic account of race (and other forms of) discrimination - an account that succeeds as a social science theory because it predicts and explains much of what we observe concerning race.

I. The Economics of Racial Status Production. - Only visible distinctions affect the level of esteem one receives from strangers. Consequently, individuals care greatly about the status associated with their visible characteristics. To produce status, one can invest in acquiring visible traits that others consider desirable, ${ }^{164}$ or one can invest in making others consider one's existing visible traits desirable. One may pursue this latter strategy directly, by accumulating accomplishments that enhance the trait's status, or indirectly, by lowering the status accorded the traits of others. ${ }^{165}$ When members of a group pursue the indirect production strategy of lowering the status accorded other traits, they engage in "discrimination."

Race defines a "shared-trait" group because it is constructed around observable traits. Race discrimination is thus a means by which people who share certain roughly similar and observable traits that come to be known as "race" produce social status for themselves. Status production does not explain why the particular visible characteristics we associate with race become important to status production, but once they are salient, the theory explains why they remain important. ${ }^{166}$ Not only do people compete for esteem by investing in subordination of previously defined groups, but people invest in preserving group boundaries to maintain their position in a high-status group. ${ }^{167}$

Kimberlé W. Crenshaw, Race, Reform, and Retrenchment: Transformation and Legitimation in Antidiscrimination Law, IoI HARV. L. REV. I33I, I38I (I988); Harris, supra note 149, at I758.

164 For example, individuals seek to acquire and display "status symbols" such as consumer goods that demonstrate economic success or fashionable taste. See McAdams, supra note 59, at 38-44. Or one might invest in acquiring physical features that will enhance status. See, e.g., Body Work, U.S. NewS \& WORLD REP., Oct. I7, I994, at 15, 15 (observing that Americans spent over $\$ 1.7$ billion in cosmetic surgery in I993).

165 When socially connected groups share a visible trait, they can coordinate either form of status production for the shared trait.

166 Race is a category constructed along the lines of observable traits, but not determined by them. See supra p. 1042. Barbara Fields observes, therefore, that "race" cannot explain "why people of African descent have been set apart for treatment different from that accorded to others" because "race is just the name assigned to the phenomenon" of categorization. Barbara J. Fields, Slavery, Race and Ideology in the United States of America, NEw LEFT REv., May/June I990, at 95, 100. The proxy effect of observable traits does not explain which physically observable features will come to dominate the production of status (why not left- versus right-handedness?). Which observable features determine racial distinctions is a matter of historical circumstances. For Africans in America, race arose as part of the ideology of slavery. See id. at Ior; Harris, supra note I49, at I715-21. Once the categories are in place, however, status production explains their tenacity. Thus, once the idea of "whiteness" arose, white southerners protected their status by adopting stringent standards for being white, and immigrants struggled to gain the status of being white. See Harris, supra note I49, at 1744 \& n.r62; ROEDIGER, supra note I63, at I33-63.

167 See infra note 182. 
This model of race discrimination raises two questions. First, given that discrimination is costly, how do whites, absent a central coercive force, prevent other whites from free-riding on each other's investment in the status of their shared trait? Second, how exactly does one inflict a status loss on another group?

(a) Overcoming the Free-Rider Problem. - In the manner described above, socially connected whites allocate esteem to overcome the problem of free-riding. ${ }^{168}$ Through "esteem payments," a socially connected group can reward (or punish) those who make (or fail to make) contributions to group status. For socially connected whites, the status accorded whiteness is an important determinant of the group's status among strangers. We can expect socially connected whites to use esteem payments to ensure investment in racial status production.

The necessary condition for this racial status production is an overlap between socially connected and racial (shared-trait) groups. In the United States, the "overlap" of socially connected and racial groups is not complete. Obviously, not all whites are socially connected. If many socially connected groups comprise a common-trait group, each subgroup may have an incentive to free-ride rather than to contribute to the enhancement of the common trait's external status.

Unlike the problems experienced by unconnected individuals sharing a common trait, however, this free-rider problem can be solved. The empirical evidence of real-world cooperation suggests that subgroups - including military units in war and black churches in the civil rights movement - manage to avoid complete free-riding. ${ }^{169}$ Three factors permit white groups to enjoy similar success. First, geography provides a way to subdivide individuals. Much of the benefit one receives from possessing a trait others esteem, and much of the cost one incurs from possessing a trait others disdain, comes from individuals within the geographic area in which one lives and works. Given this geographic limit, some people will live in places where it is possible for everyone who shares a common trait to be socially connected. In small towns, for example, all the people of a given race may know each other personally or know of each other by reputation. ${ }^{170}$ If so, the socially connected group can achieve what is, for it, an optimal or nearly optimal investment in the status of the shared trait.

Second, even in a larger geographic area, whites as a group may be "privileged" in that some group member benefits sufficiently from the

168 See supra pp. 1020-28.

169 See supra pp. 1018-19.

170 The theory of status allocation thus explains higher levels of discrimination in smaller towns: individuals who fail to contribute to maintenance of the external status are easily identified and punished. See DollarD, supra note 125, at I5. 
public good to be willing to bear the entire cost of providing it. ${ }^{171}$ In the case of race, the "member" is a subgroup of socially connected whites who benefit sufficiently from racial subordination that they are willing to bear the costs of discriminating regardless of what other whites do. Particularly where members of a socially connected group have few other options for status production, they benefit from some investment in raising the value of their shared trait. ${ }^{172}$ Because these groups are socially connected, they can use intra-group esteem to elicit even very high-stakes contributions to group status.

Finally, social norms can arise among a collection of socially connected groups. Socially connected groups, as I have defined them, are quite small. An individual is likely to belong to many socially connected groups. Her reputation will extend beyond her own socially connected group to the groups that share members with her groups. Thus, if at least one white subgroup finds it productive to invest in raising the status of the shared trait, it may be able to pressure other white groups to do the same. Concerned with their reputations among "nearby" groups, members of these other subgroups may be pressured into investing in racial status production. Out of this process may arise social norms of discrimination that transcend individual subgroups. Indeed, when Ellickson says norms arise within "close-knit groups," he has in mind communities that include numerous groups that are socially connected according to my definition. ${ }^{173}$ The evidence suggests that norms can, at this level, induce cooperative action. ${ }^{174}$ Discriminatory norms are the final means by which sharedtrait groups control free-riding.

In sum, absent a central coercive authority, substantial overlap of shared-trait and socially connected groups is sufficient to make subordination of other groups an effective means of producing status. Before proceeding, however, we must ask why such overlap occurs. Obviously, history and culture produce considerable stratification of socially connected and shared-trait groups. ${ }^{175}$ Yet part of the problem theorists have had in understanding racial and ethnic hatreds is discerning why these contingent factors seem to produce such permanent

171 See Chong, supra note 52, at $\mathrm{I}_{3}$. Even though a person cannot prevent others from freeriding on a public good, if the private benefits she obtains from such a good exceed her private costs, she will contribute to its provision.

172 The theory thus predicts higher levels of discrimination among low-status whites. See infra p. 1055 .

173 Ellickson, supra note 76, at $180-8 \mathrm{I}$.

174 To Ellickson's compilation of data on social norms, Chong adds that the civil rights movement of the Ig6os succeeded because it managed to combine the efforts of various pre-existing socially connected groups, such as black churches. See CHONG, supra note 52, at 35-36.

175 Race is the obvious example: because dark-skinned Africans were brought to America as slaves, socially connected groups were highly stratified by skin color. Immigration provides other examples: a minority culture may, for a time, maintain distinctive language and clothing so that its socially connected groups also share easily discernible traits. 
distinctions, and why such contingent factors so frequently exist. There is, unfortunately, an economic force that works toward overlap after historic or cultural reasons should have had time to dissipate. A shared-trait group's potential for status production ${ }^{176}$ is a resource to exploit, and a socially connected group offers the way to exploit that potential. In other words, when individuals can choose between socially connected groups, one in which people share a common visible trait has a comparative advantage for status production over one in which people do not share a common visible trait. Consequently, it is not entirely accidental that groups tend toward the very overlap necessary to make status production viable. ${ }^{177}$

(b) Mechanics for Lowering a Group's Status. - The second question raised above is how members of one group can lower the status of members of another group. In general, one lowers the status of others by signaling, to them and to third parties, that one does not hold them in high esteem. ${ }^{178}$ One can signal simply by reporting in a factual manner how one feels about the other individual. It is more effective, however, for an individual to resort to disparaging and insulting words or actions. Aristotle instructed that, to be effective, an insult must be gratuitous and must not otherwise accord with the insulter's self-interest. ${ }^{179}$ Refusing to engage in economic trades that would otherwise be mutually beneficial is, therefore, an effective way to disparage others. Because American society grants esteem partly on the basis of wealth, ${ }^{180}$ economic discrimination is doubly effective; it both disparages and inflicts economic loss on the other party.

176 The potential exists only when one expects to prevail in the status "war" that status production will bring about. If one shares traits with the majority or the economically and politically powerful, one can expect that subordination of the remainder will succeed. Attempting to produce status on the basis of traits shared by a minority may, however, prompt effective countersubordination.

177 There are also reasons external to the status-production model to expect continued overlap between shared-trait and socially connected groups. For example, at least in economies that lack a reliable legal infrastructure for enforcing contracts, socially connected minority ethnic groups may enjoy a comparative advantage in informal contract enforcement. See Sumner J. La Croix, Homogenous Middleman Groups: What Determines the Homogeneity?, 5 J.L. ECON. \& ORG. $2 \mathrm{II}$, 2I7-20 (1989); Janet T. Landa, $A$ Theory of the Ethnically Homogenous Middleman Group: An Institutional Alternative to Contract Law, 1o J. LEGAL STUD. 349, 359-62 (1981).

178 See Peggy C. Davis, Law as Microaggression, 98 YALE L.J. 1559, 1565-68 (1989); Patricia Williams, Spirit-Murdering the Messenger: The Discourse of Fingerpointing as the Law's Response to Racism, 42 U. MIAMI L. REV. 127, I29 (I987).

179 See Aristotle, Rhetoric II.2.1378b-79a (W.D. Ross ed. \& W. Rhys Roberts trans., 1924). The true snub occurs only when one goes out of one's way to ignore someone. Refusing to accept a gift is, other things being equal, more insulting than refusing to make a gift. Refusing to accept an invitation to do something one enjoys is more insulting than refusing to participate in an activity one does not enjoy. In each case, acting against one's own interests is both a less equivocal and a more intense signal of one's desire to insult.

180 See McAdams, supra note 59 , at 40 \& n.I58, 42 n.17o. 
Subordination will fail to raise one's status, however, if those one subordinates are able to respond in kind with equal force. The question arises, how does one "win" a competition for status if the competition is a mutual effort to manifest disrespect for each other? An important part of the game of subordination is to gain the approval of third-party observers - to induce them not to esteem the target of one's subordination. One obvious strategy, however, is to eliminate the existence of genuine third-parties by including them either in one's own group or in the group one is disparaging. Because a majority of opinion is, all else equal, better than a minority, this strategy often involves defining one's own group as the majority. ${ }^{181}$ There are many ways to categorize people according to their physical characteristics, which is why we see struggles over the definition of race. ${ }^{182}$ Status production explains not only the struggle, but also why it so frequently involves an attempt to define oneself as belonging to a majority group.

2. The Explanatory Power of the Status-Production Model. The status-production theory of discrimination is reductive in that it consciously omits some of the detail of racism and race discrimination. But even though the theory is not a complete account of the problem, it is a useful starting point for explaining race-related behavior and beliefs. ${ }^{183}$ The status-production theory explains considerably more aspects of race discrimination than the associational preference model. This section uses the theory to explain three categories of data: descriptions of the Jim Crow South; the contemporary relation between status and discriminatory attitudes; and the evolution of racial beliefs.

(a) Using Status Production to Explain the Jim Crow South. The initial virtue of the status-production model is its ability to explain discriminatory behavior in the Jim Crow South. Status production predicts both the separatist behavior the associational preference theory does explain and the behavior it does not explain. Consider again the evidence that whites engaged in, and coerced other whites to engage in, behavior that disparaged and insulted blacks. ${ }^{184}$ When sta-

181 Individuals do not, however, invariably prefer to be in the numerical majority. If a minority is high-status as a consequence of enjoying disproportionate political or economic power, or other badges of status, individuals may struggle to define themselves as belonging to that group instead of to the majority.

182 For group status production, there must be at least two groups, and thus, at least one boundary. Rigorously enforcing the boundary symbolizes the greater exclusivity of the dominant group. Thus race definitions that treat black ancestry as "tainting" an apparently white person contribute to the disparagement of blacks and the production of status for those defined as "truly" white.

183 Like Becker, I believe that the appropriate starting point for explaining discrimination is the paradigmatic case of overt racial animus. Although status production suggests that economists have misclassified some subtle racial animus as statistical discrimination, status production is only a starting point. It should be supplemented with other theories, including, where appropriate, the theory of statistical discrimination.

184 See pp. 1040-4I. 
tus production rather than aversion is the model, these behaviors are not only explicable; they are paradigmatic. By expressing disrespect and contempt toward a minority group, whites raise their relative status. Through allocation of intra-group status, whites induce other whites to produce inter-group status through acts of subordination.

Whites' reluctance to associate with blacks in some contexts but not in others is coherent given the consequences different forms of association have for status production. Some associations imply rough equality; others do not. Whites avoided associating with blacks in the former cases, but as long as the hierarchy was in their favor, not in the latter. Refusing to work alongside blacks in the symbolically equal rank of "co-worker," to sit next to or to use the same facilities as blacks, and to permit intermarriage were all effective means of disparaging and subordinating. 185

On the other hand, whites did not need to avoid associations that preserved the status hierarchy they desired. Some occupations, such as domestic servant, carry a social stigma; it is predictable that whites who abhorred other forms of association would employ blacks in such a capacity. Similarly, the sexual double standard in the Jim Crow South meant that extra-marital sexual relations had very different implications for men and women. White women known to have "lost their virtue" suffered public humiliation. Men, however, suffered no serious reputational loss and were assumed to enjoy the dominant role in any such relationship. Thus, it is not surprising that white men did not tolerate black men inflicting such a social disgrace on white women, while white men simultaneously enjoyed for themselves a wider sexual freedom and the attendant subordination of black women. We can now understand the particular emotional significance of sexual relationships between black men and white women: such illicit relationships were viewed as placing blacks in a dominant position over whites, while simultaneously depriving the women's white male relatives, suitors, or spouses of the status of their expected dominant position. ${ }^{186}$ In contrast to this racial double standard for extramarital sexual relations, even white men were prohibited from marrying black women because such a formal association would confer status on the black member of the couple. ${ }^{187}$

Further, recall that whites enforced various racial customs against other whites. It is no longer necessary to posit a uniquely powerful third-party preference to explain such behavior. A white individual's desire for status is a sufficient explanation, because the individual's

185 Moreover, for whites, occupying the subordinate position in a hierarchical relationship was a fate worse than equality. Having black elected officials was, therefore, anathema to discriminatory whites because it implied such a subordinate position.

186 See DoLLARD, supra note 125 , at 143-45.

187 See MYRDAL, supra note 124 , at 590. 
status "as a white" depends entirely on the behavior of other whites. Because subordination of blacks is a "public good" for whites, whites are keenly interested in the extent to which other group members contribute and are willing to punish those who interfere with production of this good. ${ }^{188}$ Thus, Jim Crow whites were predictably concerned about other whites who associated with blacks in a respectful manner that implied social equality. Dollard's sociological account of a southern town in the I930s was certainly not informed by contemporary game theory, but his observations clearly indicate the status punishment for what we now call a "free-rider":

A feature of white solidarity, as has been noted, is the harsh term that brands the caste traitor - 'nigger-lover.' Such a man enjoys the benefits of white solidarity, but does not stand by his caste. In the epithet there is an implication of inferiority and perhaps a threat of being classed with the scorned Negro. ${ }^{189}$

The effectiveness of status payments is demonstrated by the economic boycotts whites successfully employed against other whites who broke ranks ${ }^{190}$ or against blacks who threatened the existing order. ${ }^{191}$ Boycotting is a classic cartel behavior, usually made impossible by freeriding, but whites overcame their collective action problem and succeeded in inducing other whites to contribute to enforcing discriminatory status-producing norms. ${ }^{192}$

The status-production model also explains the high level of violence directed against blacks. Private violence could enforce subordinating customs that were either too complex or too patently offensive

188 The punishment takes the form of lowered intra-group status. "The white people enforce caste rules with ominous unanimity and one is compelled, by one's white-caste membership, to assist to some degree in the personal derogation of the Negro and the expression of hostile pressure against him." DoLLARD, supra note I25, at 349. Social ostracism was a powerful threat: "If one lives in Southerntown, 'not to be received' is a very serious matter and would be more so if one's family were there; living would be quite intolerable without opportunity for friendly contacts within the white caste." Id. at 354 .

189 Id. at 66 (emphasis added).

190 See RAPER, supra note I39, at 20. When a lynching occurred, "[t]he general public either justified or condoned the lynching, and any individual or group who disagreed was made to suffer. Merchants, bankers, lawyers, and preachers faced a public boycott - or thought they did - should they take a stand in defense of law and order." Id. Raper reported that a National Guardsman who used his bayonet to cut a white man who was attempting to remove a black rape suspect from custody "was never able after that time to keep employment in [that town]." Id. at 244 .

191 See Dollard, supra note I25, at I27.

192 The well-documented violence directed by whites against blacks is evidence that whites overcame the incentive to free-ride. After all, one incurs some cost by participating in a lynching, given the value of one's time and the risk of criminal ramifications which, while extremely low, were higher than zero. See RAPER, supra note 139, at 2, 32. The costs could be quite high if the

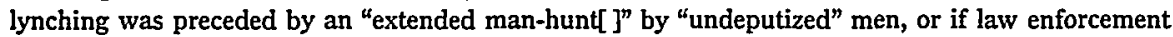
officials uncharacteristically resisted or threatened to resist a mob's attempt to remove a suspect from jail. Id. at I, 9-10, 14-15, 32, 244 . 
to be legislated. For example, it was difficult to state precisely in statutory language the tone of voice or the amount of eye contact a black person was permitted to use when addressing a white person, or other nuances that distinguished respectful from disrespectful behavior. But violence succeeded in enforcing a deferential demeanor. ${ }^{193}$ Similarly, violence prevented black economic progress, which whites were not willing or able to prohibit more directly. Southern whites engaged in a delicate hypocrisy. They passed laws that made it difficult for blacks to succeed economically, but white southerners' wish to believe that blacks' economic failure was their own doing probably prevented them from enacting laws that would facially deprive blacks of all prospect of economic success. Thus, when black successes threatened white status, whites used violence to defend their position and keep blacks in their place. ${ }^{194}$ Indeed, historians of the $\mathrm{Ku} \mathrm{Klux}$ Klan have described the organization as arising from the need of low-status whites to recapture a sense of social position. ${ }^{195}$

Finally, status production better explains the public choice aspects of Jim Crow segregation. Pecuniary selfishness sufficiently explains the rent-seeking goal of legislation to restrain competition from or for black labor. ${ }^{196}$ But material motives cannot explain how large white

193 See Dollard, supra note 125 , at $176-77$ ("[W]hite people become aggressive as soon as Negro submission is withheld, and many stories are told of the "what I did with that "uppity" nigger' type."); RAPER, supra note 139, at 48 ("The Negro must stay in his place' is a common phrase, and the white people who have defined 'his place' may be expected to react violently if they think he is either getting out of it or showing dissatisfaction with it.").

194 See MYRDAL, supra note 124, at 563. Myrdal reports:

Economic fear is mixed with social fear: a feeling that the Negro is "getting out of his place," and [that] the white man's social status is being threatened and is in need of defense. ... [T] [Tis feeling [underlies the] common saying ... that "a lynching now and then" is expedient or necessary in keeping the Negroes from becoming "uppity." . . [A]fter the First World War many lynchings of Negro soldiers - sometimes in uniform - were openly motivated by the fear that they had gotten "wrong ideas" about their social status while serving in France.

Id.; see also WALTER White, ROPE AND FAGGot II (I969) (suggesting that "lynching is much more an expression of southern fear of Negro progress than of Negro crime").

195 "While the Klan undoubtedly retained large numbers of middle-class supporters [in the rg20s] until its ultimate decline, the available evidence suggests that these were largely among the socially marginal and status-deprived elements in the stratum. . . . Its leaders spoke the language of the underdog Protestant." SEymour M. Lipset \& EARL RAAB, The Politics of UnReason I25 (1978). In the decade after Brown v. Board of Education, 347 U.S. 483 (1954), "the Klan tended to be less of a resistance than a status movement for some of those left insecure or unrecognized by society." David M. Chalmers, Hooded AMERICANISM 6 (1965). Racial violence also served to unite diverse white subgroups. See RAPER, supra note 139, at 47 ("Llynchings often serve as socializing forces ... [that] tend to minimize social and class distinctions between white plantation owners and white tenants, mill owners and textile workers, Methodists and Baptists .....).

196 "Enticement" laws, for example, restricted the ability of southern plantation owners to hire workers away from other plantations, see MYRDAL, supra note 124, at 248-49, and thus depressed the wages of blacks. See EPSTEIN, supra note II6, at 46, 246-49; Robert Cooter, Market Affirmative Action, 3I SAN Diego L. REv. 133, 139-4I (1994). 
groups overcame the collective action problem they faced in pursuing those ends. In particular, because the white laborers' interests were often at odds with the material ends of white capitalists, success was not assured merely because the legislature was all white. Intra-group status allocation, however, can explain how those competing socially connected white subgroups could each induce contributions toward the subgroup end to secure the desired legislation. Even when the end was material, status was still important as a means of accomplishing the objective. ${ }^{197}$

(b) Using Status Production to Explain Who Discriminates. The associational preference model has little to say about why some people discriminate more than others, except for the circular claim that some people have stronger discriminatory tastes than others. ${ }^{198}$ The status-production model offers a deeper explanation of these differences.

First, the status-production model explains why whites in the Jim Crow South were more intensely discriminatory than whites in other parts of the United States. One is tempted to make some claim about the relevance of slavery; surely it is not a coincidence that the region that maintained black slavery the longest was the most hostile to blacks. But the associational model would suggest just the wrong relationship: where slavery was common, "contact" with blacks was more common, ${ }^{199}$ so that the absence of slavery in the North would seem to imply that northern whites had a stronger preference for avoiding contact than southern whites. ${ }^{200}$

The status-production model explains the relationship between geography and discriminatory behavior in the hundred or so years after the Civil War. First, southern whites had a lower social status than northern whites. Southerners had lost a war, had had emancipation forced upon them, and had suffered economic devastation and armed occupation. Thus, for many southern whites, discrimination represented a scarce means of reclaiming lost status. ${ }^{201}$ In addition, newly freed slaves in the South had lower social status than free blacks in

197 Nor does rent-seeking explain why race, as opposed to any other means of grouping, was the axis along which individuals chose to organize. The status-production theory, however, explains why there is frequent overlap between shared-trait groups, like races, and the socially connected groups that are capable of inducing their members to contribute to lobbying activities. See supra notes $175-176$ and accompanying text.

198 See BECKER, supra note 114, at 17 , 2I, I56.

199 See WOODWARD, supra note 124 , at 13.

200 An associational preference proponent might respond that slavery was more prevalent in the South because it was a more productive means of agriculture for southern than for northern farmers. Yet southern whites seemed to permit more association than siavery required, at least for house servants and in urban areas. See, e.g., id. at I2-I6. Moreover, even if agricultural economics explains why slavery predominated in the South, it cannot explain why southerners were more discriminatory than northerners.

201 See DoLlarD, supra note 125 , at 50-5I, I86. 
the North. Slavery had so degraded blacks that equal relations between former slaves and whites had a greater potential to lower the status of whites than relations between whites and any other group including blacks - in the North. Thus, after Reconstruction, southern whites employed segregation to counter the threat that black economic progress $^{202}$ and a new generation of less deferential blacks ${ }^{203}$ posed to white status. Perhaps most important, the larger population of blacks in the South ${ }^{204}$ made their upward mobility a greater threat to white status than it was in the North; stated conversely, the larger black population meant that racial subordination was more productive of status for southern than for northern whites. ${ }^{205}$

The status-production model also explains the shape of contemporary attitudes on race. For instance, among whites, there is a strong inverse relationship between social status and discriminatory racial attitudes. $^{206}$ The poorest and least educated whites, for example, were

202 See WhITE, supra note I94, at II.

203 See, e.g., Charles A. Lofgren, The Plessy CASe 25 (I987) ("[T] the initial wave of Jim Crow legislation was increasing black unwillingness to defer to whites.").

204 See Michael J. Klarman, Brown, Racial Change, and the Civil Rights Movement, 80 VA. L. REv. 7, 30 (1994) ("At the beginning of the twentieth century, over 90\% of American blacks lived in the eleven former Confederate states .....

205 The smaller the upwardly mobile group, the less their success will push other groups down in relative terms; indeed, effectively subordinating a larger group necessarily places one higher in social rank than subordinating a smaller one. The status-production theory thus explains why, within southern counties, severity of discrimination was positively correlated with black population. See id. at 68. A larger group, however, is more difficult to subordinate than a smaller one; absent disproportionate economic or political power by the majority, we might expect that as the size of the minority population approaches a majority, subordination will level off or decline. In the Jim Crow South, however, whites enjoyed such disproportionate power that they could effectively subordinate a black majority, and the above correlation still held in such cases. See id.

Becker's theory also fails to explain why segregation appeared to be so one-sided, imposed by whites on blacks. See MYrDal, supra note 124, at 575-77. Whites appeared to have had a stronger aversion to interracial contact than blacks. Violence may have deterred blacks from expressing their desire to avoid association with whites. But in the associational model, because the only purpose of violence is to deter association, the one-sidedness of violence suggests that blacks wanted association more than whites. The status-production model offers an explanation: given the stark status hierarchy, whites stood to lose social status by associating in equal relationships with blacks, while blacks did not. This explanation is consistent with the call by some black intellectuals at the time for separatism. See, e.g., Robert S. Browne Urges "A Formal Partitioning of the United States Into Two Totally Separate and Independent Nations," in BLACK Protest Thought IN The Twentieth Century 516, 526-28 (August Meier, Elliott Rudwick \& Francis L. Broderick eds., 2 d ed. 1971). Segregation loses some of its stigma when the minority chooses to separate rather than having the majority choose to exclude. Moreover, if one can form sufficiently intense feelings about group members, it is possible one will no longer care about the esteem granted or withheld by non-members. Cf. Julius Lester, The Angry Children of Malcom $X$, in Black Protest Thought IN the Twentieth Century, supra, at 469, 483 ("[The white man] is not to be lived with and he is not to be destroyed. He is simply to be ignored . . . .").

206 See, e.g., Donald L. Noel \& Alphonso Pinkney, Correlates of Prejudice: Some Racial Differences and Similarities, 69 AM. J. Soc. 609, 611-12 (1964); Thomas J. Pavlak, Social Class, Ethnicity, and Racial Prejudice, 37 PuB. OpInIon Q. 225, 229-30 (1973); A. Wade Smith, Racial Tolerance as a Function of Group Position, $4^{6}$ AM. Soc. REv. 558, 563-6y (1981). 
the most likely to participate in lynching blacks. ${ }^{207}$ Sociologist Judith Caditz summarizes: "For decades social scientists have tried to understand reasons people affirm prejudicial attitudes and engage in discriminatory behavior. Much social science literature supports the thesis that status-threatened people will exhibit prejudicial attitudes toward minorities."208 Caditz adds that those who think their membership in ethnic, religious, occupational, and other social groups or classes is important are more likely to hold ambivalent or negative attitudes about blacks. ${ }^{209}$ These findings are the most direct contemporary evidence supporting the status-production model. Whites with the most limited opportunities for producing status will predictably be prepared to engage in more discrimination, because lowering the status of others is one of their last remaining mechanisms of status production. ${ }^{210}$ Similarly, the more closely one identifies with one's racial or ethnic group - that is, the more one's status depends on the status of racial traits, the more one can produce status by subordinating (or being willing to subordinate) others on racial grounds.

The literature on racial attitudes and status is not without conflict. Some research suggests that status mobility is a better predictor of racial attitudes than status position and finds that those who have experienced significant change in status have more negative racial attitudes than those whose status is relatively stable. ${ }^{211}$ In particular, newly ar-

207 See RAPER, supra note I39, at 6, IO-II.

208 Judith Caditz, White Liberals in Transition 9I (1976). A review of psychology literature reveals a similar finding: "the more negative the self-attitudes, the greater the number of unacceptable targets and the more negative are attitudes toward them." HowARD J. EHRLICH, The Social Psychology of Prejudice i63 (1973); see also John E. Farley, Majority-MiNORITY RELATIONS 26 (2d ed. I988) ("Persons in lower [socioeconomic status] groups tend to report more negative views toward out-groups, to be more ethnocentric, and to express more

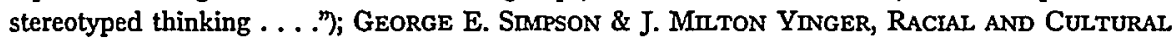
Minorities: AN ANALYsis of PREJUdice aNd Discrimination 66-70 (5th ed. ig85) (finding "strong evidence[ for class differentials in prejudice").

209 See CadrTz, supra note 208, at 100-or. For example Caditz found that "[t]hose affirming the importance of their ethnic group exhibit more dilemmas toward busing, apartment rentals to blacks, and hiring blacks than the comparison group." Id. at Ior.

210 Individuals can obtain status by achievement or talent - for example, displaying wealth is a common means of gaining esteem. See McAdams, supra note 59, at 38-44. Those who have neither wealth nor some other positive accomplishment as a basis for esteem are the most likely to seek esteem in other ways, such as subordination.

211 Caditz's research supports this finding. She queried white "liberals" about race:

In general, the more stable and status secure, the more likely white liberals will affirm favorable attitudes toward interracial social situations. Conversely, the more status insecure, the more status threatened white liberals will feel, and consequently, the more likely they will be to reveal attitudes unfavorable toward interracial situations.

CADITz, supra note 208, at 107. Yet Caditz found "no significant differences between groups compared on the basis of their actual ranks in occupation and in education." Id. at ro4. She concludes that "mobility per se, irrespective of the actual ranks, is associated with the degree of favorableness toward ... interracial situations." Id.; see also BRUNo BETTELHEIM \& MORRIS JanOwITZ, Dynamics OF PREJUdICE 150-5I (1950) (finding the greatest prejudice against blacks among the downwardly mobile, followed by the non-mobile, then the upwardly mobile); Joseph 
rived immigrants unable to speak the dominant language have often lost whatever status they enjoyed in their homeland, while their reason for having left is often to gain a higher status than was possible in their homeland. During this time of high status mobility, many immigrants engage in high levels of discrimination. ${ }^{212}$ Status competition explains the tension that often exists between different minority groups as each new group seeks to establish its place in the social hierarchy. ${ }^{213}$ The exact relationship is part of an ongoing social science debate. Without seeking to resolve that debate here, I note only that the associational preference model offers no hope of explaining such patterns.

(c) Using Status Production to Explain Racial Beliefs. - There is considerable evidence that, since the I950s, white attitudes have shifted enormously toward greater tolerance of African Americans. Whites have shown a greater willingness to accept the principle of equal opportunity and less willingness to express negative statements about blacks. ${ }^{214}$ Yet there is also significant evidence that race continues to matter. Whites still appear to discriminate racially in politics, ${ }^{215}$ and whites and blacks differ considerably in their views regarding the

Greenblum \& Leonard I. Pearlin, Vertical Mobility and Prejudice: A Socio-Psychological Analysis, in Class, Status aNd Power 480, 49I (Reinhard Bendix \& Seymour M. Lipset eds., 1953) (finding more ethnic prejudice among upwardly and downwardly mobile than among non-mobile persons).

212 See MYRDAL, supra note I24, at 603 ("[T]he development of prejudice against Negroes [was] usually one of [the] first lessons in Americanization for [new immigrants residing in the North]. Because they are of low status, they like to have a group like the Negroes to which they can be superior."); see also RoEDIGER, supra note $16_{3}$, at $\mathrm{I33}^{-63}$ (discussing the history of IrishAmerican racial consciousness).

213 See CADITZ, supra note 208, at 118 (discussing conflict between blacks and Mexican Americans); ROEDIGER, supra note 163 , at ${ }^{2} 33-63$ (discussing conflict between blacks and Irish immigrants).

214 Professor Bobo reports:

In I942, approximately $60 \%$ of whites believed that blacks were less intelligent than whites. By 1964, that figure had declined to less than $25 \%$. A substantial majority of white Americans in 1942 approved of the blatantly discriminatory proposition that "white people should have the first chance at any kind of job," whereas in 1972 nearly $100 \%$ of whites in a national survey rejected that statement.

Bobo, supra note r6o, at 88 (citations omitted). See generally Howard Schuman, Chardotte STEEH \& LAWRENCE Bobo, RACIAL ATTITUDES IN AMERICA $7 \mathrm{I}-\mathrm{I} 38$ (1985) (discussing trends in white racial attitudes between 1942 and 1983 ). Even if survey subjects are concealing their "real" views, the survey results suggest that something has changed, if only the willingness to admit to anti-black or anti-integrationist views.

215 Whites remain reluctant to vote for black politicians. Cf. Donald R. Kinder \& David $\mathrm{O}$. Sears, Prejudice and Politics: Symbolic Racism Versus Racial Threats to the Good Life, $40 \mathrm{~J}$. PersonaltTy \& Soc. PSYCHOL. 414, 427-30 (198I) (analyzing white voters' racial attitudes and preferences); John B. McConahay \& Joseph C. Hough, Jr., Symbolic Racism, 32 J. Soc. Issues 23, 36-44 (1976) (analyzing voter preferences in terms of "symbolic racism"). That reluctance increases when blacks are a large percentage of the population. See Schuman, SteEH \& Bono, supra note 214 , at 204. Regarding economic discrimination, see notes 239 and 258 below. 
appropriate measures for achieving equality and integration. ${ }^{216}$ This section uses status production to speculate on the causes of this limited evolution. The analysis proceeds in two steps. First, I describe a static theory of racial beliefs, arguing that status production explains how biased racial belief formation or "ideology" can persist despite its instrumental costs. Second, I venture a dynamic theory to account for the evolution of those beliefs, claiming that ideology is essential for status production to succeed and that dramatic shifts in attitudes occur when external events strip status-seeking of its ideological cover.

The desire for status can systematically distort beliefs. The conventional assumption is that false beliefs are costly because mistakes impede the individual's effort to satisfy her preferences. This approach mistakenly assumes that beliefs are useful only as a means of determining what behavior will serve one's interests. To the contrary, casual observation confirms that people derive pleasure from merely expressing their beliefs. Indeed, the act of voting is expressive, and many rational choice theorists have abandoned any attempt to explain political voting except as an expressive activity enjoyable in and of itself. $^{217}$

Once we understand that people gain utility from expressing their beliefs, we can identify a category of beliefs not subject to the usual economic constraints. We can now imagine, for example, why people bother to form beliefs about so many things that do not seem instrumentally important, such as who is the best goalie in professional hockey, whether a celebrity is guilty or innocent of criminal charges, or which of two films is better. People form such beliefs for the plea-

216 See Schuman, Steen \& Boвo, supra note 214, at I54-62 (discussing disparity between black support for principles of integration and implementation of such principles); Bobo, supra note I60, at 88-89; Thomas F. Pettigrew, Racial Change and Social Policy, 44I ANnals Am. ACAD. POL. \& Soc. SCI. II4, IIg (I979) ("[W]hite Americans increasingly reject racial injustice in principle but are reluctant to accept the measures necessary to eliminate the injustice."). Of course, white opposition may arise out of commitment to libertarian principles or beliefs about the cost and benefits of such proposals. But the question remains why whites and blacks hold such different views on these matters. See Schuman, SteEH \& Bobo, supra note 2I4, at I39-62; Lawrence Bobo, Attitudes Toward the Black Political Movement: Trends, Meaning, and Effects on Racial Policy Preferences, 5I Soc. Psychol. Q. 287, 299-300 (rg88).

217 Many have argued that voting is not instrumentally rational. One ballot can affect the outcome of an election only if the vote would otherwise be tied. Thus, the odds against one vote's affecting the outcome of a modern American election are so great that the cost of voting (even the very low risk of dying on the way to the ballot box or the five minutes it takes to vote) apparently outweighs by a wide margin any expected instrumental benefit. See, e.g., DanIEL A. Farber \& Philip P. Frickey, LaW and Public Choice 24-27 (1991). Voting is rational, however, if understood as an expressive end in itself. The utility derived from voting "is related to the utility that people derive from speaking their mind about some subject, even though nothing will be changed thereby." Richard A. Posner, What Do Judges and Justices Maximize? (The Same Thing Everybody Else Does), 3 SuP. CT. ECON. ReV. I, I9 (1993); see also Geoffrey Brennan \& Loren Lomasky, The Impartial Spectator Goes to Washington: Toward a Smithian Theory of Electoral Behavior, I EcoN. \& PHI. I89, I99 (I985) (arguing that voting is "a potentially valued avenue for the expression of moral sentiments"). 
sure that comes from expressing them. The novelty of these otherwise non-instrumental beliefs is that the normal economic correctives to false belief formation do not apply. For expressive purposes, a "good" belief is not necessarily an accurate belief, but rather one that is pleasurable to express. Of course, even if a category of beliefs serves only expressive ends, there are some constraints on belief formation. Our cognitive mechanisms may make it difficult for us to believe certain things that are manifestly contradicted by experience. Moreover, we may not experience the full pleasure of expressing our beliefs if others find them palpably false in an uninteresting way. ${ }^{218}$

Most important for our purposes, however, is the constraint of selfesteem. Some beliefs are more pleasant than others. For expressive purposes, people are more likely to adopt beliefs that enhance, rather than degrade, their self-esteem. If the issue is the talent of a celebrity, for example, a person is more likely to think highly of the celebrity if, through some connection - having attended the same school, for example - the celebrity's talent will enhance the individual's self-esteem. If esteem can influence expressive belief formation in this manner, esteem can also affect conventionally instrumental beliefs beliefs concerning how best to satisfy one's preferences. As long as the gain in esteem from the bias toward esteem-producing beliefs is larger than any instrumental loss from the bias, then such a bias serves the individual's overall interests. There is considerable evidence to support this claim: research shows, for example, that people tend systematically to overevaluate their own performance and characteristics. ${ }^{219}$ Such a bias may even be essential to mental well-being. ${ }^{220}$ Self-evaluation is clearly an instrumental belief - one needs to know what one's talents and abilities are - yet the need for self-esteem is sufficient to create some deviation from strictly impartial beliefs about oneself.

If esteem production favorably biases one's self-evaluations, esteem production may also cause a positive bias toward the social groups to which one belongs. 221 One may gain pleasure from believing positive things about one's groups. Moreover, groups will reward status to

218 Supermarket tabloids and talk radio often thrive on the expression of palpably false beliefs, apparently because they are false in an interesting way.

219 See Hazel Markus, The Self in Thought and Memory, in The Self in Social PsycrolOGY I02, 125 (Daniel M. Wegner \& Robin R. Vallacher eds., r980); Shelley E. Taylor \& Jonathon D. Brown, Illusion and Well-Being: A Social Psychological Perspective on Mental Health, I03 Psychol. BULL. I93, I97 (1988) (" $[\mathrm{A}]$ great deal of research in social, personality, clinical, and developmental psychology documents that normal individuals possess unrealistically positive views of themselves .....").

220 See Taylor \& Brown, supra note 219, at 197; Howard Tennen \& Sharon Herzberger, Depression, Self-Esteem, and the Absence of Self-Protective Attributional Biases, 52 J. PERSONALITY \& Soc. PsYCHOL. 72, 72 (1987).

221 See Tajfel \& Turner, supra note 34, at 7; cf. Taylor \& Brown, supra note 219, at 195 (stating that "individuals [tend] to see their intimates as better than average"); Alvin Zander \& 
those who hold beliefs that are conducive to group welfare. A favorable bias regarding group members may strengthen intra-group cooperation by increasing the apparent material advantage available from transacting with members rather than non-members.

But groups may encourage and reward beliefs more complex than simple bias. For example, although he does not explain how belief distortion occurs, Richard Posner has invoked such distortion to explain how certain cartels solve collective action problems. ${ }^{222}$ According to Posner, the distinguishing feature of certain successful cartels which he terms "guilds" - is their having an "ideology."223 A guild is a social as well as an economic institution in which members have adopted a common "personal morality" of loyalty, conformity, and craftsmanship, and which has achieved a certain "mystique" involving the idealization of quality over quantity.224 The "mutually reinforcing combination" of this morality and mystique comprises "the ideology of guild production," which serves the "the self-interest of producers in the cartelization of production."225

Posner appears to mean that guild members convince themselves that the public interest is served by the restrictions on market entry and production necessary to cartelize an industry. This analysis implies that a principled concern for the public good has some force in motivating behavior, so that cartel members would be even more likely to free-ride if they realized that cartel pricing is contrary to the public interest. Ideology, however, turns the moral force against freeriding. An ideological commitment to quality allows the guild member to believe that conduct that would undermine the cartel - lowering quality and expanding output - would harm the public. ${ }^{226}$ Self-inter-

Warwick Armstrong, Working for Group Pride in a Slipper Factory, 2 J. APPLIED Soc. PSYchol. 293, 304 (1972) (discussing how interest in team pride affects beliefs about the team).

222 See Richard A. Posner, The Material Basis of Jurisprudence, 69 IND. L.J. I, 10 (1993); see also EisTER, supra note II, at 37-38 (describing "wishful thinking," a process by which individuals form beliefs they previously wished to be true). See generally Thomas GILovich, How WE KNow What IsN'T So: The FallibIIITy of Human Reason IN Everyday LIFE 75-87 (I99I) (discussing how desire leads to self-serving beliefs); David PEARS, Motivated IrRationality 4 $\mathrm{x}-66$ ( $\mathrm{rg} 84$ ) (discussing explanations for self-deception).

223 See Posner, supra note 222, at II-I2.

224 See id. at II. "[A]n aid to, and perhaps even a condition of, successful cartelization is the creation of an ideological rather than a purely contractual community." Id. at 20 .

225 Id. at Ir. Posner compares the characteristics of medieval guilds to the modern legal profession. He argues that lawyers have used guild-like strategies to cartelize the supply of legal services and that a certain part of what passes as "jurisprudence" is this profession's self-serving ideology. See id. at $\mathrm{I}-3$.

226 See id. at 8. ("We are therefore not surprised that the charter of the weavers' guild recites that monopoly is necessary to protect the public from deceptively cheap - because shoddy, but difficult to recognize as such - merchandise sold by foreigners and other undependable people."). Posner traces how the "quality-protection rationale (or rationalization) for prohibiting entry" evolved into the basis for all guild life, particularly for a restricted output through a "vigorously propagated ... norm of craftsmanship." Id. at 8-9. Absent this moral restraint, enforced by 
ested self-deception thus serves the cartel's long run interests by curbing the individual's impulse to free-ride on the restraint of others.

Return now to racial beliefs. In Posner's terms, negative stereotypes are part of a racial "guild's" efforts to monopolize production of esteem. Even for beliefs that serve an instrumental purpose (such as evaluating potential employees), the desire for esteem will cause an individual to adopt distorted beliefs about racial groups as long as the esteem benefit exceeds the instrumental cost. Consequently, the statusproduction model can explain differences in voting behavior between blacks and whites. A person may gain esteem by believing positive things about political candidates from her own group and, at least in a relative sense, negative things about politicians of other races. If people do not vote for instrumental reasons, there is no instrumental check on the accuracy of these beliefs. A small bias may suffice to explain a significant difference in voting behavior because, for different racial groups, the bias works in opposite directions. ${ }^{227}$

If one assumes that this analysis correctly explains the existence and direction of racial bias, the question remains how to explain the evolution of white attitudes regarding race. Recall that status production commonly involves the denial that one's motive is status production. ${ }^{228}$ When one seeks to gain status by lowering the status of others, it is all the more important to deny that one is degrading others in order to look better by comparison. Consequently, "guild ideology" never acknowledges its self-serving nature. Members of Posner's representative guild do not openly declare, even among themselves, that they desire to restrain competition in order to charge higher prices and earn monopoly profits. Similarly, whites never explain their discriminatory behavior as serving the function of status production. Even in the Jim Crow South, whites attempted to justify segregation not by reference to naked self-interest but by claims that blacks were inherently inferior, that blacks preferred segregation, or

informal sanctions within a socially cohesive body, individual guild members would seek greater profits by expanding output, thus depriving the guild of its monopoly power. See id. at 8, 10.

227 Thus, if voting has only expressive benefits, whites must believe, more often than blacks, that policies that help blacks are bad ideas and that black candidates will do a poor job. Indeed, many studies have found that self-interest does not explain white opposition to black candidates or other race-related voting. Personal vulnerability on an issue does not successfully predict attitudes or voting behavior concerning those issues. See James R. Kluegel \& Eliot R. Smith, Affirmative Action Attitudes: Effects of Self-Interest, Racial Affect, and Stratification Beliefs on Whites' Viewes, 61 SOC. FoRCES 797, 813 (1983); David O. Sears \& Harris M. Allen, Jr., The Trajectory of Local Desegregation Controversies and Whites' Opposition to Busing, in GroupS IN CoNTACT: The Psychology of Desegregation 123, 128-29 (Norman Miller \& Marilynn B. Brewer eds., 1984).

228 See supro note Iro and accompanying text. 
that segregation somehow reflected the natural order of things. ${ }^{229}$ Toward this end, the Jim Crow doctrine of "separate but equal" was ideal. Separation was a means of expressing contempt; the pretense of equality served to deny the status motivation. ${ }^{230}$

When proponents of a status-driven ideology can no longer confidently deny the status motivation of their beliefs, the ideology fails and proponents must search for another ideology. This insight may explain the evolution of white attitudes toward segregation. Although the exact causal strands are difficult to disentangle, events leading up to and including the modern civil rights movement undermined the ability of whites to believe that their existing racial beliefs were anything other than a self-serving ideology. World War III provided one ideological shock, as revulsion to Nazi claims of racial superiority was difficult to square with rationalization of southern racial practices. ${ }^{231}$ Rising levels of black education and job skills put a material strain on racial ideology by raising the attractiveness of black labor and thus the cost of absolute racial exclusion. ${ }^{232}$ I suspect the most immediate cause of ideological breakdown occurred during the civil rights movement, when photographs captured segregation extremists using violent

229 Myrdal observes:

It would, indeed, be possible to defend the caste order simply by arguing that it is in the white people's interests to keep the Negroes subordinate. Such a defense would be logically tight. ... Unlike the rationalizations [that Negroes like to be separated or that separation is necessary to prevent social friction], it need not look forward to an ultimate social equality as ideal. ... .

The remarkable thing, however, is that, in America, social segregation and discrimination will practically never be motivated in this straightfonward way as being in white people's interests. Indeed, to judge from the discussion in all social classes of whites, and this is particularly true of the South, one is led to believe that such base and materialistic considerations never enter into their thoughts.

MYRDAL, supra note I24, at 585. Religion and science provided ideological rationalizations for slavery and then segregation. See Stephen J. Gould, The Mismeasure of MAN 42-43 (I98I); RAPER, supra note I39, at I9 (stating that lynchers and lynching apologists "assume that the Negro is irredeemably inferior by reason of his race - that it is a plan of God that the Negro and his children shall forever be "hewers of wood and drawers of water"'). Indeed, that southern segregationists seemed to believe their charge "that the civil rights movement was communistinspired" refiected an unwillingness to accept that local blacks opposed Jim Crow segregation. Klarman, supra note 204, at 81; see also NeIL R. MCMILLEN, The CitIZENs' CouncIL 207 (Illini Books I994) (I97I) ("In the folklore of the Deep South there is no more cherished fiction than that of Negro contentment with segregation.").

230 In fact, the pretense of equality served to enhance the production of status because whites could then (choose to selfishly) believe that the failures of blacks to achieve equality were their own fault. In a sense, whites could gain the benefit of cheating in a competition without the loss of self-respect that comes from acknowledging that one is cheating.

231 See Klarman, supra note 204, at 23-26.

232 See id. at 20-2I (describing how World War II labor shortages increased black employment in skilled positions); $i d$. at 52-65 (reporting that urbanization and industrialization increased demand for black labor and that industrial jobs created a black middle class less vulnerable to white control); $i d$. at $65-67$ (detailing increased education levels). In other words, discriminatory norms may be stable given fixed economic conditions but may change if new conditions make transacting with blacks more materially beneficial. 
means, often against women and children, to suppress peaceful protests. Violence against peaceful demonstrators was, even for some southern supporters of Jim Crow, irrefutable evidence that whites were not (at least morally) superior, that blacks were indisputably unhappy with segregation, and that segregation was not a naturally ordained moral order. ${ }^{233}$ One of the constraints $I$ have suggested for non-instrumental beliefs is "palpable falsity"; the events of the r950s and rg6os made salient to whites the falsity of the belief that intentional racial segregation is something other than selfishly hurtful.

Whatever the causal mechanism, many whites have come genuinely to believe that segregation is wrong. This shift does not mean, however, that a psychological veil of prejudice has simply been lifted from their eyes. The expressive beliefs whites adopt about race can no longer be of the crude form needed to justify segregation, but the quest for the production of status continues. Having abandoned the older ideology, whites still tend to oppose policies and candidates that would increase the social status of blacks. ${ }^{234}$ Whites can give up old, extreme stereotypes and still embrace negative views of blacks. Unless one consciously scrutinizes the statistical validity of one's generalizations about other groups - an unlikely scenario - even false stereotypes will rarely be palpably false. Thus, one may acknowledge the good faith and intellectual integrity of conservative arguments on political issues concerning race - like busing, affirmative action, and welfare - and still worry that the same status-maximizing bias that first rationalized slavery and then segregation infects much of the public thinking on these matters. It is more pleasant to believe that one lives in a society in which everyone (or at least everyone else) is being treated as well as she deserves, that past transgressions have been righted, and that fairness and justice require no further sacrifice. The evolution of white attitudes, therefore, reflects an ideological adjustment to status production under changed circumstances. The final descriptive virtue of the status-production theory is that it offers some insight into this otherwise puzzling evolution of white attitudes. ${ }^{235}$

233 The immediate effect was to convince many northern whites that segregation was suffciently immoral to merit national legislation. See id. at I45-49. As to southern whites, I speculate that the same force contributed to long term attitude changes.

234 See supra notes $215-216$.

235 The model also provides a useful beginning for economic analysis of sexism. Like racial features, one's sex is reasonably observable. Men, like whites, often belong to exclusive socially connected groups. Racism and sexism each allow the oppressor to "feel superior; thus, a 'poor white' in the South can console himself with the thought that he is not a 'dirty nigger' . . . . [T]he most mediocre of males feels himself a demigod as compared with women." SIMONE DE Beauvorr, The Second Sex at xxiv (H.M. Parshley ed. \& trans., Alfred A. Kropf r953) (1949). As Beauvoir notes, however, there are important differences between sexism and racism. See id. at xviii. Within the status theory, the most important distinction is the extent to which men and women depend on each other for their social status. Men typically belong to socially connected groups, such as families, that contain women. Given such relationships, a man who disparages 


\section{Implications of the Status Production Model of Discrimination}

The associational model of discrimination has two key implications: market competition will erode discrimination and, partly for that reason, prohibiting race discrimination is inefficient. ${ }^{236}$ The status-production model leads to different conclusions on both points.

r. The Persistence of Race Discrimination. - Becker drew an analogy between race discrimination and transportation costs, both of which increase the cost of certain trades. ${ }^{237}$ It is uncontroversial that, other things being equal, those who can minimize transportation costs achieve a competitive advantage over those who cannot. If the analogy with discrimination is sound, we should also expect that whites with less intense tastes for discrimination will enjoy a competitive advantage over those with more intense tastes and will tend to dominate a competitive market. ${ }^{238}$

Under the status-production model, discrimination is not the result of costs that discriminators incur from contact with members of other groups, but is a means of producing status. The discriminator does bear a cost in discriminating - forgoing otherwise beneficial trade with the objects of the discrimination - but that cost is an investment in the production of status. As long as such investments are cost-effective for the discriminator, the status-production model predicts that race discrimination will persist in the face of market competition. ${ }^{239}$

women would seem to threaten his own status. The male's response to this problem is twofold. First, he claims the dominant position within the family relationship. Second, he seeks a means of distinguishing the females with whom he associates from the rest of the females of the world. Of course, status is obtained from other men in this manner only if it derives from some male consensus as to what constitutes desirable female behavior or attributes. Consequently, social norms arise within socially connected groups of men that define a standard of female behavior. Men then gain status by being associated with women who follow these roles well. Thus, men subordinate a group that includes family members by employing a rich ideology of gender roles that allows them to distinguish between their female relatives and other women - between "good" and "bad" women.

Another key distinction between racism and sexism is that, unlike blacks, women are not in the minority. Successful subordination often requires a majority, since an equally large class of victims may respond with equally effective counter-subordination. But even a non-majority group with disproportionate material and political power can still succeed in subordinating others. That men succeed in setting the terms for esteem seems to depend upon them having economic superiority - a fact that must first exist for reasons status production does not explain. For an interesting game theory explanation, see Carol M. Rose, Women and Property: Gaining and Losing Ground, 78 VA. L. REV. 42I, 429-54 (I992).

236 But see Donohue, Title VII, supra note 120, at 1412; Donohue, Prohibiting Sex Discrimination, supra note 120 , at $1347-48$.

237 See BECKER, supra note II4, at I9-2I \& n.3, 32-38.

238 See id. at $43-45$ (" $[1] f$ the production function of each firm were linear and homogeneous, [market discrimination] would equal zero if at least one employer had . . . zero [taste for discrimination]."); POSNER, supra note 3 , at 65 I.

239 There is significant evidence of persistent discrimination in competitive markets. See, e.g., Alicia H. Munnell, Lynn E. Browne, James McEneaney \& Geoffrey M.B. Tooteli, 
Consequently, the transportation analogy is inapt. Discrimination may exist in a competitive equilibrium for at least three reasons: the power of discriminatory social norms; the existence of reciprocity between whites; and, under certain circumstances, the effect of esteem-producing racial biases. I will examine each of these in turn.

(a) The Stability of Discriminatory Norms. - This section presents a theory of discriminatory social norms. I begin with George Akerlof's economic theory of a racial caste system. I then raise and respond to two key objections to Akerlof's theory - that it does not explain why anyone enforces the caste-based norms, and that it does not capture the complexities of modern American society. I conclude that, despite market competition, status production can support a stable system of discriminatory norms.

Akerlof has provided an explanation for the resiliency of the discriminatory customs of a caste society. ${ }^{240}$ It is the essence of a castesystem, Akerlof says, that "any transaction that breaks the caste taboos changes the subsequent behavior of uninvolved parties" who may act to punish the caste-breaker. ${ }^{241}$ Third party reactions change the calculus for those who have not internalized the norm:

Those who fail to follow, or even to enforce the caste customs do not gain the profits of the successful arbitrageur but instead suffer the stigma of the outcaste. If the punishment of becoming an outcaste is predicted to be sufficiently severe, the system of caste is held in equilibrium irrespective of individual tastes, by economic incentives; the predictions of the caste system become a self-fulfilling prophecy. ${ }^{242}$

MORTGage Lending IN Boston: InTERpReting HMDA Data 2 (Federal Reserve Bank of Boston Working Paper No. 92-7, 1992) (finding that black mortgage applications in the Boston area were turned down $60 \%$ more often than applications from similarly situated whites); MARGERY A. Turner, Michael. Fix \& Raymond J. Struyk, Opportunities Denied, Opportunities Di. MINISHED: RACIAL DISCRIMINATION IN HIRING 37-59 (1991) (reporting Urban Institute studies that found employment discrimination); Ian Ayres, Further Evidence of Discrimination in New Car Negotiations and Estimates of Its Cause 12-16 (1994) (unpublished manuscript, on file at the Harvard Law School Library) (finding that car dealers offered worse deals to black than to white test purchasers). Some commentators reject such studies on methodological grounds. See, e.g., EPSTEIN, supra note II6, at 5I-58 (critiquing the Urban Institute and Ayres studies). I merely note that the intensity of one's methodological skepticism depends greatly on whether one believes that discrimination, in theory, can exist in competitive markets. If this section succeeds in demonstrating that it can; there will be less reason to doubt such studies. And to the extent that the methodologies are sound, the studies suggest the importance of the mechanisms I describe.

240 See AKERLOF, supra note 83, at 35 (contrasting existing analysis, which assumes that "current transactions (so long as they are legal) do not result in changed relations with uninvolved parties in subsequent transactions"); see also id. at $71-72$ (arguing for a model of custom-preserving equilibrium).

241 Id. at 35 .

242 Id. at 36 . Akerlof develops a formal model of caste equilibrium that applies to race discrimination. See id. at $37-4 \mathrm{r}$. 
Thus, Akerlof applies to race discrimination the same view of social norm enforcement that Ellickson has applied to property law - because people boycott norm breakers, it often pays to follow norms. ${ }^{243}$

This insight would be trivial, however, if it only applied when everyone in society was willing to boycott those who break the caste rules. Surely a few individuals will always be willing to deal with social outcasts (such as other social outcasts or near outcasts). One could argue that, as long as the number of people willing to violate the discriminatory norms exceeds the number of people targeted by the norm, violators need suffer no harm. ${ }^{244}$ Further, one might predict that if a few people violate the norm intially, their violation will weaken the norm and induce other violations to follow, eventually leading to the norm's complete unraveling. ${ }^{245}$

243 According to Richard A. Epstein, The Status-Production Sideshow: Why the Antidiscrimination Laws Are Still a Mistake, 108 HARV. L. Rev. 1085, I100-04 (1995), the history of Jim Crow demonstrates that discriminatory social norms require the support of violence. As he puts it, "[c]oercion is always the main event; status production is the side show." Id. at rog2.

There are two problems with this analysis. First, I do not claim - no one in their right mind would - that social norms could produce the level of discrimination and segregation that existed in the Jim Crow South without support from private violence (and state law). Of course there is no "modern system" that shuns the use of violence but "is able to maintain anything similar to the caste-like structure of Jim Crow." Id. at Iroo. The answer to Professor Epstein's challenge "[w] hy would ... boycotters have ... to resort to violence if vilification" were available, id. at rro3 - is simply that violence secures a higher level of compliance with group norms than vilification alone. But that discrimination will be lower without violence does not, as Professor Epstein assumes, mean that discrimination will cease to exist. See supra pp. 1060-63; infra pp. I068-7I (explaining how subtle forms of discrimination have replaced overt forms). Professor Epstein does not seriously challenge Part I's conclusion that withholding esteem works to induce material sacrifices for group welfare. (Although he argues that some successful civil rights boycotts used violence, see Epstein, supra, at IIo3, he appears to concede that others did not, see id. at Iro4-05.) Thus, social ostracism is, to use Professor Epstein's term, a "stick." Id. at I093. Whether or not status punishments constitute what he means by "coercion," id. at rog2 n.22, the evidence shows they can deter free-riding.

Second, Professor Epstein assumes without explanation that violence is no longer relevant to discriminatory social norms. He optimistically claims that "[e]ven if Title VII were repealed tomorrow, . . . [p]rivate violence by anyone against anyone else would still be sternly prohibited." Id. at rog9. But whether stern prohibitions, evenly enforced, will actually preclude violence and violent threats that support social norms is an empirical question. Not only does racial violence persist today despite legal prohibitions, see infra note 296 , but, more generally, history shows that "no state has been able to prevent [the use of] violence to enforce rules of behavior." ELLICKson, supra note 76 , at 140 n.9. When violence is an option, the threat of violence also enforces norms. See id. at 213; see also id. at 58-59, 215-218 (describing violent self-help by ranchers in Shasta County, California); SALLy E. MERRY, URBAN DANGER I78-86 (I98I) (listing examples of violence or threats of violence as ways of managing danger within a neighborhood); Donald Black, Crime as Social Control, 48 AM. Soc. REv. 34, 42 (1983) (developing a sociological theory of crimes of self-help).

244 Cf. EPSTEIN, supra note II6, at 29-3I (arguing that discrimination by a large majority need not harm a minority if sufficient opportunities among non-discriminators will remain for members of the minority).

245 See J. Mark Ramseyer \& Minoru Nakazato, The Rational Litigant: Settlement Amounts and Verdict Rates in Japan, I8 J. LEGAL STUD. 263, 286-87 (I989). 
Akerlof responds to these arguments with a simple point that depends merely on the existence of transaction costs. ${ }^{246}$ Suppose there are search costs for firms seeking buyers or sellers; because of imperfect information about the existence and reputation of buyers and sellers, firms cannot instantly replace existing trading partners but must incur costs inversely proportional to the number of potential trading partners in the relevant geographic market.247 Under these circumstances, assuming that there are any parties who will boycott "innovators" (those who violate discriminatory norms), the innovators necessarily incur higher search costs in finding trading partners. ${ }^{248}$ Thus, each boycotter raises the likely search costs the innovator will incur before locating a trading partner. ${ }^{249}$ Further, when the innovator locates a non-boycotter, its higher search costs will place it "in a weaker bargaining position, since the cost of failing to make a trade is greater to [it] than to noninnovators."250 If the costs of innovation are higher than the benefits, the discriminatory norm will be stable in a competitive market. ${ }^{251}$

There are, however, weaknesses in Akerlof's explanation. First, Akerlof simply posits that some discriminators will boycott those who fail to follow the discriminatory norm. He offers no explanation of why these boycotters are willing to bear such costs. ${ }^{252}$ The status-pro-

246 See Akerlof, supra note II 7 , at 266.

247 This assumption is supported by relational contracts literature, which claims that firms in ongoing relationships acquire special knowledge about each other. See, e.g., Goetz \& Scott, supra note 17, at Iroo-or; Oliver E. Williamson, Transaction-Cost Economics: The Governance of Contractual Relations, 22 J.L. \& ECON. 233, 240-42 (1979).

248 See Akerlof, supra note II7, at 266-67 (relying on the search model of Peter A. Diamond, Aggregate Demand Management in Search Equilibrium, 90 J. POL. ECON. 881, 882-86 (1982)).

249 Professor Epstein makes two arguments against this analysis. First, he says that it "assumes that boycotters keep their intentions secret." Epstein, supra note 243, at rror. To the contrary, Akerlof assumes merely that there are search costs so that, for a given time period, the probability of finding a trading partner is less than one and varies with the number of traders in the relevant geographic area. See Akerlof, supra note 117, at 269. Consequently, it does not matter if boycotters are instantly recognized as such; when the density of traders in the area falls because some are boycotters, the time (and cost) required for searching necessarily increases.

Second, Professor Epstein suggests that innovators can publicly identify themselves as willing to deal with targets of discrimination and that they can do so "without fear of coercive retaliation." Epstein, supra note 243, at 1 ro2. Even if there is no violence, however, Akerlof demonstrates that it will not pay to innovate if sufficient numbers of traders are willing to boycott innovators. In the employment setting, for example, an innovating employer may lose valuable customers or employees. The analysis of Part I further suggests that the employer may lose the approval of fellow members of his social groups. If these costs outweigh the benefits, advertising oneself as a norm violator will merely ensure a negative return.

250 Akerlof, supra note 117 , at 274 .

251 See id. at 268 ("[U]nlike Becker's model, there is no excess profit to be made by entrepreneurs with no taste for discrimination. And entrepreneurs with a low taste for discrimination cannot profitably purchase the capital of those with a high taste for discrimination.").

252 See Jennifer Roback, Racism as Rent Seeking, 27 ECON. INQUIRY 661, 670 (r989) (explaining that Akerlof's model assumes that "the sanctions are costless to the individual imposing them"). Roback offers a model of racial norm enforcement: individuals "gain utility from con- 
duction model does offer such an explanation. The model shows how individuals gain from adhering to and enforcing certain norms, why the kind of norms individuals benefit from enforcing include norms of discrimination, and why the groups for which this process is frequently employed are racial groups. As I argued above, ${ }^{253}$ individuals within racial groups benefit from raising the status of their shared traits. One means of contributing to one's racial status is by subordinating members of other races. With sufficient overlap between racial and socially connected groups, whites have a status benefit to exploit and the cooperative means to exploit it. ${ }^{254}$

Consider, however, a second possible weakness in Akerlof's model. A simple caste society is an appropriate starting point, but American society is more complex. Unquestionably, a norm exists against racial discrimination (or at least against certain forms of racial discrimination), and some whites, as well as blacks, boycott those who overtly discriminate. Given this reality, one might reject the Akerlof caste model.

Yet, even with blacks and some whites "counter-boycotting" discriminators, the equilibrium may entail significant discrimination. Discriminators will bear a cost when targeted for a counter-boycott (or other sanction), but unless that cost exceeds the cost that discriminators create for non-discriminators, it will pay to continue discriminating. The relative costs depend largely on the relative size and economic power of the two groups. Because whites constitute a large majority and possess disproportionate wealth, the costs from white boycotts is likely to exceed the costs from black counter-boycotts. At some point, the participation by a sufficient number of whites in the counter-boycott would tip the balance the other way, but this outcome seems unlikely. First, one cannot infer from the fact that opponents of discrimination are more vocal today - when discrimination in various forms is illegal - that white opponents of discrimination exceed supporters. Second, those who rely on the power of white counter-boycotts rely on the force of moral principle (or altruism) to overcome the selfish force of status production. Under existing theory, selfishness is thought to undermine discrimination. But given the status productiv-

forming to [a] norm themselves," and "from knowing that other people are conforming to the norm. The utility gain may be a gain in pure psychic income, if, for example, employers gain satisfaction from knowing that blacks are being kept properly 'in their place."' Id. at 665 (footnote omitted). Her model thus describes a benefit to boycotters to offset the costs of the boycott. But Roback merely posits that such gains exist. She does not explain why people would "gain utility" from conforming to or observing other people conform to a norm.

253 See supra p. I045.

254 See supra pp. I046-48. 
ity of discrimination, the power of selfishness suggests the more pessimistic outcome. ${ }^{255}$

One might object that discriminatory norms do not exist if any whites are willing to act against them. That some whites will boycott discriminators merely reflects, however, the fact that American whites do not constitute a single group. "Whites" include various ethnic, religious, political, regional, and class subgroups. How much a particular subgroup invests in subordination as a means of producing status will depend on what its various status options are. Low-status whites have fewer options and tend to discriminate more than high-status whites. $^{256}$ Further, white condemnation of the blatant racial discrimination common in an earlier era is consistent with a more subtle discriminatory norm. Subordination works only as long as one can deny that one is acting for the purpose of producing status. ${ }^{257}$ Whites are less able to deny this function of racial derogation now than in the past; consequently, overt discrimination is no longer as productive of status as it once was. Just as a "nouveau riche" may undermine her own status by engaging in ostentatious and wasteful consumption, a "redneck" or bigot undermines her own status by expressing contempt solely on the basis of race. But, there is still status in wealth if one displays it more deftly, with the appearance of not calculating to make a display. Likewise, there is status to be gained from race discrimination of a more subtle form, especially when one can plausibly deplore its more flagrant manifestations. ${ }^{258}$

255 Professor Epstein says I neglect how the mechanism of intra-group esteem allocation makes forces opposing discrimination more tenacious. See Epstein, supra note 243, at 1 106. To the contrary, I pointed out that the mechanism is necessary to explain the behavior of participants in the civil rights movement that produced Title VII, behavior that economic critics of Title VII ironically - have never addressed. See supra p. ror8. Opposition to discrimination is more tenacious than was previously understood only because previous economic models could not explain why any opposition existed. Notwithstanding this tenacity, there is no reason to suppose that less populous and poorer groups can completely eliminate subordination by the dominant group. That opponents of discrimination sometimes succeed in using esteem allocation to engage in counterboycotts and other defensive measures is precisely the reason $I$ argue that race discrimination is a market failure. See infra pp. 1074-78. Unless one side has such an overwhelming advantage that the other forgoes all competition for status, the endless cycle of investing and counter-investing in zero-sum status production is inefficient.

256 See supra notes 206-2 10 and accompanying text.

257 See supra pp. 1032, 1060-62.

258 I do not refer to highly contested definitions of ultra-subtle discrimination. In American society, discrimination is sufficiently subtle if it refrains from overt. reliance on skin color alone. See, e.g., Samuel L. Gaertner \& John F. Dovidio, The Aversive Form of Racism, in Prejudice, Discrimination, AND RACisM 6I, 77-78, 84-86 (John F. Dovidio \& Samuel L. Gaertner eds., 1986); Joleen Kirschenman \& Kathryn M. Neckerman, "We'd Love to Hire Them, But . ..": The Meaning of Race for Employers, in THE URBAN UNDERCLASS 203, 230-31 (Christopher Jencks \& Paul E. Peterson eds., I99I). For example, a white employer may consider hiring a black worker if, but only if, she stands in stark contrast to all the stereotypes the employer holds of blacks. The employer could genuinely espouse a belief in equal opportunity, but also believe blacks are frequently (but not inherently) indolent, obtuse, or quarrelsome. Such an employer might parade 
One might nevertheless assert that there are significant numbers of whites who oppose even subtle forms of discrimination. One interpretation of this behavior is that high-status whites who condemn lowstatus whites for their discrimination may gain more by distinguishing themselves from other whites than by investing in the subordination of blacks or other minorities. In fact, certain classes of whites may enjoy free-riding on the status that other whites secure and then further increase their status by subordinating those whites for being discriminatory. A second, more sanguine interpretation begins with Ellickson's claim that norms tend to be efficient, at least from the perspective of the group in which they arise. ${ }^{259}$ Ellickson does not discuss norms that span a group as large as an entire society, but a weaker concern for the esteem of strangers might give rise to norms between strangers. ${ }^{260}$ If a weak counter-norm arises against discrimination, perhaps it is because discrimination is inefficient ${ }^{261}$ from the perspective of the entire society. But because the norm arises at a different and more diffuse level, it can exist alongside more powerful discriminatory norms that arise within or between socially connected groups. ${ }^{262}$

Becker's model does not contemplate the existence of discriminatory social norms. Thus, I cannot be certain how he would respond to the claim I make here. But Robert Cooter, who embraces Becker's prediction that competition will drive out discrimination, does consider social norms. ${ }^{263}$ Cooter argues that the proper economic model for discrimination is that of a cartel and that during the Jim Crow era, southern whites advanced their material ends by using law to gain monopoly power in various markets. ${ }^{264}$ Like all cartels, whites faced

her decision to hire a black worker who is manifestly none of those things to prove her belief in equality, but nonetheless think that any blacks who are not model employees fall into one of the negative categories.

Thus, modern discrimination is less derogatory, and therefore less productive of status, than it used to be. But that is no reason to assume that the discriminatory norm must be unraveling. There is, after all, less material cost associated with employing such a norm, since it permits the most materially beneficial trades with blacks (like hiring the manifestly qualified black), refusal of which would be branded as racist. It is thus easier to understand how norms like "never take a chance on a black" or "all things being equal, hire the white" could survive market competition. The status benefit is less than with overt discrimination, but so is the material cost.

259 See Ellickson, supra note 76, at 167.

260 See ElSTER, supra note II, at III; Cooter, supra note 83 , at $230 \mathrm{n} .48$. Both believe there are norms that arise among strangers, although, as Cooter notes, the process by which this occurs "requires explaining." $I d$. at 23 I n.48.

261 I make this argument below at pp. I074-78.

262 The analogy to conspicuous consumption may again be helpful. Existing norms may condemn especially ostentatious consumption because such behavior is inefficient, yet because these norms arise essentially between strangers, they are weak and do not deter more subtle forms of consumption, which are more easily rationalized as something other than conspicuous consumption. See MicAdams, supra note 59, at 42-44, 79-80.

263 See Cooter, supra note 196 , at 166.

264 See id. at $153,155-156$. Thus, Cooter seems to view discrimination as a productive activity, but one productive of material ends. 
the inherent problem of instability - that is, the incentive for each member to cheat. Cooter agrees that discriminatory social norms countered the incentives to free-ride, but asserts that the effectiveness of the norms probably depended on their being supported by Jim Crow legislation. ${ }^{265}$ Thus, Cooter expresses the conventional economic skepticism that the norms that supported the white "cartel" could survive absent such legal restrictions. The material incentives in an unfettered market, in his view, provide a strong lure for individuals to defect from the group enterprise.

The theory of intra-group cooperation and inter-group conflict offers a reason for thinking otherwise. Cooter's skepticism about the independent strength of social norms would be well-founded if the only ends that individuals seek are material. Indeed, I argued previously that social norms add nothing to our understanding of cooperation beyond what can be explained by reciprocity unless people value the esteem of others as an end in itself. ${ }^{266}$ Therefore Cooter's argument might be right if the only purpose of the white cartel were to advance the material ends of whites and the only means of inducing cooperation were material rewards. The whole thrust of the statusproduction model, however, is that the cartel-like behavior of whites serves to maximize the non-material end of status production (the cartel seeks to monopolize social status) and that the cartel employs the non-material means of intra-group status rewards and punishments. If this fundamental point is right, then social norms can support discrimination notwithstanding market competition.

Nevertheless, Cooter's basic insight is quite helpful. Whites do act like a cartel. But whites are more accurately described as the subset of cartels that Posner calls "guilds," that is, cartels with "social cohesiveness." 267 Based on a morality emphasizing loyalty and conformity, these guilds have an "ideology" - a set of beliefs that serves to inhibit free-riding ${ }^{268}$ - specifically that blacks tend to be inferior, that whites should not interact with blacks in certain ways, and that whites must "stick together." Posner contends that farmers and lawyers - very large industrial groups - manage to cooperate in legislative lobbying efforts despite incentives to free-ride. ${ }^{269}$ Racial groups may similarly succeed. For reasons explained above, the more observable the trait

265 See id. at 154 (citing Jennifer Roback, Racism as Rent Seeking, 27 Econ. INQUIRY 661 (1989)).

266 See supra pp. 1027-29.

267 Posner, supra note 222, at ro.

268 See id. at Ir. Posner also expresses doubt that ideology by itself is sufficient for guilds to survive and argues that government restrictions on competition are essential. See id. at 8 (noting that guilds typically have government-granted power to exclude competitors because "prohibiting entry is necessary if the guild is to have supracompetitive profits"). Posner, like Cooter, also considers only guilds whose ends and means are material.

269 See id. at I9. 
that links a group of people, the more status members have to gain by cooperating and the greater the reason to expect such groups to become socially connected as a means of achieving cooperation. Given that race is more observable than these industrial affinities, there is reason to believe racial groups can better succeed in overcoming their collective action problems despite their large size. ${ }^{270}$

Consider, then, a new economic analogy for race discrimination: not transportation costs, but an analogy to the acquisition of a public reputation. An entrepreneur donates a large sum of money to a local museum, or a corporate president agrees to sponsor a marathon. No doubt, the economically inclined theorist would assert that such behavior occurs not because it serves an individual's "taste" for fame, but because it produces greater profits for entrepreneurs and firms by bolstering their reputation or name recognition. I suspect the main force behind this view, however, is nothing as contingent as empirical data on the profitability of such donations, but an inference that economic actors would not give money away unless it was productive to do so. I merely argue for a similar inference with respect to race discrimination. Discrimination exists because it is productive for its practitioners.

(b) Reciprocity as a Basis for Market Discrimination. - There is a second reason to believe that race discrimination will persist in the face of market competition. Becker's theory does not argue that market competition erodes social discrimination. Yet because social interaction facilitates more commercial reciprocity, social discrimination may cause persistent "market" discrimination. . $^{27}$

According to Axelrod's analysis of iterated prisoner's dilemmas, it often pays to seek cooperation through a reciprocal strategy such as tit-for-tat when there is sufficient likelihood of future interaction with another. ${ }^{272}$ Axelrod emphasizes that the more likely future interactions are, the more likely it is that those who employ reciprocal strategies will prosper. Thus, to increase the prospects of cooperation with a particular individual, Axelrod advises (consciously) increasing the durability and frequency of interactions with that individual. ${ }^{273}$ One time-honored means of implementing Axelrod's strategy is to pursue

270 An example of political organizing by whites is the Citizens' Council, which operated in various southern states in the I950S and Ig60s in opposition to integration. "By the second anniversary of the public school decisions . . . 'protective societies' accounted for a considerable portion of the energies of perhaps as many as 250,000 to 300,000 people from virtually every station of southern life. ... [N]one was more powerful than the Citizens' Council ...." McMnLEN, supra note 229, at II.

271 Many commentators have decried the role of the "old-boy network" in perpetuating discrimination against women and minorities. See, e.g., Michael M. Burns, The Exclusion of Women From Influential Men's Clubs: The Inner Sanctum and the Myth of Full Equality, 18 HARV. C.R.C.L. L. REV. 32I, 322-23 (1983).

272 See AXELroD, supra note $\mathrm{r}_{3}$, at $\mathrm{I}_{3}-\mathrm{r}_{4}, 59$.

273 See id. at 126-32. 
social interaction with the group of individuals with whom one wishes to cooperate. When prospective business partners eat, talk, or play together, they are not merely acquiring information about each other. Social interaction also supports reciprocity; by joining a social group, one increases the likelihood of future interaction with members of the group. Most important, social interactions may themselves be relatively inexpensive but might increase the chance of cooperation's emerging in a business or market setting, where the benefits of cooperation are greater. Joining a country club, a "businessman's" club, or a particular neighborhood may "lock" one into a particular social group, raising one's ability to cooperate with members in non-social settings. ${ }^{274}$

We can now understand more fully the power of discriminatory norms. Even in the absence of a social norm that restrains market trading with other racial groups, social norms could significantly impede such trades. A norm limited to preventing social contacts with members of another race is sufficient to harm such members economically. Since social contacts affect the probability of reciprocity, the absence of such contacts places the isolated individual or the disfavored group at a comparative disadvantage in economic trades. Consequently, norm-based discrimination in one setting, such as social clubs or housing, may cause discrimination in other settings, such as business or employment. Social clubs that exclude women and minorities thus cause them more harm than simply denying them information about, and the chance to become known to, market players. They deny them the opportunity to make reciprocity work. ${ }^{275}$

(c) The Power of Esteem-Producing Racial Biases. - A final factor that contributes to the persistence of discrimination is racially biased beliefs or stereotypes. As noted above, discriminatory norms invoke rationalization mechanisms; discriminators prefer to have reasons for discriminating other than a bare interest in status produc-

274 See Burns, supra note 271 , at 325-34.

275 Epstein agrees that reciprocity prevents the market from eliminating discrimination, but argues that it is efficient that such discrimination remain because members of a particular racial or ethnic group may be able to elicit greater cooperation from members of their own group than from non-members. For single-race firms:

The party who cheats at work now knows that he faces stricter sanctions, given the strong

likelihood that the information will be brought home to him at play, at church, or in other business and social settings. The complex network of human interactions thus induces persons to honor their deals.

EPSTEIN, supra note 116 , at $70 ; c f$. Landa, supra note 177 , at $36 \mathrm{I}-62$ (arguing that socially and ethnically homogeneous trading groups have a comparative advantage in economies without reliable legal infrastructure to enforce contracts). Whether such hiring discrimination is actually efficient depends, however, on why the underlying segregation - "at play, at church, or in other business and social settings" - exists. Epstein is correct to note that, regardless of the reasons for the underlying segregation, this form of discrimination will persist: for any particular firm, cooperation is easier to achieve among employees who socialize together. 
tion. ${ }^{276}$ Indeed, because status production is inconsistent with an overt strategy of subordination, it is important that discriminators have an explanation - an "ideology" - apart from status production. ${ }^{277}$ Such an explanation can most easily take the form of negative stereotypes - that the failure of blacks to succeed is their own fault, due to their own shortcomings in ability, integrity, or dependability: This ideology buttresses discriminatory norms. Whatever the social cost of violating the norm, biased evaluations of blacks make it appear that the material benefits of norm violation are less than they are. Self-deception prevents cheating that would undermine the cartel.

Indeed, even if there were no discriminatory social norms, ideologically based racial stereotypes might sustain a stable level of discrimination. One might argue, to the contrary, that absent norms, market competition would discipline whites whose evaluations of blacks were biased. If some white employers fail to perceive black workers accurately, for example, they will lose a competitive advantage to more discerning whites. ${ }^{278}$ Yet there is one condition under which stereotypes alone will sustain discrimination - when the material costs of one's miscalculation is zero. In the employment setting, for example, the employer may believe in some cases that the applicants are essentially "tied," that is, they appear to have equal marginal productivities. ${ }^{279}$ A white employer would suffer no harm from the decision to hire a white applicant who was tied with a black applicant. Of course, given the white employer's ideology, the employer may not actually perceive the two candidates as being equal, but rather will think that the white candidate is better. The point, however, is that there will be no market correction for such a perception; having white job applicants win all "ties" is a market equilibrium. The question remains how frequently such ties occur in the real world - an interesting empirical question that I, like opponents of Title VII, ${ }^{280}$ leave to be answered by others. I simply note that, if such ties were frequent, stereotyping could itself add to the persistence of race discrimination.

In sum, the status-production model provides three reasons to suppose that race discrimination will survive market competition: the power of discriminatory social norms; the existence of reciprocity be-

276 See supra note I10 and accompanying text.

277 See supra pp. 1060-62.

278 See BECKER, supra note II4, at 39-42; see also Cooter, supra note I96, at I6o ("Competition can teach a sharp lesson to businesses that rely upon false signals.").

279 Although marginal productivities may vary continuously so that actual ties are extremely rare, an employer will invest only limited resources into determining the productivity of job applicants. If employers invest only enough to place applicants in one of a few ability categories, then ties could be common.

$280 \mathrm{By}$ ignoring the issue, they implicitly assume that ties never occur. See, e.g., EPSTEIN, supra note $I 16$, at $4 \mathrm{I}-44$. 
tween whites; and, under certain circumstances, the effect of esteemproducing racial biases.

2. The Efficiency of Anti-Discrimination Laws - Many legal economists have contended that federal anti-discrimination laws are efficient only to the extent that they nullify state laws mandating discrimination. ${ }^{281}$ These theorists view such laws as inefficient when they prohibit private discrimination because their only function is to frustrate discriminatory preferences. But the new descriptive theory I propose requires a rethinking of this normative claim. The statusproduction model views anti-discrimination laws as potentially correcting a market failure in which individuals invest in essentially confiscatory behavior. That discrimination is a market failure would not itself prove that government action is desirable. We must consider whether the regulation can correct the failure and whether the benefits of such intervention exceed the costs.

(a) Discrimination as Market Failure: The Theft Analogy.Welfare economics provides a justification for laws that prohibit theft (and other forms of force and fraud) that is not dependent on discounting the gains to the thief (or other criminals). 282 Even assuming that the transfer accomplished by theft itself causes no wealth loss, because the thief gains what the owner loses, ${ }^{283}$ a system that permits theft "results in a very substantial diversion of resources to fields where they essentially offset each other, and produce no positive product." ${ }^{284}$ In other words, absent laws against theft, individuals must expend resources merely to protect their property from seizure. They will also forgo certain wealth-creating activities to protect what they already have and because it may be too costly to protect some forms of wealth from theft. In response, the thief invests in gaining tools and knowledge to circumvent anti-theft practices and technology. These dynamic reactions to the risk of theft result in deadweight losses

281 See sources cited supra note Irg. But see Donohue, Prohibiting Sex Discrimination, supra note I20, at 1347-48; Donohue, Title VII, supra note 120, at I423-3I.

282 See, e.g., Fred S. McChesney, Boxed In: Economists and Benefits From Crime, I3 INT'L REv. L. \& ECON. 225, 227-28 (I993); Richard A. Posner, An Economic Theory of the Criminal Law, 85 CoLum. L. Rev. II93, Irg6, I198 (1985); Gordon Tullock, The Welfare Costs of Tariffs, Monopolies and Theft, 5 W. EcoN. J. 224, 228-3I (1967).

283 One might argue that the transfer often increases wealth because the thief gains more than the owner loses. Yet because economics measures value by willingness to pay, the opposite is likely to be the case. When transaction costs are low, prohibiting theft still permits property transfers through voluntary market exchange. The only transfers prevented by criminalizing theft are, therefore, those in which the thief is not willing to pay the owner enough to induce a voluntary exchange - where, in other words, the thief "values" the good as much as or less than the owner. See POSNer, supra note 3, at 208 \& n.3; Posner, supra note 282, at IIg6. Preventing transfers when the thief values the good less than the owner does is efficient. Economists do not, however, rely on this argument as much as the one in the text, perhaps because they recognize some strength in the claim that utility is often maximized by inefficient larcenous transfers from "haves" to "have-nots." See, e.g., Posner, supra note 282, at Irg6 n.9.

284 Tullock, supra note 282 , at $23 \mathrm{x}$. 
to society. Less is produced, and part of what is produced (burglar alarms and burglars' tools) provides no greater satisfaction of an individual's preferences, but merely helps the individual to retain or confiscate goods that will satisfy preferences. The net effect is to decrease wealth. The same argument applies for laws against violence. It is, of course, Thomas Hobbes's justification for the state: that the only alternative, the "warre . . . of every man, against every man," is worse. ${ }^{285}$

It follows from the status-production model that a society without discrimination laws permits an unfettered status war of "every group against every group." What is striking about Richard Epstein's Forbidden Grounds, ${ }^{286}$ which argues for the repeal of laws that prohibit employment discrimination, is not so much his controversial claim that the only role of government is to prevent force or fraud, but that he never considers how laws against race discrimination may fall precisely within this libertarian principle. ${ }^{287}$ Status "warfare" may not be as violent as literal combat, but the term is more than just a metaphor. Hobbes identifies competition for honor as one of the three causes of war; he warns that violent conflict results from attempted subordination. ${ }^{288}$ Similarly, Hume warned of the tendency of factions to produce "the fiercest animosities."289 Competition for group status has generated much of America's history of interracial violence, as when whites lynched blacks to preserve their social position ${ }^{290}$ or when blacks retaliated against repeated acts of derogation and dishonor. ${ }^{291}$

Of course, laws prohibit such violence. But even with such laws, unregulated status competition mirrors the inefficiency of a regime without laws prohibiting theft. First, racial status preferences inher-

285 Thomas Hobbes, Levathan 88-89 (Richard Tuck ed., Cambridge Univ. Press I99I) (165I); see also EPSTEIN, supra note II6, at I5-19 (describing Hobbes's argument for prohibitions on force and fraud).

286 EPSTEIN, supra note ir6.

287 Cf. Williams, supra note 178 , at 147 (referring to acts of racism as the "appropriation of psychic property").

288 Hobbes observes:

For every man looketh that his companion should value him, at the same rate he sets upon himselfe: And upon all signes of Contempt, or undervaluing, naturally endeavours, as far as he dares (which amongst them that have no common power to keep them in quiet, is far enough to make them destroy each other), to extort a greater value from his contemners, by dommage; and from others, by the example.

HoBBes, supra note 285, at 88. For a more detailed criticism of Epstein's use of Hobbes in Forbidden Grounds, see Richard H. McAdams, Epstein on His Own Grounds, 3 I SAN DIEGo L.

REV. 24I, 242-49 (I994).

289 HuME, supra note 9 , at 55 .

290 See supra notes $193-195$ and accompanying text.

291 See, e.g., Melvin L. Oliver, James H. Johnson, Jr. \& Walter C. Farrell, Jr., Anatomy of a Rebellion: A Political-Economic Analysis, in READING RodNEy KING: REAdING URBaN UprisING II7, 120-2I (Robert Gooding-Williams ed., 1993). For a personal narrative conveying how disparagement leads to rage, see Williams, cited above in note 178 , at $127-29$. 
ently conflict. 292 Race discrimination exists because members of (at least) one race seek for their group a status position that is incompatible with the position sought by members of one or more other groups. Even when only one group seeks superiority, if the other group seeks equality, the struggle for social status is zero sum. Consequently, the appropriation of status by subordinating behavior is, like theft, a mere wealth transfer; the gain to the discriminator is at least matched by the loss to the victim.293 Second, this form of transfer - using discrimination as a mechanism of subordination - generates extremely high costs. By definition, the discriminator makes a material sacrifice (giving up an otherwise favorable trade or engaging in costly behavior) as a means of lowering the status of the victim. The size of the material sacrifice measures the investment that the discriminator makes in status appropriation. This investment determines the initial cost of the process of racial group status production.

But that is not the whole story. As I noted at the outset of this Part, economic analysis of discrimination strikes many non-economists as barren because it fails to acknowledge the full benefit to its practitioners or the full harm to its victims. The status-production model takes as its central premise that whites gain status by discriminating against blacks. To determine the full extent of the investment in, and therefore the costs of, status competition, we must consider the full range of status defense mechanisms employed by victims of discrimination. Such defense mechanisms include the sometimes desperate reactions of those who live as targets of discrimination. These reactions represent further investment in status production and increase the wastefulness of the unregulated process, much like added investment in theft-protection devices constitute waste in a society without theft laws. Of course, the psychological mechanisms at work are vastly more complex. I will attempt merely a brief summary of the reactions within the framework of the status-production model.

292 See supra p. ro3r.

293 This argument is conservative in that it omits the claim that the loss to blacks exceeds the gain to whites. Following the alternative economic argument against theft, see supra note 283 , one could observe that, like thieves, discriminators do not pay their victims for their coerced gain. Prohibiting discrimination still permits voluntary market transactions in status; the only transfers prevented are ones where whites value their status gain as much as or less than blacks value the status loss. Second, though equating value with willingness to pay is controversial in the context of theft, utilitarian concerns support this efficiency analysis in the context of race discrimination. The argument is that the psychological damage to blacks exceeds the status pleasure for whites. Cf. William H. Grier \& Price M. Cobbs, Black Rage 30-33 (I968) (discussing the psychologically devastating legacy of black subordination); ABRAM KARDINER \& LIONEL, OVESEY, ThE Mark of Oppression: A Psychosoctal Study of the AMErican Negro 379 (195) (emphasizing white psychological gains by describing "the degradation of the Negro's status" during slavery as "the extreme manifestation of the ego perversion of dominance"); Chester M. Pierce, Psychiatric Problems of the Black Minority, in 2 AMERICAN HANDBOoK OF PsYchiatry 512, 513-I8 (Silvano Arieti ed., 2d ed. I974) (suggesting that American society's insistence that "white skin color is superior to black skin color" comes at the expense of black mental health). 
First, enraged victims may respond in kind by attempting to disparage and subordinate the original discriminator. Such behavior may take the form of discrimination, which means the victim also makes a wasteful material sacrifice for the sake of status. ${ }^{294}$ The victim may, however, lack the opportunity or wealth to respond in kind and may seek a cheaper means of disparagement such as an insult. Violence is the extreme form of such an insult; it inflicts the loss of dignity inherent in an intentional deprivation of bodily integrity. Even if an African American counters with some means other than violence, the original subordinator may resort to violence to ensure the effectiveness of the original insult and to counter any responsive insult. ${ }^{295}$ Hobbes identified this escalation over dishonor as a primary source of war.

A second response is to seek to regain status by subordinating someone other than the original discriminator. If whites present too difficult a target, other minority groups may be within reach. Thus, the long and unpleasant history of status competition between minority groups exemplifies a predictable response to subordination. ${ }^{296}$ The original victim may also focus on vulnerable members of her own group, such as women or those of a different economic class. ${ }^{297}$ Evidence suggests, for example, that African Americans discriminate against one another on the basis of the relative lightness or darkness of their skin. ${ }^{298}$ Finally, because the original victim may lack any non-violent means of responding to discrimination, some of what appears to be "senseless violence" among discrimination victims may actually be a rational attempt to produce status by subordinating others.

294 Black separatism necessarily has the consequence of refusing some or all economic trades with whites. But separatism may be intended not as an counter-insult, but as a defensive means of achieving psychological independence from white subordination. See supra note 205.

295 Thus, an initially non-violent subordination provokes a non-violent response, but when the subordinator's efforts are frustrated by the victim's "standing her ground," there may be an escalation to violence. A number of race riots fit this pattern. See generally 9 RACE, LAW, AND AMERICAN History 1700-1990: LyNChing, Racial Violence, and Law passim (Paul Finkelman ed., I992) (illustrating how violence, riots, and lynching supported segregation).

296 See Joe R. FEagin, Racial aNd ETHNic Relations 376 (I978) ("Open and violent interethnic conflict has been a crucial current in American history. Earlier immigrant groups have regularly attempted to subordinate later groups."); see also JACK LEVIN \& JACK MCDEVITT, HATE CRMES I37-48 (I993) (recounting racial clashes between minority groups, especially other minorities versus blacks); ROEDIGER, supra note 163 , at I33-63 (relating the history of conflict between Irish immigrants and African Americans); Sumi K. Cho, Korean Americans vs. African Americans: Conflict and Construction, in READING RODNEY KING: READING URBAN UpRISING, supra note 291, at $196,196-204$ (explaining the sources of discrimination and prejudice between Korean Americans and African Americans). The conflict between the Jewish and African American communities is a timely and obvious example of this problem.

297 Black feminists, for example, have described how women of color have been subordinated not only by white men, but by black men and white women. See, e.g., E. Frances White, Listening to the Voices of Black Feminism, 18 RADICAL AM. 7, II-I7 (1984).

298 See Collins, supra note I28, at 79-82; Dollard, supra note I25, at 68-7I; Kristal B. Zook, Light Skinned-ded Naps, in Making FaCe, Making Soul: Creative and Critical PerSPECTIVES BY WOMEN OF COLOR 85, 85-96 (Gloria Anzaldúa ed., I990). 
The victim's responses are not limited to subordinating others. The victim may also withdraw from competition - by which status is generally determined - by adopting beliefs that such competitions are without merit. When a subordinated subgroup fails according to the prevailing cultural values, its members may decide to reject those values completely. ${ }^{299}$ For example, minorities facing discrimination may decide, rather than be judged by standards of academic or economic success, that education or employment is an overrated "white" value. ${ }^{300}$ Like the processes of rationalization, the belief that academics is unimportant may preserve self-esteem; however, such a belief may prove destructive in the long run because it depresses efficient investment in human capital.

Finally, a victim of subordination may wholeheartedly adopt the beliefs of the subordinators, including those that members of her group are deserving of their low status. Such a response might seem unlikely; however, for some it may be easier to accept a lower status with the belief that such a role is natural and proper than to live out such a role every day believing it is arbitrarily imposed. The result, however, is a form of self-loathing. ${ }^{301}$

In sum, many of the effects of discrimination, well-explored in other disciplines, should be of central concern to an economic assessment of the system of race discrimination. In many cases, these effects represent investments that the victims make in defending their status. Combined with the investments made by the original discriminators, these resources represent the deadweight loss of race discrimination. Consequently, considerable evidence demonstrates that race discrimination is a grossly inefficient market failure. ${ }^{302}$

(b) An Efficiency Argument for Anti-Discrimination Laws. - As with laws against theft, the benefit of prohibiting a form of discrimination is to prevent the wasteful investment of resources in such discrimination. When laws prohibit theft, the primary alternative by which the former thief can make material gains is to engage in lawful, productive activity. The argument for laws that prohibit subordination as a means of acquiring status is exactly parallel: by raising the costs of subordination, such laws induce people to switch to socially productive, or at least socially benign, means of acquiring status (either at an individual or a group level). Subordination is not the

299 See CLARK, supra note 129, at 70 ("The Negro male was, therefore, driven to seek status in ways which seemed . . . antisocial, escapist, [or] socially irresponsible.").

300 See, e.g., Janita Poe, A Black-On-Black Education Barrier, CHI. TRIB., Jan. I, I994, § I, at I.

301 See, e.g., Kenneth B. Clark, Prejudice and Your Child 49-5I (1955).

302 In fact, the very inefficiency of this system may explain the existence of an anti-discrimination norm or counter-norm. Because the counter-norm arises between strangers, however, it is not likely to cancel the effect of stronger discriminatory norms that arise within and between socially connected groups. See supra p. Io6g. 
only means of group status production, and inter-group status production is not the only means of gaining esteem. ${ }^{303}$

A possible distinction from theft, however, is the availability of equally wasteful substitutes to blatant discrimination. A group with a disproportionately large share of political power, economic wealth, and symbols of status will have at its disposal a number of alternative means of subordinating a minority group. Prohibiting one form of subordinating behavior may simply cause a shift to an equally wasteful form of acquiring status. ${ }^{304}$ Such a concern, however, may be overstated. After all, common law larceny initially required a trespass in the taking and thus exempted what we now think of as embezzlement and fraud. ${ }^{305}$ Even though thieves were free to switch to nontrespassory means of confiscation, the initial prohibition was nonetheless efficient. The opportunities remaining were more limited and costly; a complete substitution would not occur. The same argument can be made for prohibiting private discrimination in certain key areas, such as employment and housing. These forms of discrimination probably represent the most productive means of subordination and therefore induce the greatest "investment" by whites. As I previously pointed out, employment discrimination offers for whites a double insult to blacks: not only the insult inherent in shunning someone, but also the consequence of lowering black income in a society that accords status to wealth. Similarly, excluding blacks from neighborhoods is not only a very public symbol of subordination, but also denies them the material benefits of reciprocity that may arise among neighbors. ${ }^{306}$ Effectively prohibiting employment and housing discrimination would deprive whites of their most productive private means of subordination and would thereby lower the resources invested in this wasteful confiscatory activity. 307

Second, anti-discrimination laws may lower the investment in status confiscation by increasing the incidence of "cross-membership." Ceteris paribus, an individual prefers subordinating a group to which

303 People can concentrate, for example, on raising their group status by focusing on the positive achievements of their group rather than by derogation of other groups or by elevating the status of groups whose welfare does not inherently conflict with other groups. Similarly, people can decide to seek increased intra-group esteem through positive achievement or through ways that do not inherently conflict with the preferences of other group members.

304 One might view hate speech in this manner, as potential discriminators attempt to subvert verbally those protected by anti-discrimination laws.

305 See George P. Fletcher, The Metamorphosis of Larceny, 89 HARv. L. Rev. 469,469 n.I, 496 (1976).

306 See supra p. 1072. If blacks are already disproportionately poor in society, partitioning of white and black neighborhoods will harm blacks more than it harms whites.

307 Liability works directly to raise the costs of subordination but also works indirectly. Those who enforce discriminatory norms by threats or the use of low-level violence now find their targets are - given civil liability - harder to intimidate. Norm enforcers could use higher levels of violence, but criminal sanctions more effectively detect and deter such immoderate violence. 
she does not belong to subordinating a group to which she does belong. An individual always bears a cost from subordination of her own group and that cost gives her an incentive to avoid such behavior. ${ }^{308}$ In fact, an individual who is a member of group $A$ and group $B$ might find it in her interest to invest in efforts to prevent members of group $A$ from seeking to subordinate group $B$. Therefore, the more "cross-membership" between two groups, the fewer the resources that will be invested by the two groups in subordinating each other. ${ }^{309}$

Laws forbidding race discrimination may increase the occurrence of cross-membership and thereby undermine the effectiveness of racial subordination as a status strategy. Race has been and remains highly correlated with other demographic factors. ${ }^{310}$ If a white individual lives in an all-white neighborhood, attends an all-white school, works in an all-white firm, worships at an all-white church, belongs to an all-white amateur sports league, and patronizes all-white hobby clubs, she will never face the problem of cross-membership. If, however, anti-discrimination laws were to integrate neighborhoods, schools, firms, and private clubs, more whites would find themselves in a position in which racial minorities belong to some of their groups. Consequently, racial subordination would lower the status of these integrated groups. One response will be for whites to flee the groups that become integrated, but if the costs are too high, as when the law integrates a number of social groups at the same time, the effect might be to lower the effectiveness of racial subordination as a status strategy for many whites. ${ }^{311}$

308 The cost one bears for subordinating one's own group does not completely eliminate this strategy. One may, for example, be willing to raise the status of a group in which one has very high intra-group status at the expense of lowering the status of a group in which one has only average intra-group status - especially if one has few alternative options for producing esteem. Racial minorities who denigrate members of their own race and women who demean other women have made precisely such a choice. See supra notes 298-299 and accompanying text.

309 The corollary is that individuals join groups that do not act to subordinate each other, or leave one of the groups when such a status conflict arises. Yet sometimes the cost of avoiding membership in either of two such groups outweighs the benefits of avoiding the status conflict. In such cases, the individual is less likely to invest in subordination of either group than those who belong only to one of the two groups, and may invest in restraining other members from investing in the subordination strategy.

310 See, e.g., David H. Swinton, The Economic Status of African Americans: "Permanent" Poverty and Inequality, in The State of Black AMerica 1991, at 25, 25-65 (Janet Dewart ed., I99I).

$311 \mathrm{My}$ argument here is not that "contact" between the races decreases prejudice. That claim is the subject of extended discussion and debate. See, e.g., Norman Miller \& Marilynn B. Brewer, The Social Psychology of Desegregation: An Introduction, in Groups IN ConTACT: THE PSYCHOLOGY OF DESEGREGATION, supra note 227, at I, 2-4. To the contrary, the status-production model contemplates that people can obtain status by subordinating those with whom they have frequent contact. My point is that cross-membership makes subordination, by either group against the other, less productive of status. 
Finally, anti-discrimination laws may serve to correct the market failure of discrimination by undermining the credibility of rationalizations for discrimination. Several commentators have noted that the law shapes preferences, and that Title VII and other civil rights laws may have reduced the preference for discrimination. ${ }^{312}$ The statusproduction model explains this evolution not as a change in the taste for discrimination, but as a change in the productive capacity of certain forms of subordination. Individuals who seek status require some rationalization for their behavior. Admitting that one seeks to subordinate others for the sake of status conflicts with obtaining such status. Law affects the credibility of any alternative explanation. Take Posner's example of a guild that survives on an ideology of quality to justify restrictions on competition. ${ }^{313}$ Consider the long-term effect Posner's critique might have on such ideology were it sufficiently publicized. Exposing the naked self-interest behind platitudes of public concern erodes their effectiveness.

Law is more crude than an intellectual critique, yet it is inherently more public, and can carry more weight. When Jim Crow laws mandated certain forms of segregation, whites confidently spoke of segregation as the natural order of things; when the laws forbade segregation, discriminatory whites had a greater difficulty believing their own ideology. Rationalizations can be fragile things; sometimes they require that dissent be held to a minimum. In the South and elsewhere, Title VII constituted a very powerful "dissent," an indication that a large number, perhaps a majority, of Americans no longer believed the explanations of discrimination. If people care about esteem, the law can change behavior merely by signaling on what grounds the majority will henceforth give and withhold esteem.

In sum, law may correct the market failure of discrimination in three ways: by raising the costs and lowering the productive returns of certain forms of subordination; by increasing the racial diversity of socially connected groups, which raises selfish resistance to the subordination strategy; and by symbolizing a consensus that the rationalizations for the subordination strategy are, in fact, mere rationalizations. Whether such laws are efficient depends on the magnitude of these benefits relative to the administrative and opportunity costs of

312 See, e.g., Donohue, Prohibiting Sex Discrimination, supra note 120 , at 1338-39 \& n.6; Posner, Title VII, supra note II9, at 520 . Indeed, surveys suggest a profound decrease in the number of whites who deny the principles of equal opportunity. See supra note 214. See generally Kenneth Dau-Schmidt, Legal Prohibitions as More Than Prices: Preference-Shaping Policies Under the Law, in New and Critical PeRspectives In LAw and Economics (Robin Malloy \& Christopher Braun eds., forthcoming I995) (discussing Title VII as one example of laws that attempt to change "invidious preferences").

313 See supra pp. 1059-60. 
the system that adjudicates discrimination claims. ${ }^{314}$ But under the status-production model, the efficiency question is, like it is for the prohibition of theft, an empirical one; one can no longer simply assert that laws prohibiting satisfaction of discriminatory preferences are presumptively inefficient.

One might inquire about the implications of the status-production model of discrimination for affirmative action. In what may seem like an evasion, I believe the model provides no clear answer for affirmative action, but does reveal the consequential tensions the policy represents. The "cross-membership" effect of anti-discrimination laws provides a theoretical foundation for the claim that affirmative action serves to combat discrimination more effectively than a mere non-discrimination policy. Indeed, the benefit of cross-membership might justify a very aggressive affirmative action program. The utility of integrating social groups by race is not limited by any principle of past wrongful discrimination. The status-production model indicates that we can reduce investment in future status subordination by decreasing racial stratification in society.

Conversely, affirmative action creates a "common fate" for those of the same race and thus raises the salience of race. As critics of affirmative action have claimed, this fact may cause whites to identify themselves more fully with their race. ${ }^{315}$ The status-production model adds this insight: raising the salience of race may increase the return from racial subordination and enhance the power of whites to elicit intragroup cooperation for the remaining avenues of racial subordination. Affirmative action likely has already had this effect, which offsets the positive effects of cross-membership. However difficult it is to ascertain the present net effect, the more important and difficult question is what the future effects will be. Affirmative action has, so far, done little to integrate effectively American society. ${ }^{316}$ Therefore, we have no reason to expect the positive consequences of that policy to have emerged. In the end, the status-production model reveals what I think we knew already: affirmative action is an investment in which we bear certain costs today for the hope of a greater return tomorrow. The model illuminates, but does not resolve, the empirical question of whether the future benefits will outweigh the present costs.

314 See EPSTEIN, supra note II6, at 242-66 (providing a comprehensive description of such costs). For an attempt to measure them, see John J. Donohue III, Advocacy Versus Analysis in Assessing Employment Discrimination Law, 44 STAN. L. REV. 1583, 1599-1603 (1992) (reviewing RICHARD A. EPSTEIN, ForBIDDEN GROUNDS (1992)). Donohue also attempts to calculate the benefits of Title VII, but not along the lines suggested here. See id. at 1603-07.

315 See Terry Eastland, The Case Against Affirmative Action, 34 WM. \& MARY L. REv. 33, 46 (1992); William Van Alstyne, Rites of Passage: Race, the Supreme Court, and the Constitution, 46 U. CHI. L. Rev. 775, 809 (I979).

316 See supra p. 1080. 


\section{ConClusion}

Groups inherently tend to elicit a level of cooperation from their members and to incur a level of conflict with other groups. The cooperation, in fact, facilitates the conflict. Intra-group esteem allocation permits groups to overcome certain collective action problems that would otherwise make conflict impossible. At the same time, the desire for esteem provides a new objective of group conflict - competition over social status.

What I have termed the theory of intra-group cooperation and inter-group conflict is merely the logical extension of three other steps in political and economic theory. First, Hobbes, among others, justified the state as necessary to avoid perpetual conflict in the state of nature; thus the state's role is to facilitate peaceful cooperation. ${ }^{317}$ Second, economists have persuasively contended that certain forms of peaceful cooperation, such as price-fixing, are detrimental to society. Consequently, the government should act in such cases to prevent cooperation. ${ }^{318}$ Third, Ellickson, among others, has written that groups use social norms to solve collective action problems without the centralized coercive power of the state, namely to bring about a cooperative "order without law."319 The next step, I propose, is to recognize that significant instances of this decentralized cooperation will inevitably be socially destructive and, therefore, that government should obstruct these forms of cooperation. Groups inherently tend to use their powers of decentralized cooperation to produce status through the socially wasteful process of subordination. As with cartels, cooperation in such cases is a social threat that justifies state action.

Aside from these general political implications, the theory of intragroup cooperation and inter-group conflict illuminates the complex problem of race discrimination. Status production explains both the historic and contemporary contours of race discrimination far better than the prevailing associational model of discrimination. Understanding race discrimination as a means of producing status helps us explain its tenacity in the face of market competition and reveals, within an economic model, the full costs of the practice of discrimination. The effort to gain status by taking status away from others, and the responsive measures this effort elicits, are socially wasteful in the same way that confiscation of material property is wasteful. The inefficiency in the system of status competition is measured by the investments each group makes in gaining or protecting its status. Prohibiting the more productive forms of investments can reduce the wastefulness of such actions even if it does not eliminate it.

317 See HOBBes supra note 285 , at 88-89.

318 See Ayres, supra note 17 , at 320-22.

319 See Ellickson, supra note 76, at 46, 167-69. 
In criticizing the associational preference model of discrimination, I focused intensively on a single form of discrimination - racial discrimination - and within that category, exclusively on discrimination against African Americans. The points I made in this context, however, apply to other forms of racial and ethnic discrimination. When substantial overlap exists between groups that share publicly observable traits and groups that are socially connected, the theory predicts substantial investment in status production, including the subordination of other groups. With more than two racial and ethnic groups, greater opportunity exists for movement in social position, and there is, therefore, reason to expect greater investment in maintaining or improving status.

\section{$* * * * *$}

Groups matter. Groups form for simple informational reasons, as economics describes in considerable detail: to minimize the transaction costs people incur in the course of satisfying their preferences. ${ }^{320}$ Yet the formation of groups has another consequence. People have a loyalty to groups that goes beyond what serves their narrow pecuniary self-interest. I have sought to explain that solidarity in self-interested terms; doing so requires an expanded understanding of self-interest that includes a powerful desire for esteem and status. Given the ubiquity of groups, this broader social science perspective on their function should prove useful in understanding legal issues beyond racial discrimination. For now, I have argued for a sober appreciation that solidarity for some often means enmity for others.

320 See COASE, supra note 6, at 33-55. Firms lower the transaction costs of production. See id. at 6-7. Chess-clubs lower the transaction costs for people who are looking for a game of chess. 